\title{
Integrated Soil and Crop Management in Organic Agriculture: A Logical Framework to Ensure Food Quality and Human Health?
}

\author{
Leonidas Rempelos ${ }^{1, *}\left(\mathbb{C}\right.$, Marcin Baranski ${ }^{1,2, *} \mathbb{1}$, Juan Wang ${ }^{1,3}$, Timothy N. Adams ${ }^{1,4}$, Kolawole Adebusuyi ${ }^{1,5}$, \\ Jeremy J. Beckman 1,6 , Charlotte J. Brockbank 1,7 , Bradley S. Douglas 1,8, Tianer Feng 1,9, Jem D. Greenway 1,10, \\ Mehmet Gür 1,11®), Eric Iyaremye 1,12, Chi Leong Kong 1,13®), Recep Korkut ${ }^{1,14}{ }^{\circledR}$, Shreiya S. Kumar 1,15, \\ Jonas Kwedibana ${ }^{1,16} \oplus$, Julia Masselos ${ }^{1,17}$, Benedicto N. Mutalemwa ${ }^{1,18}$, Baring S. Nkambule 1,19, \\ Olatunde B. Oduwole ${ }^{1,20}{ }^{(}$, Ayobami Karimot Oladipo ${ }^{1,21}$, Julius O. Olumeh ${ }^{1,22}$, Leticija Petrovic ${ }^{1,23}$, \\ Nina Röhrig ${ }^{1,24} \mathbb{D}^{\mathbb{D}}$, Sarah A. Wyld ${ }^{1,25}$, Luxi Xu ${ }^{1,26}$, Yaqiong Pan ${ }^{27}$, Eleni Chatzidimitriou ${ }^{1,28}$, Hannah Davis ${ }^{1} \mathbb{D}_{\text {, }}$ \\ Amelia Magistrali ${ }^{1} \mathbb{1}$, Enas Sufar ${ }^{1}$, Gultakin Hasanaliyeva ${ }^{1,29}{ }^{\circledR}$, Hassan Habib Hassan Ashra Kalee ${ }^{30}$, \\ Adam Willson ${ }^{31}$, Manisha Thapa ${ }^{31}$, Pip Davenport ${ }^{31}$, Dominika Średnicka-Tober 1,32 ${ }^{\circledR}$, Nikos Volakakis ${ }^{1,33}$, \\ Anthony Watson ${ }^{34}\left(\mathbb{D}\right.$, Chris J. Seal $^{34}\left(\mathbb{1}\right.$, Mark Goltz ${ }^{35}$, Peter Kindersley, Jr. ${ }^{36}$, Per Ole Iversen ${ }^{37}(\mathbb{C}$ \\ and Carlo Leifert ${ }^{1,31,37, *}$
}

check for

updates

Citation: Rempelos, L.; Baranski, M.; Wang, J.; Adams, T.N.; Adebusuyi, K.; Beckman, J.J.; Brockbank, C.J.;

Douglas, B.S.; Feng, T.; Greenway, J.D.; et al. Integrated Soil and Crop

Management in Organic Agriculture:

A Logical Framework to Ensure Food Quality and Human

Health? Agronomy 2021, 11, 2494.

https://doi.org/10.3390/

agronomy11122494

Academic Editor: Milena Petriccione

Received: 31 October 2021

Accepted: 1 December 2021

Published: 8 December 2021

Publisher's Note: MDPI stays neutral with regard to jurisdictional claims in published maps and institutional affiliations.

Copyright: (c) 2021 by the authors. Licensee MDPI, Basel, Switzerland. This article is an open access article distributed under the terms and conditions of the Creative Commons Attribution (CC BY) license (https:/ / creativecommons.org/licenses/by/ $4.0 /)$.
1 Nafferton Ecological Farming Group, Newcastle University, Newcastle upon Tyne NE1 7RU, UK; j.wang28@outlook.com (J.W.); t.adams2613@gmail.com (T.N.A.); kola@biotreeinternational.com (K.A.); jeremy.beckman@gmail.com (J.J.B.); Charlotte.Brockbank@ringtons.co.uk (C.J.B.); bradouga@hotmail.com (B.S.D.); bbellis94@outlook.com (T.F.); jemgreenway@gmail.com (J.D.G.); mehmetgur@tarimorman.gov.tr (M.G.); ericiyaremye298@gmail.com (E.I.); russellkong@gmail.com (C.L.K.); recep.korkut@tarimorman.gov.tr (R.K.); shreiya_shiv@yahoo.com (S.S.K.); jaykaybw05@gmail.com (J.K.); juliamasselos@gmail.com (J.M.); mutalemwaben@yahoo.com (B.N.M.); baringnkambule@yahoo.com (B.S.N.); Oduwole121@gmail.com (O.B.O.); kareemaholadipo@gmail.com (A.K.O.); olumehjulius@gmail.com (J.O.O.); leticijapetrovic@yahoo.com (L.P.); n.roehrig@reading.ac.uk (N.R.); swyld@hotmail.co.uk (S.A.W.); xuluxi509@gmail.com (L.X.); eleni.e.chatzidimitriou@gmail.com (E.C.); hannah.davis@newcastle.ac.uk (H.D.); amelia.magistrali@newcastle.ac.uk (A.M.); enasalkaisi@gmail.com (E.S.);

gultekin.hasanaliyeva@gmail.com (G.H.); dominika_srednicka_tober@sggw.edu.pl (D.Ś.-T.); nvolakakis@gmail.com (N.V.)

2 Laboratory of Neurobiology, Nencki Institute of Experimental Biology, Polish Academy of Sciences, Pasteura 3, 02-093 Warsaw, Poland

3 School of Agriculture and Biology, Shanghai Jiao Tong University, Shanghai 200240, China

Brown and Co. Agricultural Business Consultants, Banbury OX16 0TH, UK

Biotree Cocoa Estate, Clavering House, Clavering Place, Newcastle upon Tyne NE1 3NG, UK

Independent Researcher, Martin Place, Singapore 237990, Singapore

Tea Packing Division, Ringtons Ltd., Newcastle upon Tyne NE6 2YN, UK

8 Economic Planning \& Sustainable Development Division, Ministry of Finance \& Economic Planning, Kingstown VC0120, Saint Vincent and the Grenadines

9 Building Energy Research Center (BERC), HKUST Fok Ying Tung Research Institute, Guangzhou 511458, China

10 Safety, Health Environment (SHEQ) Department, Engie, Airport Business Park, Tinsley, Sheffield S9 1XU, UK

11 Atatürk Soil, Water and Agricultural Meteorology Research Institute, 39060 Kırklareli, Turkey

12 Aid Coordination Department, Japan International Development Agency, Ebenezer House,

Boulevard de 1'Umuganda Kigali, Kigali P.O. Box 7229, Rwanda

13 Urban Mushroom HK, Tuen Mun, Hong Kong 999077, China

14 Erzincan Horticultural Research Institute, Erzincan 24060, Turkey

15 Office of the Prime Minister/Cabinet Office, Fijian Government, Suva P.O. Box 2225, Fiji

16 Easton Organics (Pty) Ltd., Gaborone P.O. Box 100, Botswana

17 Marketing Team, Toggi Hire, 2 Vicentia Quay, London SW11 3GY, UK

18 Research and Agrometeorology Section, Tanzania Meteorological Agency,

Dar es Salaam P.O. Box 3056, Tanzania

19 Crop Production Section, His Majesty's Correctional Services, Bigbend L311, Eswatini

20 PricewaterhouseCoopers, 1115 Ave SW Suite 3100, Calgary, AB T2P 5L3, Canada

21 HEDA Resource Centre, Environmental Justice and Sustainable Development Department, Ikeja 100271, Nigeria

22 Department of Agriculture and Technical Sciences, Lukenya University, Nairobi 00100 , Kenya

23 Public Service Consulting Department, Accenture, 30 Fenchurch Street, London EC3M 3BD, UK 
Pierre et Marie Curie, 94701 Maisons-Alfort, France

29 Department of Sustainable Crop and Food Protection, Faculty of Agriculture, Food and Environmental Sciences, Universita Catollica del Sacro Cuore, I-29122 Piacenza, Italy

30 Field Crops Department, College of Agriculture, Kirkuk University, Kirkuk 52001, Iraq; hassan.habib@uokirkuk.edu.iq

31 SCU Plant Science, Southern Cross University, Military Rd., Lismore, NSW 2480, Australia; adam.willson@scu.edu.au (A.W.); m.thapa.19@student.scu.edu.au (M.T.); pip.davenport@scu.edu.au (P.D.)

32 Institute of Human Nutrition Sciences, Warsaw University of Life Sciences, Nowoursynowska 159c, 02-776 Warsaw, Poland

33 Geokomi plc, Agriculture Consultancy, P.O. Box 21, Sivas-Faistos, GR 70200 Crete, Greece

34 Human Nutrition Research Centre, Public Health Sciences Institute, Newcastle upon Tyne NE2 4HH, UK; anthony.watson@ncl.ac.uk (A.W.); chris.seal@ncl.ac.uk (C.J.S.)

35 TAFE-NSW, Wollongbar, NSW 2477, Australia; mark.goltz@tafensw.edu.au

36 Peter Kindersley plc, 39 Cardigan Street, London SE11 5PF, UK; info@peterkindersley.com

37 Department of Nutrition, IMB, University of Oslo, 0372 Oslo, Norway; p.o.iversen@medisin.uio.no

* Correspondence: leonidas.rempelos@newcastle.ac.uk (L.R.); m.baranski@nencki.edu.pl (M.B.); carlo.leifert@gmail.com (C.L.)

Abstract: The environmental and biodiversity benefits of organic farming are widely recognized, but there is still controversy about the effects of organic production methods on the nutritional composition of food and human health. In the first part of this article therefore, we critically review the evidence that organic farming methods improve the nutritional quality of food crops. Moreover, we summarize our current understanding of how quality gains are linked to the implementation of the "innovations" introduced into conventional crop production during the intensification or "green revolution" of agriculture over the last 100 years. In the second part of the article, we critically review the evidence for the range of health benefits related to organic food consumption. Specifically, we describe and discuss the results from: (i) dietary intervention studies which have found that organic food consumption substantially reduces pesticide exposure in humans and affects feed intake, growth, hormone balances and immune system responsiveness in animal models; (ii) human cohort/epidemiological studies which have reported significant positive associations between organic food consumption and the lower incidence of a range of diseases including obesity, metabolic syndrome, cancer, hypospadias, pre-eclampsia, eczema and middle ear infections in infants; (iii) interactions and trade-offs between diet (e.g., whole-grain, fruit and vegetables and reduced red-meat consumption) and food types (organic versus conventional) concerning public health and future food security. The article also identifies knowledge gaps and highlights the need for (i) longterm, factorial field experiments to understand the relative effects of agronomic and pedoclimatic drivers on crop quality and safety, and (ii) clinical trials and additional human cohort studies to confirm the positive health outcomes linked to organic food consumption. The main conclusions from our review are that there is growing evidence that (i) agricultural intensification has resulted in a reduction in the nutritional quality of food and the sustainability of food production, and (ii) organic farming practices not only improve food quality and human health, but also food security. This is particularly true where current nutritional guidelines (increasing whole-grain, fruit and vegetable products, while reducing red-meat consumption) are implemented.

Keywords: organic farming; conventional farming; food composition; human health; food security; phenolics; antioxidants; mineral micronutrients; cadmium; pesticides; mycotoxins

\section{Introduction}

Over the last 25 years, the demand for and production of organic food has increased rapidly globally [1]. According to the latest statistics, organic land area has grown from 
11 million hectares in 1999 to 72 million ha in 2018, and the organic market value has grown from 15 billion euro in 2000 to 97 billion euro in 2018 [1]. In 2018 there were an estimated 2.8 million organic producers globally, and 108 countries with organic regulations [1]. Demand is driven by consumer perceptions that, compared with intensive conventional farming, organic farming is more sustainable, and delivers environmental, biodiversity, and food quality and safety benefits [1-3].

In many countries, organic farming standards are defined by government laws and regulations [1,4-6]. Organic farming regulations prohibit or restrict the use of many external inputs that are commonly used in conventional farming, primarily because they are (i) nonrenewable resources (e.g., mineral $\mathrm{P}, \mathrm{K}$ and micronutrient fertilizers), (ii) energy intensive to produce (e.g., mineral $\mathrm{N}$ fertilizers, pesticides) and/or (iii) potentially deleterious to the environment and human health (e.g., mineral $\mathrm{N}$ and $\mathrm{P}$ fertilizers, synthetic chemical pesticides, antibiotics, food additives) $[1,5,6]$.

Specifically, organic crop production prohibits the use of all synthetic chemical cropprotection products (including insecticides, acaricides, fungicides, herbicides, plant growth regulators and soil disinfection chemicals) and mineral $\mathrm{N}, \mathrm{KCl}$ and superphosphate fertilizers [4-6]. Instead, weed, pest and disease control in organic farming is based on preventative and non-chemical crop protection methods, such as the use of (i) diverse crop rotations, (ii) more resistant/tolerant varieties, (iii) mechanical weeding, and (iv) biological disease and pest control products. Organic crop production standards do, however, permit the use of certain plant (e.g., pyrethrum) or microbial extracts (e.g., spinosad) and/or mineral-based (e.g., $\mathrm{Cu}$ and S) crop-protection products, but it is recommended that these are only used as a last resort [4-6]. Organic farming standards prescribe regular inputs of organic fertilizers (e.g., manure and composts) and the use of legume crops in rotation (to increase N-levels and balance N:P ratios in the soil). They also allow the restricted use of raw phosphate, potassium sulphate and mineral micronutrient fertilizers if shown to be necessary by soil or plant analyses $[4,6]$. As a result, organic and conventional crop production protocols differ substantially in (i) the type of crop protection protocols used, (ii) the types and quantities of organic and mineral fertilizers applied, and (iii) increasingly, the types of crop varieties used for production [7-13].

The main aim of this review article is to describe and critically discuss the current information on how integrated soil fertility and crop health management practices used in organic farming may affect the nutritional quality and safety of food crops and human health/wellbeing. The interactions between agronomic practices permitted and prohibited/restricted in organic farming systems and crop health and quality parameters are described using a revised "Logical Framework for organic crop production systems" (Figure 1). Our review is subdivided into three main parts. In part one, we describe the logical framework for organic crop production and the current understanding of how the contrasting agronomic regimes used in organic and conventional production lead to differences in (i) crop resistance and health, and (ii) nutritionally relevant crop-composition profiles. In part two, we review the currently available evidence for physiological and health impacts from organic food consumption. In part three-the conclusion-we describe the main knowledge gaps and strengths of the currently available scientific evidence supporting the main hypothesis/philosophy of organic farming, which is that "healthy soils generate healthy crops and thereby healthy livestock and humans" [6].

\section{Effect of Agronomic Practices on Crop Yield, Health and Nutritional Quality}

Systematic reviews/meta-analyses and long-term field experiments have found that yields in organic farming systems are between 10 and $25 \%$ lower than the yield in intensive conventional production systems [14-21]. However, the results from a long-term farming system comparison in the Netherlands suggest that the yield gap between organic and conventional farming diminishes over time, and that this coincides with higher nutrientuse efficiency and "spatial stability" in the organic system [17]. One recent meta-analysis also concluded that the inclusion of diversification practices in organic systems can reduce 
the yield gap [18]. It is interesting to note that current crop yields in organic farming are similar to conventional crop yields in Europe in the 1980s and 1990s, when mineral NPK fertilizer inputs were higher, and pesticide inputs were at similar levels to those currently used in conventional crop production in Europe [22,23].

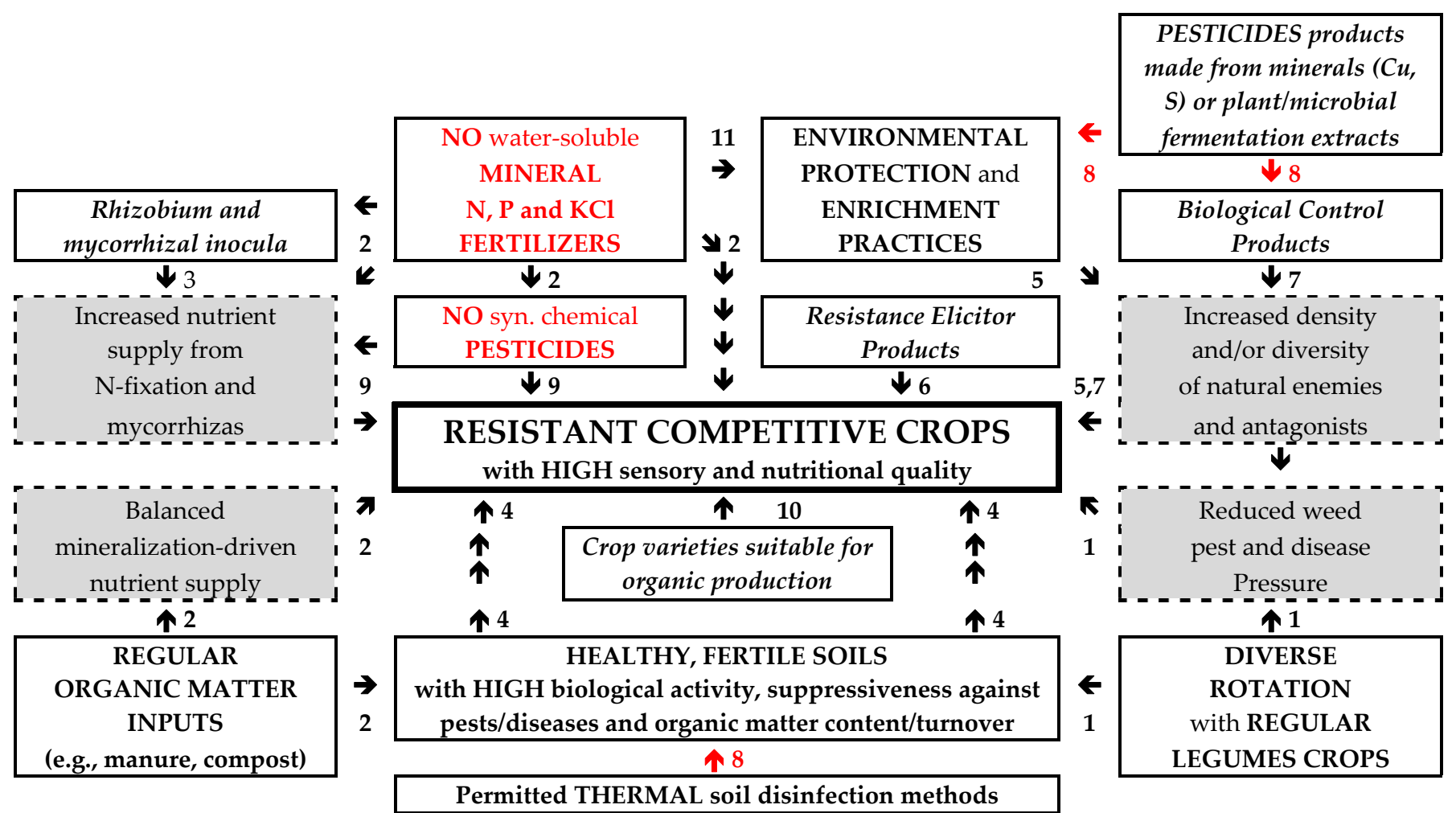

Figure 1. Logical Framework for organic crop-production systems (adapted from Leifert et al. [24]). Black text in white background describes inputs and practices permitted in organic farming; black text in boxes with grey background surrounded by dotted lines indicates an agronomically desirable effect of permitted inputs and practices or the non-use of agrochemicals; black text in boxes with white background surrounded by solid lines describes agronomic practices permitted and/or recommended in organic farming; red text in white background boxes surrounded by solid black lines describes inputs that are prohibited in organic farming. Black arrows indicate desirable impacts; red arrows indicate undesirable impacts. 1, see also Section 2.1; 2, see also Sections 2.2.1 and 2.2.2; 3, see also Section 2.2.3; 4 , see also Section 2.3.1; 5, see also Section 2.3.2; $\mathbf{6}$, see also Section 2.3.3; , see also Section 2.3.4; 8, see also Section 2.3.5; $\mathbf{9}$, see also Section 2.3.6; 10, see also Section 2.4 .

The evidence for food quality and safety gains resulting from the organic production described in this review should therefore be considered in the context of (i) the lower yields, and (ii) reduced reliance on non-renewable and increasingly scarce resources in organic farming, compared with conventional farming systems [1,6,24].

Figure 1 describes the logical framework for organic crop production systems, which is designed to deliver resistant, competitive crops with high sensory and nutritional qualities, without the use of water-soluble, mineral $\mathrm{N}, \mathrm{P}$ and $\mathrm{KCl}$ fertilizers and synthetic chemical pesticides. The main components of organic production systems and their effects on crop health and nutritional quality are described in separate sections below. Specifically, this includes sections on: (i) crop rotation designs (Section 2.1); (ii) fertilization regimes (Section 2.2); (iii) crop protection (Section 2.3); (iv) crop breeding and selection (Section 2.4). In addition, Section 2.5 describes the impact of confounding effects of pedoclimatic background conditions on crop quality parameters to explain the considerable variation and sometimes conflicting results reported in studies comparing the nutritional composition of organic and conventional crops. 


\subsection{Crop Rotation Design}

Historically, organic farms were mainly mixed farms with legume-rich, rotational and/or permanent grassland that was used for grazing and/or conserved forage production $[6,25,26]$. The 2-to-5-year ley phase substantially reduces weed pressure that builds-up while annual food crops are grown in the rotation, with weed pressure being particularly high after field vegetable crops [6,25-29]. Stockless arable and horticultural crop production systems also have mixed grass/legume or pure legume leys in the rotations, but grassland management focuses primarily on optimizing N-balances and soil fertility for subsequent annual cash crops [30,31]. It is interesting to note that stockless, conventional arable farms with persistent and/or herbicide-resistant black-grass problems have started to re-introduced grass-leys and grazing livestock to control black-grass (Alopecurus myosuroides Huds.) in their rotations [29]. Catch- and under-sown cover crops are also more widely used in organic crop rotations; although they are mainly included to prevent nutrient losses, they can also contribute to weed control [32,33].

The ley phase of the rotation was also shown to reduce the propagules of many soil and crop residue-borne diseases, as well as pests that affect annual crops (e.g., cereals and field vegetables) in the rotation $[6,25,26]$. For example, there is evidence that the severity of foliar diseases (e.g., Septoria, Fusarium) in wheat grown after grass clover leys is significantly lower when compared with wheat (Triticum aestivum L.) crops grown after wheat, maize (Zea mays L.) and/or potato (Solanum tuberosum L.) [24,33]. An interaction between the position of wheat crops in the rotation and fertilization regimes (use of organic versus mineral NPK fertilizer) was also recently reported for Septoria severity in the UK [33]. Septoria severity in mineral NPK-fertilized wheat crops was significantly (more than three times) higher when wheat was grown after wheat, compared with wheat grown after a grass-clover ley, whereas the difference in Septoria severity between pre-crops was not significant when crops were fertilized with manure, at the same total $\mathrm{N}$-input level (Figure 2) [33]. However, for some diseases and pests the ley phase can also result in a build-up of inoculum. For example, long grass-clover leys can increase wireworm populations in soils and cause significant yield losses in potato crops that are planted immediately after a ley phase $[20,34]$. In this context, it is interesting to note, that in traditional, organic arable rotations in the UK wheat is grown immediately after leys, and then followed with a potato crop, primarily to reduce Septoria severity in wheat, and wireworm damage in potato (personal communication, Fred Halder, Murtle, Murtle Farm, Camphill Trust Aberdeen, UK).

The inclusion of legume crops in the rotation is prescribed by organic farming standards, and is an important component of the fertility management regime in organic farming systems (see Section 2.2.1 below). In between leys, organic farming regulations prescribe that farmers alternate crops from different plant families, and with contrasting life-cycles, canope structures, rooting patterns and periods of growth, to minimize the accumulation of crop species-specific weeds, disease and pest populations [6,25-28]. Organic rotations are therefore thought to be, overall, more diverse than conventional crop rotations [31], but there is concern that organic ley/arable rotations are not diverse enough to deliver the desired agronomic gains (e.g., reduced weed pressure; optimum nutrient-use efficiency) [35,36]. Therefore, the identification of agronomically useful and economically viable break crops for organic ley/arable rotations remains a major challenge [36].

There have been few studies into the effect of rotation design on nutritional quality and safety parameters in crops. However, one clear example of rotational effects is the use of monoculture or less diverse arable crop rotations in conventional cereal production (e.g., planting wheat after wheat or maize pre-crops, which is common in conventional but not organic rotations) which has been shown to increase Fusarium disease severity, and Fusarium mycotoxin load in cereal grains [37-40]. 


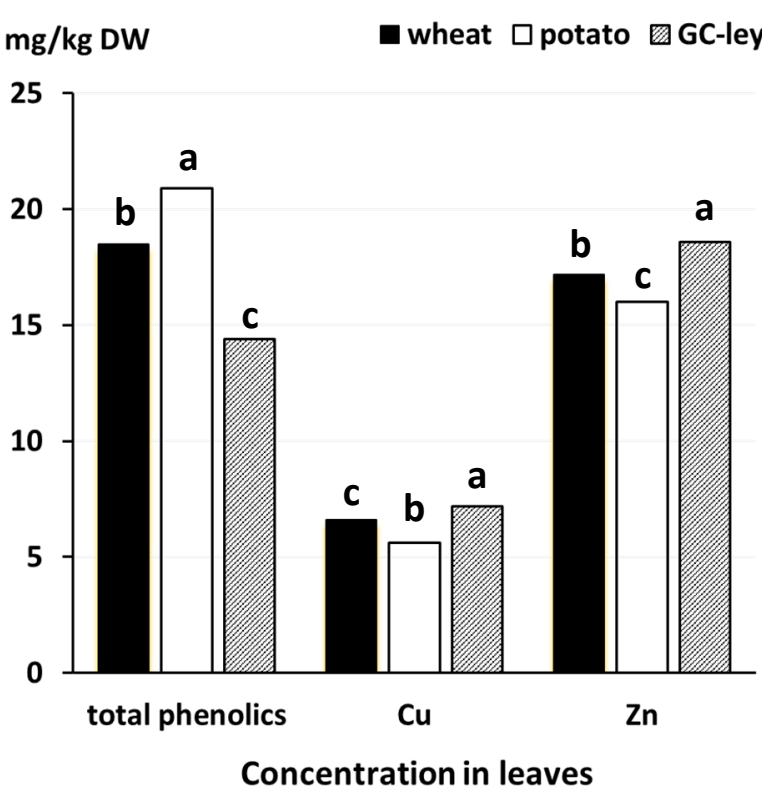

(a)

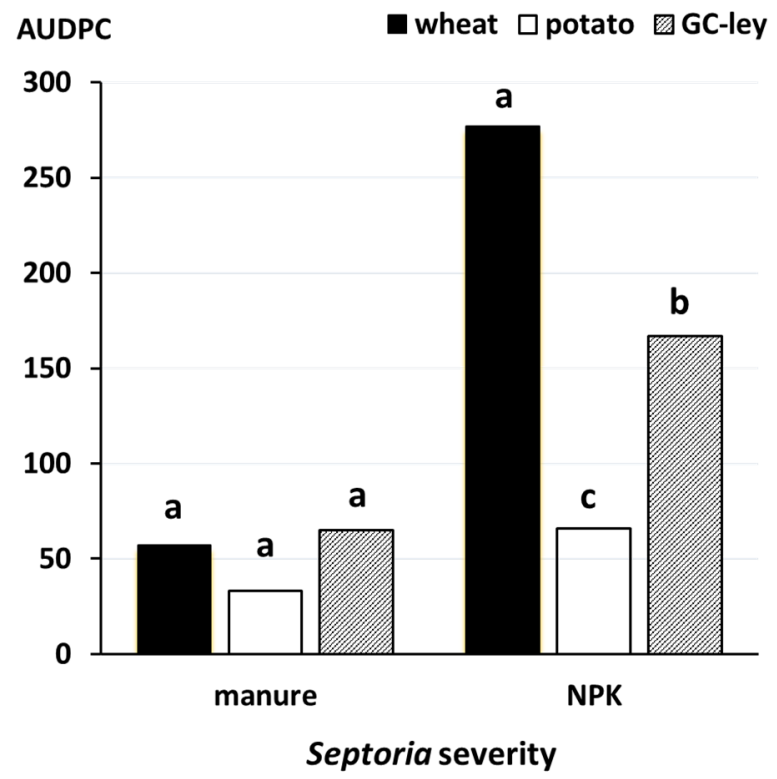

(b)

Figure 2. Effect of (a) preceding crops (wheat, potato, grass-clover [GC] leys) on total phenolic $(p=0.001), \mathrm{Cu}(p=0.002)$ and $\mathrm{Zn}(p=0.013)$ concentrations in wheat leaves and $(\mathbf{b})$ fertilization regime (manure versus mineral NPK fertilizer applied at the same total $\mathrm{N}$-input rate of $170 \mathrm{~kg} \mathrm{~N}$ hectare) and preceding crops on Septoria severity ( $p<0.001$ for interaction) data from [33]. Means for the same composition parameter or fertilizer type labelled with the same letter are not significantly different (Tukey's honest significant difference test, $p<0.05$ ). AUDPC, area under the disease progress curve days $\mathrm{x} \%$ severity.

Moreover, the crops grown before wheat in the rotation were shown to affect (i) leaf phenolic and mineral micronutrient concentrations, and (ii) foliar disease severity in the long-term, factorial Nafferton Farming Systems Comparison (NFSC) Trials [33]. Specifically, this study reported that potato as the pre-crop resulted in significantly higher leaf phenolics, but lower $\mathrm{Cu}$ and $\mathrm{Zn}$ concentrations than wheat and grass clover leys in both manure and mineral NPK-fertilized crops (Figure 2) [33]. More recently, faba bean (Vicia faba L.) cover crops were reported to result in the highest mineral, protein and prebiotic carbohydrate concentrations in subsequent kale (Brassica oleracea L.) crops, when compared with Windham winter pea (Pisum sativum L), hairy vetch (Vicia villosa Roth.), Lynx winter pea, crimson clover (Trifolium incarnatum L.) and ryegrass (Lolium perenne L.) [41].

\subsection{Fertilization Regimes}

In intensive, conventional farming, the use of $\mathrm{N}, \mathrm{P}$, and $\mathrm{KCl}$ fertilizers has increased rapidly over the last 40 years. Whereas nutrient-use efficiency (the amount of mineral NPK needed to produce a $\mathrm{kg}$ of crops) has decreased, the dependence of conventional farming on NPK inputs to maintain current productivity levels has increased [42]. There is now increasing concern about the rapidly rising cost, environmental impact and future availability of mineral NPK fertilizers, since their production requires high amounts of fossil fuels $($ mineral $\mathrm{N})$, and because they are mined minerals and therefore non-renewable resources (mineral $\mathrm{K}$ and $\mathrm{P}$ ) [42-46]. For example, the manufacture and use of mineral $\mathrm{N}$-fertilizer has been estimated to generate $25 \%$ of all greenhouse gas (GHG) emissions from agriculture $(=2.5 \%$ of all GHG-emissions) [46], and according to some independent estimates, the currently known deposits of phosphorus will deplete within the next 60-150 years [43-45].

In contrast, traditionally organic and biodynamic farming systems aim to create closed, on-farm nutrient cycles with a minimum import of nutrients from outside the farm $[4,6,25,26,47]$. In mixed organic farming systems, this is primarily based on (i) livestock depositing manure onto leys during grazing, (ii) the strategic application of farm-yard manure (produced while livestock are housed in barns or corrals) to annual crops (e.g., 
cereals, potato, field vegetables) in the rotation, and (iii) including legume ley or grain crops in the rotation. Since the losses of $\mathrm{N}$ from manure and/or soil are larger than those of $\mathrm{P}$ and $\mathrm{K}$, the use of $\mathrm{N}$-fixing legume crops is also designed to compensate for N-losses, and provide a balanced supply of N:P:K $[6,25,26,36]$. Although the mixed farm is still considered the ideal model for organic farming, economic pressures have resulted in organic farms becoming increasingly specialized [47]. As a result, many specialized arable and horticultural crop producers do not have livestock, and import larger amounts of nutrients in the form of organic materials (e.g., manure, waste-based compost or digestate from biogas-units), permitted mineral P (e.g., finely ground raw phosphate) and K (e.g., $\mathrm{KSO}_{4}$ ), and often also mineral micro-nutrient fertilizer products [6,25,26,30,47]. Stockless organic systems are (i) more dependent on imports of organic (manure, compost) and/or permitted mineral $\mathrm{P}, \mathrm{K}$ and micronutrient fertilizers and (ii) more reliant on mechanical weed control and/or flame weeding, and therefore they are thought to be less sustainable when compared with mixed organic farms $[6,25,27,30,47]$.

It is important to note that the inclusion of energy crops in organic rotations, and the use of digestate from on-farm biogas units as fertilizer, has provided an alternative nutrient recycling option, especially for stockless organic producers [30,48-50]. Moreover, the use of biogas units for manure processing on mixed organic farms is thought to minimize $\mathrm{N}$-losses, since both nitrification and denitrification are inhibited during the anaerobic digestion process [48-50].

The beneficial effects of organic fertilization regimes on nutritional quality and safety parameters have been associated with (i) regular organic matter inputs on soil biological activity, (ii) a more balanced mineralization-driven nutrient (and especially $N$ ) supply pattern from organic fertilizers, and (iii) the non-use of mineral $\mathrm{N}$ and superphosphate (see Section 2.2.1 to Section 2.2.3 below). In contrast, there is limited information on the effect of different types of organic fertilizer (e.g., farm-yard manure, manure slurry, manurecompost manure, green-waste compost, household-waste compost, alfalfa pellets) on the nutritional composition of crops.

\subsubsection{Replacing Mineral N-Fertilizer with Organic Fertilizer Inputs}

There is now a range of studies that report that using organic fertilizers such as manure, instead of mineral NPK-based fertilization regimes, results in higher leaf and/or grain phenolic concentrations, but reduced levels of lodging in cereals and foliar disease severity in both cereals and other crops [13,33,51-54]. For example, in the NFSC trials, phenolic concentrations were significantly lower, whereas powdery mildew and/or rust severity were significantly higher in mineral NPK, compared with manure-fertilized wheat crops $[13,33]$. In addition, in the years when the performance of wheat grown after contrasting preceding crops could be compared, wheat grown after grass-clover leys and mineral NPK as fertilizer had the highest mildew and lowest phenolics levels (Figure 3). It is well known that phenolic compounds, which have antimicrobial activity, are a component of both constitutive and salicylic acid (SA)-inducible systemic resistance mechanisms in plants [51]. Moreover, it has been demonstrated that increasing N-availability to plants, significantly reduces the concentrations of phenolic compounds and resistance against biotropic diseases in a dose-dependent manner [52-54].

These results are of nutritional relevance, since phenolics are one of the main phytochemical groups with antioxidant activity in crops, and increased dietary intake of different types of phenolics has been linked to health benefits in humans, including a reduced risk of cardiovascular disease, type-2 diabetes and cancer [55]. 


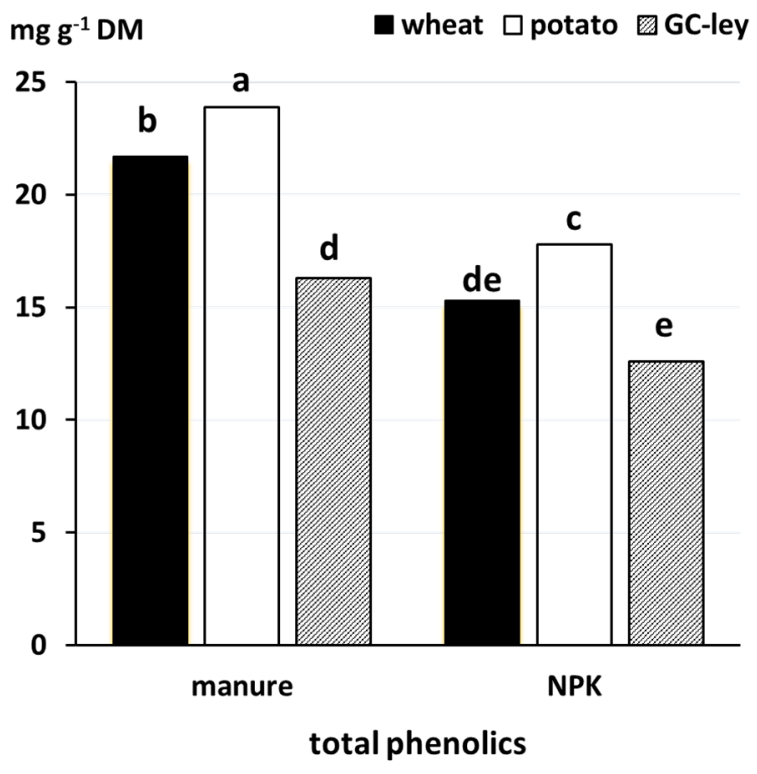

(a)

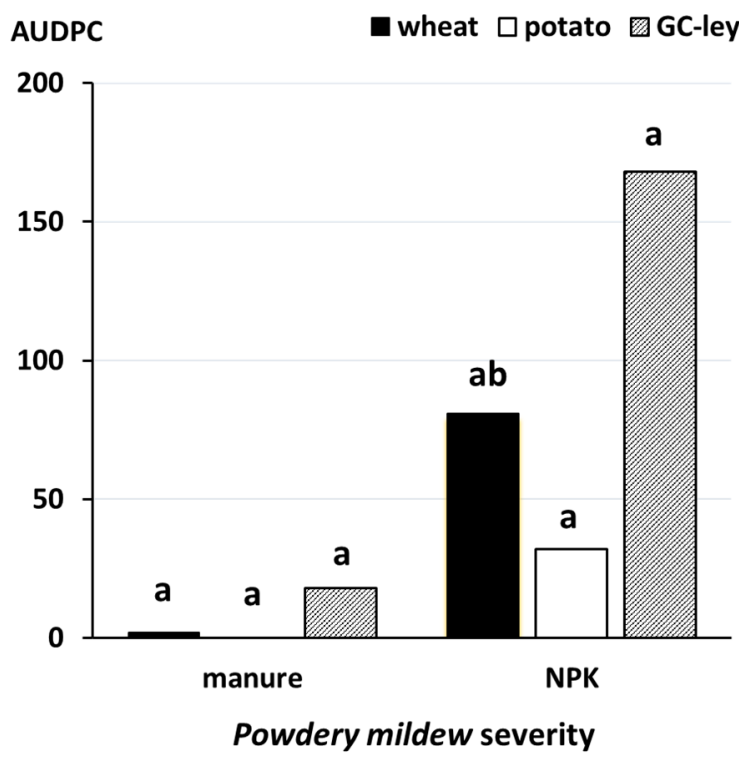

(b)

Figure 3. Effect of fertilization regime (F; manure versus mineral NPK fertilizer applied at the same total N-input rate of $170 \mathrm{~kg} \mathrm{~N}$ hectare) and preceding crop (PC) on (a) total phenolic concentrations ( $p=0.089$ for $\mathrm{F} \times \mathrm{PC}$ interaction), and (b) powdery mildew severity ( $p<0.001$ for FxPC interaction) in wheat leaves data from [33]. Means labelled with the same letter are not significantly different (Tukey's honest significant difference test, $p<0.05$ ). AUDPC, area under the disease progress curve days x \% severity; DM, dry matter.

Results from the NFSC trials and other studies [56-58] have suggested that replacing mineral NPK fertilizer inputs with manure at the same N-input level can also result in increased concentrations of other phytochemicals with antioxidant activity in crops, including vitamin C and folate in potato, cabbage (Brassica oleracea L.) and lettuce (Lactuca sativa L.), glucosinolates in cabbage, and total carotenoids in cabbage (Table 1).

In contrast, concentrations of toxic glycoalkaloids in potato tubers were significantly lower when manure, instead of mineral NPK, was used as fertilizer in the NFSC trials (Table 1). However, the effects of mineral NPK versus organic fertilizer use on nonresistance related phytochemicals are less consistent than those observed for phenolics. For example, in the NFSC trials, the use of manure instead of mineral NPK resulted in slightly $(\sim 5-10 \%)$, but significantly, lower concentrations of tocopherol and tocotrienol in wheat grain [58].

Differences in the N-supply pattern from organic and mineral N-fertilizer are also thought to, at least partially, explain the results of (i) the NFSC trials, and (ii) recent systematic reviews/meta-analyses and retail surveys that reported higher levels of antioxidant activity and concentrations of phytochemicals with antioxidant activity in organic crops, compared with conventional crops [56-60]. However, previous studies and the NFSC trial results demonstrated that rotation design, variety choice and crop protection regimes may have also contributed to differences in phytochemical concentrations and antioxidant activity levels between organic and conventional crops [7,12,13,19,50,51,53,57-60] (Table 1; Figure 3; Section 2.3).

Mineral N-fertilizer use is thought to be the main reason for the significantly higher protein, nitrate and nitrite concentrations found in conventional crops, compared with organic crops in meta-analyses and the NFSC trials, but there is uncertainty about the potential nutritional and health impacts [57] (see also Section 2.3 below). 
Table 1. Effect of the crop protection (organic versus conventional) and fertilization regime (mineral NPK vs cattle manure) on nutritionally relevant phytochemicals in potato, cabbage and lettuce grown in the NFSC trial data from [58]; values shown are main effect means; yield results are from 9, 6, 4 and 4 growing seasons for potato, cabbage, lettuce and onion (Allium cepa L.), respectively; phytochemical and/or nitrate results are from 3 or 4 growing seasons for potato, cabbage, lettuce and onion.

\begin{tabular}{|c|c|c|c|c|c|c|c|c|}
\hline \multirow[b]{3}{*}{ Crop } & \multirow[b]{3}{*}{ Parameter Assessed } & \multirow{2}{*}{\multicolumn{2}{|c|}{$\begin{array}{c}\text { Crop Protection } \\
\text { (CP) }\end{array}$}} & & & \multicolumn{3}{|c|}{ ANOVA Results ( $p$-Values) } \\
\hline & & & & \multicolumn{2}{|c|}{ Fertilization (F) } & \multicolumn{2}{|c|}{ Man Effects } & \multirow{2}{*}{$\begin{array}{c}\text { Inter-Action } \\
\mathrm{CP} \times \mathbf{F}\end{array}$} \\
\hline & & CON & ORG & $\begin{array}{l}\text { Mineral } \\
\text { NPK }\end{array}$ & $\begin{array}{l}\text { Cattle } \\
\text { Manure }\end{array}$ & $\mathbf{C P}$ & $\mathbf{F}$ & \\
\hline \multirow[t]{6}{*}{ Potato } & Marketable tuber yield (t/ha) & 9.2 & 7.7 & 9.3 & 7.6 & $<0.001$ & $<0.001$ & 0.003 \\
\hline & total phenolics $(\mu \mathrm{g} / \mathrm{g} \mathrm{FW})$ & 285 & 293 & 277 & 301 & NS & 0.016 & NS \\
\hline & vitamin $C(\mu \mathrm{g} / \mathrm{g} F W)$ & 95 & 97 & 91 & 101 & NS & $<0.001$ & NS \\
\hline & total carotenoids $(\mu \mathrm{g} / \mathrm{g}$ FW) & 0.7 & 0.8 & 0.7 & 0.7 & 0.060 & NS & 0.018 \\
\hline & folate $(\mu \mathrm{g} / \mathrm{g} F W)$ & 0.17 & 0.18 & 0.17 & 0.18 & NS & $<0.001$ & 0.006 \\
\hline & glycoalkaloids (mg/kg FW) & 42 & 40 & 45 & 37 & NS & $<0.001$ & NS \\
\hline \multirow[t]{7}{*}{ Cabbage } & Yield (t/ha FW) & 54 & 61 & 71 & 45 & $<0.001$ & $<0.001$ & 0.007 \\
\hline & total phenolics ${ }^{1}(\mu \mathrm{g} / \mathrm{g} \mathrm{FW})$ & 11.0 & 9.4 & 8.8 & 11.6 & 0.093 & 0.001 & NS \\
\hline & vitamin $C(\mu \mathrm{g} / \mathrm{g} F W)$ & 224 & 223 & 211 & 236 & NS & 0.006 & NS \\
\hline & total carotenoids $(\mu \mathrm{g} / \mathrm{g}$ FW) & 3.5 & 3.2 & 3.0 & 3.7 & NS & 0.008 & 0.051 \\
\hline & folate $(\mu \mathrm{g} / \mathrm{g} \mathrm{FW})$ & 0.4 & 0.3 & 0.3 & 0.4 & $<0.001$ & 0.022 & NS \\
\hline & total glucosinolates (g/g FW) & 1.37 & 1.23 & 1.13 & 1.48 & 0.037 & $<0.001$ & NS \\
\hline & total volatiles ${ }^{2}$ (mg/g FW) & 33 & 31 & 28 & 35 & NS & $<0.001$ & 0.032 \\
\hline \multirow[t]{5}{*}{ Lettuce } & Yield (t/ha FW) & 38 & 36 & 39 & 34 & NS & $<0.001$ & NS \\
\hline & total phenolics $(\mu \mathrm{g} / \mathrm{g}$ FW) & 104 & 108 & 102 & 112 & NS & 0.036 & NS \\
\hline & vitamin $C(\mu \mathrm{g} / \mathrm{g}$ FW $)$ & 6.8 & 6.7 & 6.8 & 6.7 & NS & NS & NS \\
\hline & total carotenoids $(\mu \mathrm{g} / \mathrm{g}$ FW) & 4.4 & 5.0 & 4.6 & 4.8 & 0.085 & NS & NS \\
\hline & folate $(\mu \mathrm{g} / \mathrm{g} F W)$ & 0.3 & 0.3 & 0.3 & 0.3 & 0.064 & 0.042 & NS \\
\hline \multirow[t]{5}{*}{ Onion } & Marketable yield (t/ha FW) & 22 & 20 & 21 & 21 & NS & NS & NS \\
\hline & total phenolics ${ }^{3}(\mu \mathrm{g} / \mathrm{g}$ FW) & 725 & 721 & 740 & 706 & NS & NS & NS \\
\hline & vitamin $C(\mu g / g$ FW $)$ & 100 & 93 & 86 & 107 & NS & NS & NS \\
\hline & total carotenoids ( $\mu \mathrm{g} / \mathrm{g}$ FW) & 0.6 & 0.7 & 0.7 & 0.6 & NS & NS & 0.083 \\
\hline & folate $(\mu g / g$ FW) & 0.4 & 0.4 & 0.4 & 0.4 & NS & NS & NS \\
\hline
\end{tabular}

Significantly higher means are shown in bold. NS, not significant; Main effect means of crop protection or fertilization treatments that resulted in significantly higher values are shown in bold; $\mathrm{CP}$, crop protection; $\mathrm{CON}$, conventional crop protection based on synthetic chemical pesticides (herbicides, fungicides and insecticides); ORG, organic crop protection based on mechanical weed control and hand weeding and the use of $\mathrm{Cu}$-fungicides in potato only; ${ }^{1}$ total hydroxycinnamic acid derivatives; ${ }^{2}$ sum of hexanal, 3 -butenenitrile, (E)-2-Hexenal and 2-propenyl isothiocyanate; ${ }^{3}$ flavonoids.

\subsubsection{Replacing Superphosphate with Organic Fertilizer Inputs}

The use of water-soluble P-fertilizers (superphosphate, triple superphosphate) is known to suppress mycorrhizal development in crop plants [61]. Mycorrhizal fungal associations have been shown to provide benefits to crop plants, including (i) improved uptake efficiency of $\mathrm{P}$ and micronutrients such as $\mathrm{Zn}, \mathrm{Cu}$ and $\mathrm{Se}$, (ii) increased resistance against soil-borne diseases, and (iii) greater tolerance against abiotic stress, including drought [61,62].

Organic crop management has been reported to result in higher densities and diversity of mycorrhizal fungal inocula in soil, and increased colonization and mycorrhizal development on plant roots [61-63]. The non-use of water-soluble P-fertilizers in organic farming systems may, therefore have (i) contributed to the positive impacts of organic fertilization regimes on crop health (see e.g., Figures 2 and 3) and/or (ii) explained the higher concentrations of nutritionally desirable mineral micronutrients detected in organic crops in some comparative studies [57,59].

It is well known that the application of water-soluble mineral-P fertilizer results in an increase in the concentration of toxic metal cadmium (Cd) in crop plants [64-66]. 
All phosphorus fertilizers contain $\mathrm{Cd}$ as a contaminant and levels may vary from trace amounts, to as much as $300 \mathrm{mg} \mathrm{Cd} \mathrm{kg}^{-1}$ of dry product [64]. Fertilization can influence $\mathrm{Cd}$ accumulation in crops by direct $\mathrm{Cd}$ addition with P-fertilizers, and by indirect effects on rhizosphere chemistry, soil microbial activity, soil $\mathrm{pH}$ and $\mathrm{Zn}$ concentration, and by affecting plant growth [64-66].

Systematic reviews and meta-analyses reported that organic cereals have significantly lower $\mathrm{Cd}$ concentrations, but there is insufficient published information for other crops [57]. Results from the NFSC trials demonstrated that the use of mineral NPK fertilizer results in significantly higher $\mathrm{Cd}$ concentrations, when compared with manure at the same total $\mathrm{N}$-input level, in a range of crops, including wheat, potato, cabbage, onion and lettuce (Figure 4). However, it is important to point out that, in the meta-analyses of published data, significant differences in $\mathrm{Cd}$ concentrations between organic and conventional cereals were only detected in experimental studies, whereas analyses of farm and retail survey data showed no significant differences for $\mathrm{Cd}$ [57]. In most experimental studies (including the NFSC trials), no permitted mineral-P fertilizer was applied in the organic management plots $[57,58,65]$, whereas finely ground rock-phosphate (which also contains $\mathrm{Cd}$ as a contaminant) is used on many commercial organic farms, and especially by stockless arable and specialist horticultural producers $[6,25,26]$. This may explain the contrasting results obtained in experimental studies and farm/retail surveys, and indicates that there is potential to reduce $\mathrm{Cd}$ exposure by reducing mineral P-inputs in both organic and conventional farming.

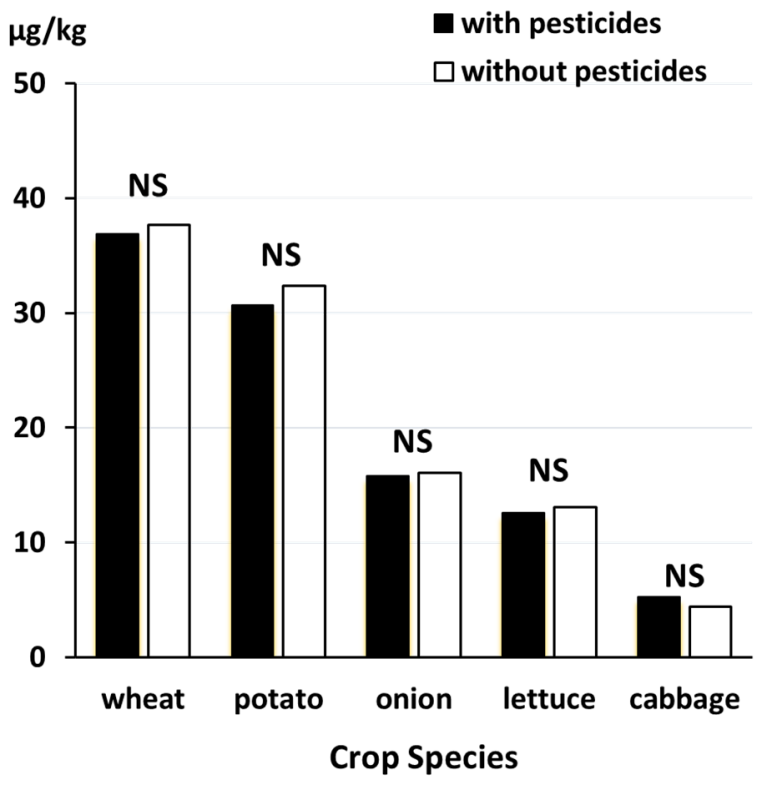

(a)

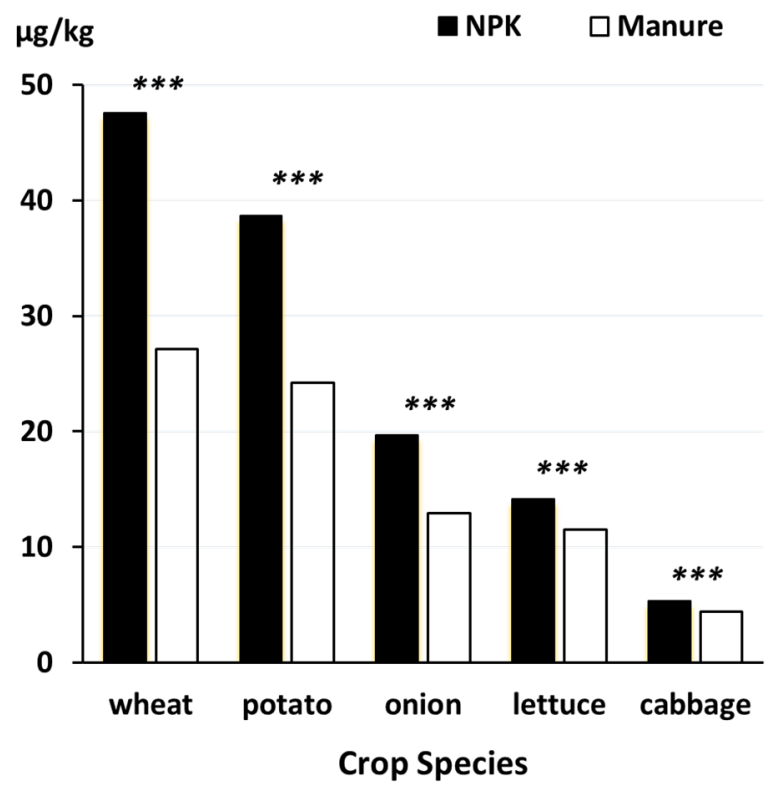

(b)

Figure 4. Effect of contrasting (a) crop protection (with and without the use of synthetic chemical pesticides) and (b) fertilization regimes (mineral NPK versus manure applied at the same total N-input rate of $170 \mathrm{~kg} \mathrm{~N}$ hectare) used in organic and conventional farming on cadmium concentrations in wheat grain, potato tubers, onions, cabbage heads and lettuce leaves Data from $[58,65]$. Bars represent the main effect means of data from four (potato, onion, lettuce, cabbage) or five (wheat) growing seasons. ${ }^{* *}$, significant difference $(p<0.001)$; NS, not significant.

In this context, it should be noted that the wheat, potato and vegetable cultivars used in the NFSC trials were varieties from conventional farming-focused breeding programs, which were selected for performance in conventional mineral NPK-fertilized production systems. As described in Section 2.4 (see below), varieties selected in conventional NPKfertilized agronomic backgrounds may be at a reduced capacity to develop functional mycorrhizas. This may also affect micronutrient and toxic metal uptake [58]. 


\subsubsection{Rhizobium and Mycorrhizal Fungal Inocula}

Organic farming standards permit the use of symbiotic microbial inocula that improve $\mathrm{N}$-fixation in soil (e.g., Rhizobium or free-living $\mathrm{N}$-fixing bacteria) and nutrient uptake by plants (e.g., VA-mycorrhizal fungi) [4]. However, there is controversy about whether such inocula are necessary and deliver substantial benefits on mixed organic farms with diverse rotations that have been under organic management for many years $[6,25,26]$.

Rhizobium inocula are used in both conventional and organic farming, especially for grain legumes [67-71] and were shown to increase $\mathrm{N}$-fixation and soil- $\mathrm{N}$ and $\mathrm{N} /$ crude protein in grain legume and cereal crops grown after inoculated grass-clover leys [69]. Rhizobium species are legume species-specific and when new legume crops (e.g., soya) are introduced into rotations, treatments of seed with Rhizobium inocula is recommended [71]. The use of Rhizobium inocula was also reported to increase mycorrhizal development from 'natural' mycorrhizal fungal inocula present in soil [70]. The combined use of (i) Rhizobium inocula for clover during the establishment of a two-year clover ley and (ii) application of domestic waste compost with a high C:N ratio was proposed as a strategy to increase $\mathrm{N}$-fixation and avoid N-losses [69]. N-losses can be substantial when grass clover leys are incorporated into soil and the combined use of Rhizobium inocula and high C:N ratio compost was demonstrated to substantially increase both yield and protein concentration in organic wheat crops established after leys [69]. There is, to our knowledge, limited published information on the effects of Rhizobium inocula on other nutritionally relevant quality parameters.

Mycorrhizal inocula are not widely used in both conventional and organic food crop production, although a lot of research has been done on their development [71-76]. This is thought to be mainly because arbuscular mycorrhizal fungal (AMF) inoculum products are relatively expensive, and produce inconsistent and sometimes negative effects on crop yields [71-76]. Moreover, it remains unclear whether, and to what extent, AMF inocula increase $\mathrm{P}$ and mineral micronutrient uptake and concentrations in crop plants [76].

The effect of AMF inocula on vitamin and antioxidant levels in vegetables was compared in manure and mineral NPK-fertilized crops in the Rodale Institute's long-term farming system trial [72]. AMF-inoculation significantly reduced vitamin $C$ and antioxidant levels in carrots (Dacus sativus Hoff.), but had no consistent effect in bell peppers (Capsicum annuum L.) or tomato (Solanum lycopersicum L.) crops [72]. Interestingly, the reduction in vitamin $C$ from AMF-inocula was significantly greater in the mineral NPK-fertilized conventional system (87\%) than in the manure-fertilized organic system (28\%) [72].

\subsection{Crop Protection}

Crop protection in organic farming systems is based on the integrated use of preventative management strategies and intervention methods for weed, disease and pest control $[6,25,26]$. Several important components of organic crop-health management regimes also affect the nutritional quality and safety of crops: these are described in separate sections/subsections below. Specifically, organic crop protection is based on the following practices:

- Use of diverse crop rotation (see Section 2.1 above);

- Non-use of water-soluble mineral N and P-fertilizers (see Section 2.2 above);

- Use of organic fertilizers and soil amendments to increase soil suppressiveness (see Section 2.3.1 below);

- Use of environmental enrichment measures to increase populations of natural enemies of invertebrate pests on farms (see Section 2.3.2);

- Use of elicitors for crop resistance where necessary (see Section 2.3 .3 below);

- Use of biological control products for pest and disease control where necessary (see Section 2.3.4 below);

- Use of barrier, mating disruption, and mass-trapping methods for pest control where necessary (see Section 2.3.5 below); 
- Use of thermal weed control or soil disinfection; these practices are increasingly restricted and should only be used as a last resort (see Section 2.3.6 below);

- Use of pesticide products that are permitted in organic farming; these products should only be used as a last resort (see Section 2.3.6 below);

- Non-use of all synthetic chemical pesticides (see Section 2.3.7 below).

In contrast, crop protection in intensive conventional farming systems relies heavily on the use of synthetic chemical pesticides, which are prohibited in organic farming [4]. It is important to note that many management practices (e.g., monoculture and short rotations, zero and minimum tillage) used in conventional farming are dependent on regular pesticide applications $[5,29,31,35,42,57]$.

Differences in the level of pesticide use between organic and conventional farming systems are thought to have the largest potential direct and indirect effects on food quality and safety, and human health [57]. The current knowledge about the effects of organic versus conventional crop protection protocols on (i) pesticide residues, and (ii) other nutritionally relevant compounds in food crops are therefore also described separately, in Section 2.3.7 below.

\subsubsection{Soil/Substrate Suppressiveness against Pests and Diseases}

Regular inputs of organic matter have been shown to increase the organic matter content, biological activity, microbial and invertebrate biodiversity, structural stability and erosion resistance of agricultural soils [77-80].

Organic matter inputs, in particular composts produced in controlled aerobic composting processes, were also shown to increase (i) the suppressiveness of soils against soil-borne bacterial and fungal diseases and nematodes [81-90], and (ii) the populations of beneficial invertebrates (e.g., ground beetles) in soils [80,87,88]. Close associations between the increase in soil biological activity and disease suppressiveness associated with organic matter/compost inputs have also frequently been observed $[83,84,86]$. Suppressive composts can be made from a range of organic feedstocks and are widely used in commercial organic horticultural production systems [86-88].

An extensive review of published studies by Bonanomi and co-workers [87] examined 252 scientific papers and reported positive correlations between disease suppressiveness of soils after compost/organic matter inputs and (i) soil biological activity, and (ii) concentrations of specific groups of antagonistic soil microorganisms (e.g., Trichoderma species, fluorescent pseudomonads) in soil. The finding that soil chemical or steam disinfection was shown to significantly reduce or eradicate disease suppressiveness also suggests that components of soil biota are a major driver for "disease suppressiveness" [87].

However, some organic waste materials used as feed material for compost were also shown to reduce disease severity via (i) inducing crop resistance mechanisms (e.g., the chitin soil amendments made from shellfish processing waste) $[83,84]$ or (ii) releasing phytochemicals (e.g., tannins, phenolic compounds and isothiocyanates) that directly inhibit pathogen development in the soil (e.g., Brassica crop residues/waste or bark from certain tree species) $[83,84,88-90]$. It is interesting to note that the use of Brassica cover crops/green manures, which have a "biofumigation" effect when incorporated into the soil, are now recommended as an alternative method to chemical soil disinfection for the control of parasitic nematodes in both conventional and organic farming [90].

There is limited information on the effect of organic soil amendments on the nutritional composition of crop plants. However, the use of soil amendments that induce crop resistance (e.g., chitosan, chitin) has been linked to higher phenolic concentrations and antioxidant activity in vegetables, herbs and fruit and/or increased antioxidative and antimutagenic activity in organic green vegetables (see Section 2.3.3 below) [91-93].

\subsubsection{Environmental Enrichment Practices}

Environmental enrichment/diversification practices include the use of (i) companion plants and intercrops to distract invertebrate pests and thereby reduce pest damage, and 
(ii) managed field margins and/or within-field beetle banks to maintain high population densities of natural enemies of crop pests and/or pollinators [80,94-100] (https:/ / youtu. be/XVPP6W0m1GA, accessed 30 November 2021). The use of diversification strategies is thought to be more prevalent in organic farming systems. Moreover, natural enemy and pollinator density_-but not necessarily diversity - was reported to be greater on organic farms $[96,97,101,102]$ However, in most studies it remained unclear to what extent the effects on pest and pollinator populations were due to the non-use of insecticides or environmental enrichment practices used on organic farms.

The studies of natural enemy populations by Eyre and co-workers [80,95-97] suggested that a wide range of parameters, including crop type, and contrasting fertilization and crop protection methods used in organic and conventional farming, but also field margin vegetation and landscape features, affect natural enemy populations. For example, in the NFSC trial plots, ground beetle abundance was greater in many crops when manure instead of mineral NPK was used as fertilizer. However, abundance was reduced by insecticide applications [80]. In contrast, in wheat crops, the abundance of spiders was greater in mineral NPK, compared with manure-fertilized plots [80].

There is, to our knowledge, no information on the effects of environmental enrichment on the nutritional composition of crop plants, apart from contributing to crops being grown with lower or no pesticide inputs. However, the benefits of organic farming practices on pollinator populations are thought to improve the sustainability of crop production and future food security $[96,97,101,102]$.

\subsubsection{Elicitors of Crop Resistance}

Elicitors permitted for use in organic farming are produced from plant extracts or organic waste materials, and are primarily used for the control of seed-borne [103,104], soil-borne $[83,84,91]$ and foliar diseases [51,91-93,105-107]. The main compounds currently available and used by commercial organic farmers are:

- Chitin (a long-chain polymer of $\mathrm{N}$-acetylglucosamine, which is a primary component of fungal cell walls and the exoskeleton of insects and crustaceans) is mainly produced from the shells of shrimps and other crustaceans;

- Chitosan (a linear polysaccharide composed of randomly distributed $\beta-(1 \rightarrow 4)$-linked D-glucosamine and $N$-acetyl-D-glucosamine) is produced by treating the chitin shells of shrimp and other crustaceans with an alkaline substance, such as sodium hydroxide;

- Giant knotweed (Reynoutria sachalinensis Schmidt ex Maxim.) extracts (tradename: Milsana ${ }^{\circledR}$ ).

Soil and foliar chitin/chitosan, and foliar Giant knotweed extract treatments were shown to induce salicylic acid-dependent defense responses in plants, which includes the increased expression of phenolics and other phytochemicals with antioxidant activity in crop plants $[51,91-93,107]$. For example, the large difference in antioxidant activity between organic and conventional spinach (Spinacia oleracea L.) and onion observed in Japan [91] was linked to (i) $500 \mathrm{~kg}$ chitosan/ha being incorporated into the soil before planting, and (ii) crops being sprayed regularly with a $0.01 \%$ chitosan solution during the growing season (Figure 5).

However, it is important to note that differences in fertilization regimes (e.g., the use of manure instead of mineral NPK fertilizer for organic vegetables) are also likely to have contributed to the higher antioxidant activity in organic crops observed in this study (see also Section 2.2 above). 


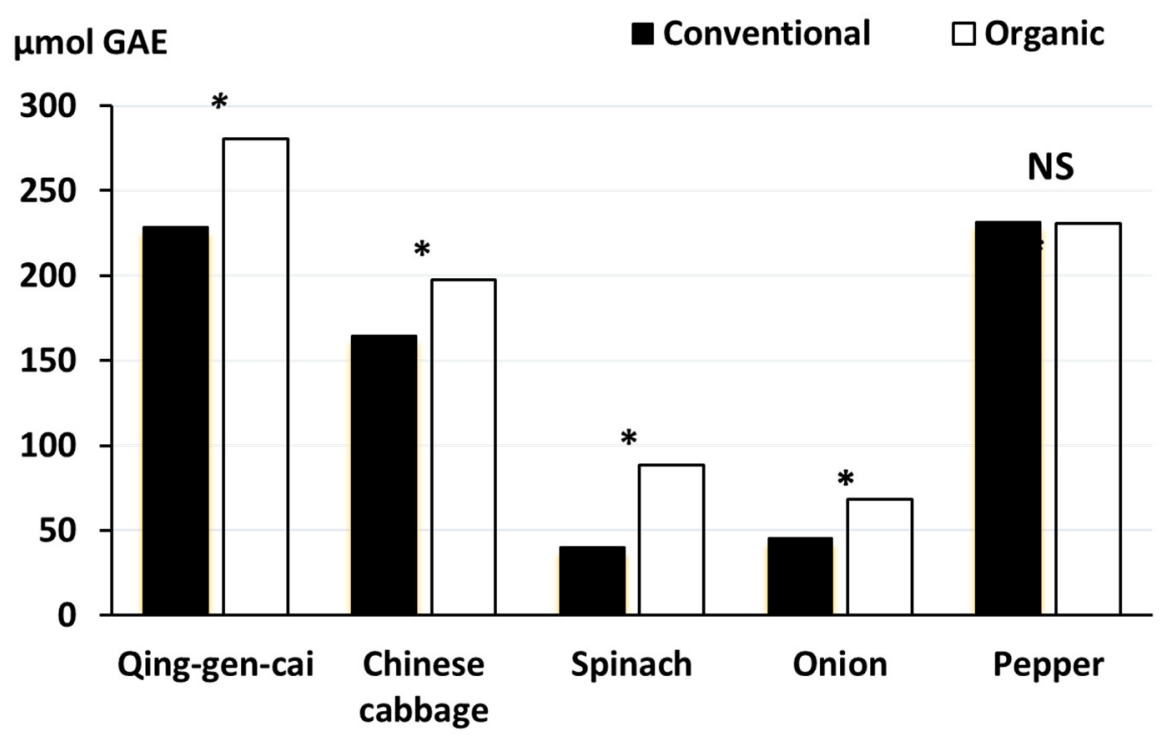

\section{Vegetable Species}

Figure 5. Effect of crop management (organic vs conventional) on antioxidant activity/capacity in vegetables. GAE, gallic acid equivalents data from [91]. The organic (but not the conventional) crop management included the incorporation of $500 \mathrm{~kg}$ chitosan/ha before planting, and crops being sprayed regularly with a $0.01 \%$ chitosan solution during the growing season. ${ }^{*}$, significant difference $(p<0.05)$; NS, not significant.

\subsubsection{Biological Control Products}

Biological pest and disease control products are permitted under EU organic farming regulations [4] and pest control products based on Bacillus thuringiensis (Bt), or natural enemies of invertebrate pests, are widely used [6,25,26,108].

Biological control products based on predators and parasitoids are now available for a wide range of invertebrate pests/herbivores, and are extensively used in both organic and conventional production systems and especially protected horticultural crops [108]. It would go beyond the scope of this review to describe the different products and their mode of action, but detailed information on the products available to farmers can be found on the websites of the main producers/suppliers of biological control products (e.g., Koppert B.V., Berkel, The Netherlands; www.koppert.com/products-solutions, accessed on 29 November 2021; Biobest Group NV, Westerlo, Belgium, www.biobestgroup.com/en/ biobest/products, accessed on 29 November 2021).

There has also been extensive research and development efforts to develop biological control products for crop diseases based on bacterial (e.g., Bacillus and Pseudomonas spp.) and fungal antagonists (e.g., Trichoderma spp.) and a range of products are now commercially available and used in organic farming $[109,110]$. However, compared with Bt and natural enemy-based biological pest control products, biological disease control products are thought to be less widely used in organic farming $[83,86]$. This is thought to be mainly because they are relatively expensive and/or were found to provide less effective and/or reliable disease control than other crop protection strategies available to organic farmers (resistant varieties, sulphur fungicides, biofumigation, suppressive composts and/or elicitor-based soil or foliar treatments); see Sections 2.3.1 and 2.3.3 above, and Sections 2.3.5 and 4.4 below [51,81-90,103-107].

Biological control products are not known to produce detectable chemical residues in foods, and there are currently no concerns about potential negative health impacts of the consumption of crops treated with biological crop-protection products [111].

There is, to our knowledge, no information on the effects of biological control products on nutritional composition parameters, apart from contributing to reducing pesticide use and thereby the risk of pesticide residues being present in foods. 


\subsubsection{Barrier, Mating Disruption, and Mass-Trapping Methods for Pest Control}

Barrier-based pest control strategies (e.g., the use of crop covers, netting and insect proof green and screenhouses) are permitted and widely used for pest control in organic horticultural crop production $[4,112,113]$. However, compared with unprotected open field conditions, the use of insect-proof screens was reported to (i) increase relative humidity by $2-21 \%$; (ii) reduce solar radiation by $50-87 \%$; (iii) reduce air velocity by between 15 and $39 \%$, and (iv) affect air temperature and evapotranspiration [114]. These changes in environmental conditions are also known to have significant effects on crop growth, yield, and quality parameters [114]. For example, they may explain the lower folate and glucosinolate concentrations in cabbage crops grown with organic crop protection regimes (which used insect-proof crop covers for pest control only), when compared with cabbage crops produced with conventional, pesticide application-based crop protection regimes (Table 1). It is interesting to note that in the NFSC trials, cabbage was the only vegetable crop in which (i) netting was used in the organic crop protection protocol; (ii) significant main effects of crop protection on nutritionally desirable phytochemicals were detected, and (iii) significantly lower pest damage and higher crop yields were recorded in crops grown with organic regimes, compared with conventional crop protection regimes (Table 1).

Organic farming standards also permit the use of pheromone sprays for mating disruption, the release of sterile males, and mass-trapping based on pheromones and nutrient attractants for pest control [4]. These methods are extensively used by organic farmers, especially in perennial horticultural crops including apples (Malus domestica Borkh.), citrus (Citrus L.) and olives (Olea europaea L.) [115-120], and are thought to have a substantially lower impact on natural enemy populations than (i) synthetic chemical insecticides used in conventional farming, and (ii) plant and microbial fermentation-based insecticides (pyrethrum, spinosad) that are permitted and used for pest control in both organic and conventional production [120].

There is limited information on the effects of barrier, mating disruption, and masstrapping methods on the nutritional quality of crops, although it should be noted that they can have a significant impact on minimizing pesticide use and residues in food [115-120].

\subsubsection{Thermal Crop Protection Methods and Pesticide Products Used in Organic Farming}

The use of thermal soil disinfection and weed control methods are permitted and used in organic farming, although the use of thermal soil disinfection is now restricted by many organic certification bodies $[4,121]$. This is mainly because thermal crop protection substantially increases fossil fuel use and the carbon footprint of food production, and was shown to have negative impacts on soil structure and biological activity [121].

The use of pesticides made from mined minerals (e.g., S-fungicides and insecticides; $\mathrm{Cu}$-fungicides and bactericides) is permitted in both organic and conventional farming systems $[4,6,25,26,122]$, although the use of Cu-products is restricted under EU-farming regulations to $6 \mathrm{~kg} \mathrm{Cu} / \mathrm{ha} /$ annum, and requires farmers to justify and obtain a derogation from their certification body [4].

In the NFSC trials, $\mathrm{Cu}$-fungicides (at a rate equivalent to $6 \mathrm{~kg} \mathrm{Cu} / \mathrm{ha} / \mathrm{annum}$ ) were only used in the organic crop protection regime for late blight control in potato crops [20]. Conventional crop protection regimes for potatoes used synthetic chemical fungicides for late blight control. The finding that potato tubers from $\mathrm{Cu}$-fungicide treated plots (organic crop protection) had significantly higher $\mathrm{Cu}$ concentrations than potatoes from plots treated with synthetic chemical fungicides (Figure 6) suggests that the use of $\mathrm{Cu}$ fungicide can increase $\mathrm{Cu}$-concentration in crops. This view is supported by the finding that $\mathrm{Cu}$-concentrations were not significantly different (lettuce, onion) or higher with conventional crop protection (cabbage) in the other vegetable crops grown in the NFSC trials (Figure 6). 


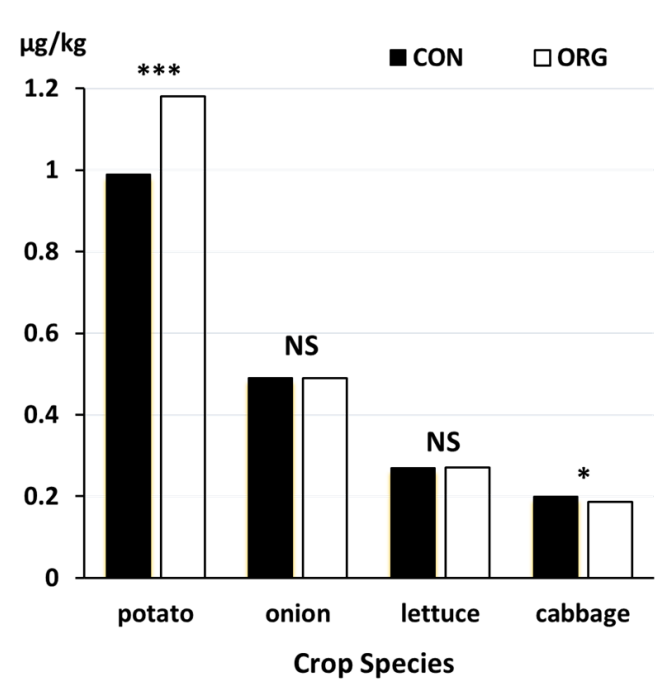

(a)

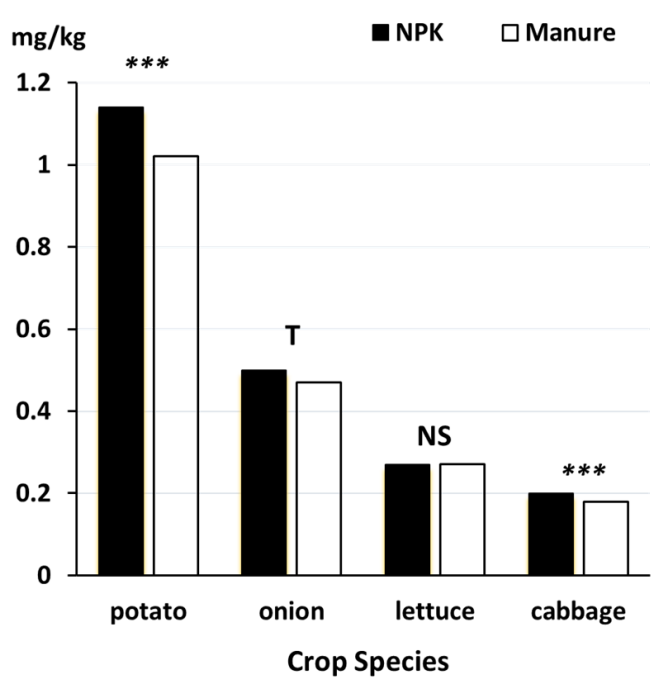

(b)

Figure 6. Effect of contrasting (a) crop protection (CON, conventional crop protection based on synthetic chemical herbicides, fungicides and insecticides; ORG, organic crop protection based on mechanical weed control and hand weeding and the use of $\mathrm{Cu}$-fungicides in potato only) and (b) fertilization regime (mineral NPK versus manure applied at the same total $\mathrm{N}$-input rate of $170 \mathrm{~kg} \mathrm{~N}$ hectare) used in organic and conventional farming on copper concentrations in potato tubers, onions, cabbage heads and lettuce leaves, Data from [58]. Bars represent main effect means of data from four growing seasons. ${ }^{* *}$, significant difference $(p<0.001) ;{ }^{*}$, significant difference $(p<0.05)$; T, trend $(0.01<p<0.05)$; NS, not significant.

It is important to note that $\mathrm{S}$ and $\mathrm{Cu}$ are essential mineral nutrients for both plants and animals/humans, and that there are currently no concerns about potential negative health impacts of the consumption of crops treated with mineral-based crop-protection products $[4,111,122]$. However, there is concern about (i) the potential health implications for farmers handling $\mathrm{Cu}$-fungicides, because concentrated $\mathrm{Cu}$ solutions are highly toxic and can be taken up through the skin, and (ii) negative environmental impacts (e.g., reduced soil biological activity or phytotoxicity) of extensive $\mathrm{Cu}$-fungicide use in orchard crops (e.g., apple, grapevine) [111,122,123].

Organic farming standards permit the use of a small number of insecticide products based on plant extracts (e.g., pyrethrin and azadirachtin, which are made from chrysanthemum [Chrysanthemum indicum L.] flowers and the neen tree [Azadirachta A. Juss.] fruit, respectively) or microbial fermentation extracts (e.g., spinosad, which is made from the insecticidal chemicals spinosyn A and D produced by the actinomycete Saccharopolyspora spinosa) for crop protection [4].

Similar to synthetic chemical insecticides, pyrethrin, azadirachtin and spinosad may also have negative effects on non-target invertebrates including (i) natural enemy populations present in agricultural ecosystems and (ii) parasitoids and predators released into crops as biological control treatments [124,125].

Although they are considered to be less toxic than some groups of synthetic chemical insecticides (e.g., organophosphates, carbamates and neonicotinoids), there is some concern about the potential negative health impacts of exposure to pyrethrins and spinosad residues [111,126,127].

\subsubsection{Synthetic Chemical Pesticides That Are Prohibited in Organic Farming}

Negative health effects of occupational (e.g., farmers and crop protection contractors handling pesticides) and environmental exposure to synthetic chemical pesticides are well documented, and there is also increasing evidence for negative health impacts of chronic dietary pesticide exposure [126-136].

In the EU more than 300 different synthetic chemical pesticides (herbicides, insecticides, acaricides, fungicides, plant-growth regulators and soil-disinfecting chemicals) are 
licensed and widely used for crop protection in conventional food production [128,129]. In contrast, EU organic farming regulations prohibit the use of all synthetic, chemical pesticides for crop protection and as veterinary treatments [4,111]. However, as described in Section 2.3.5 above, organic farming standards permit the use of pesticide products made from (i) mined minerals ( $\mathrm{S}, \mathrm{Cu}$ ), (ii) microbial fermentation extracts, and (iii) plant extracts $[4,111]$. In this section, we therefore summarize the currently available information of the effect of organic vs conventional production protocols on pesticide residues in crops [57,137-141].

Three comprehensive literature reviews and two meta-analyses of organic versus conventional crop composition data reported that levels of pesticide residues are substantially lower in organic than conventional foods, and concluded that organic food consumption may be one strategy to reduce dietary exposure to pesticides and associated health risks $[57,137,139]$. For example, the most recent meta-analysis by Baranski and co-workers [57] reported that organic crops are four times less likely to contain detectable pesticide residues than conventional crops, and that the level of pesticide contamination in conventional crops differs significantly between cereals, vegetables and fruit products (Figure 7a). Specifically, conventional fruits were found to have substantially higher pesticide loads than conventional vegetables and cereal-based foods, whereas contamination levels were similar in organic fruits, vegetables and cereal-based foods, but substantially lower than in their conventional comparators (Figure 7a). Similar results were obtained in recent retail surveys of fruits, vegetables and cereal-based foods [141], which reported that the number of different pesticide residues detected was substantially higher in conventional products, compared with organic fruit, vegetables and cereal-based food products (Figure $7 \mathrm{~b}$ ). A large retail survey of wheat flour products carried out over 3 years in the UK and Germany reported significant effects of wheat species (Triticum aestivum L. vs. T. spelta L. flour) and refining (white versus whole-grain flour) and the country in which flour samples were collected (the UK versus Germany), on pesticide residue concentrations in conventional, but not organic wheat flour, which generally contained very low pesticide residues [140] (Figure 8). Specifically, the reduction in pesticide exposure associated with organic food consumption was significantly higher with wholegrain, compared with refined flour, common wheat compared with spelt wheat flour, and in the UK compared with Germany (Figure 8).

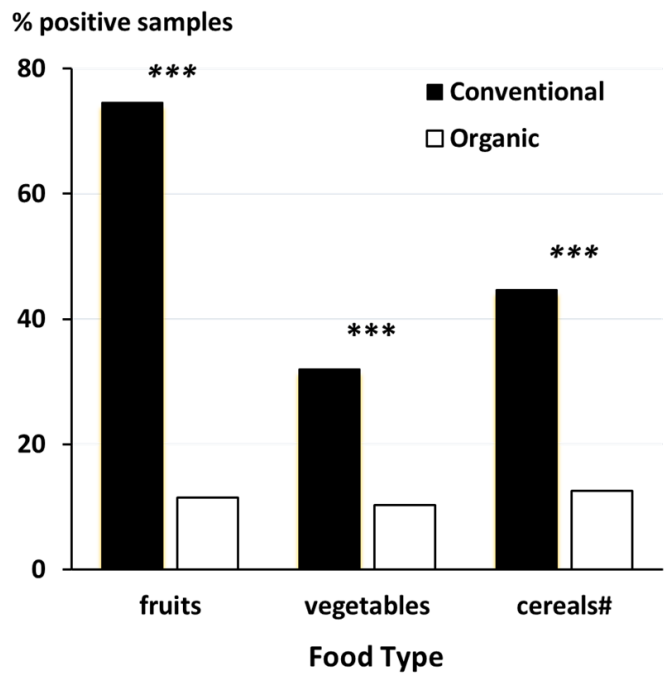

(a)

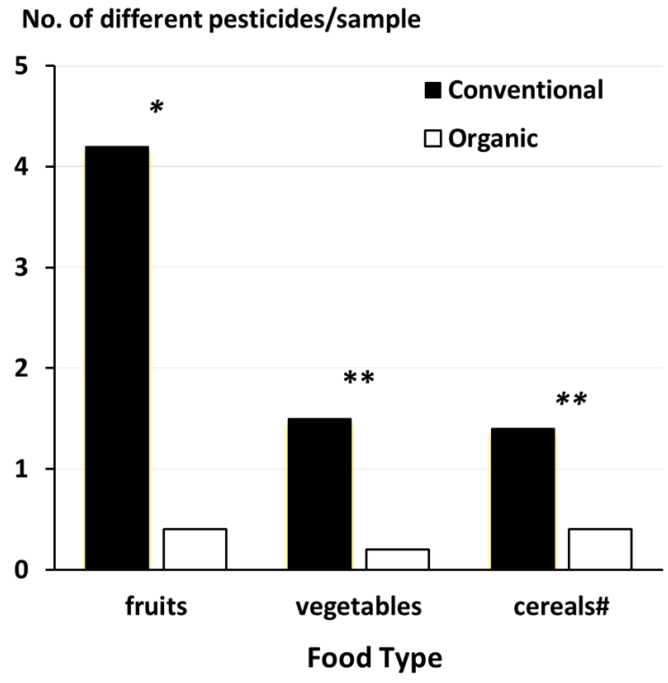

(b)

Figure 7. Effect of organic and conventional production methods on (a) the percent of samples testing positive for at least one pesticide residue. Data from [57], and (b) the number of different pesticide residues detected in fruits, vegetable and cereal-based foods. Data from [141]. \#, cereals and cereal-based food products. ${ }^{* * *}$, significant difference $(p<0.001)$; $* *$, significant difference $(p<0.01) ; *$, significant difference $(p<0.05)$; T, trend $(0.01<p<0.05)$; NS, not significant. 
These results are consistent with regulatory pesticide monitory data from Europe, which also suggest that pesticide residue levels in whole-grain cereal products, fruit and vegetables are higher than in food such as refined cereal products, and most meat and dairy products [128].

It is important to note that the concentrations of pesticides in pesticide-treated crops may also be affected by both environmental conditions and agronomic practices other than pesticide use [58,142-144]. For example, wheat produced with conventional, pesticidebased crop protection regimes had significantly higher chlormequat levels in manurefertilized plots, compared with mineral NPK-fertilized plots in the NFSC trial [58] (Figure 9). Chlormequat is a plant-growth regulator that is licensed in the EU only for use in cereals (especially wheat) to prevent lodging. The higher chlormequat residues in manure-fertilized crops are thought to be due to the 1-2-week earlier wheat grain maturity and senescence observed in manure, compared with NPK-fertilized wheat crops, which shortens the period available for the metabolism of chlormequat by the plant [58]. Compound feeds made from manure-fertilized cereal, potato, carrot and onion crops grown in the NFSC trials and used in animal dietary intervention studies (see Section 2.1) therefore contained significantly higher concentrations of chlormequat, than feeds produced with mineral NPK fertilizer [142].

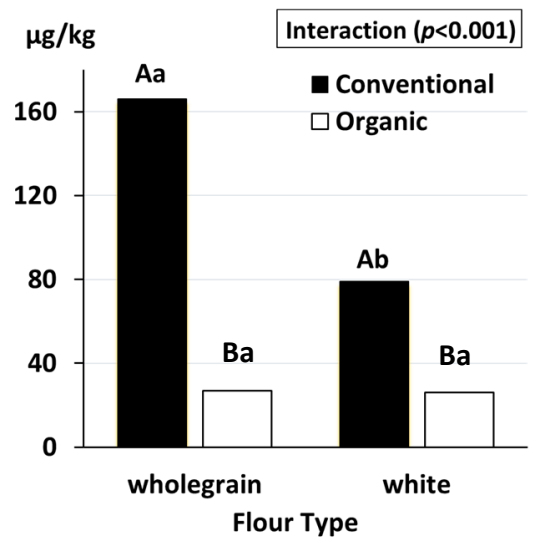

(a)

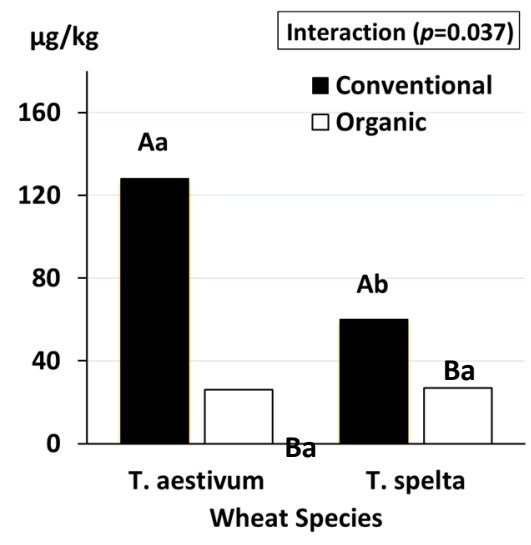

(b)

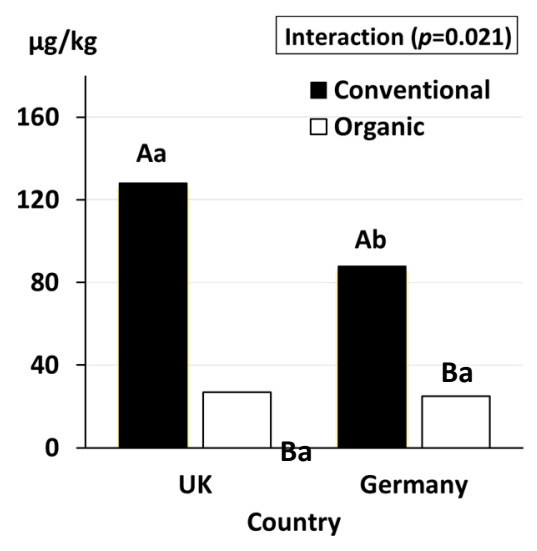

(c)

Figure 8. Effect of organic and conventional production methods on the total pesticide residue concentrations in (a) wholegrain and white/refined wheat flour, (b) spelt and common wheat flour and (c) wheat flour samples produced in the UK and Germany). Data from [140]. Means/bars for the same production system (=same color) labelled with the same lower-case letter and means/bars for the same flour types, wheat species or country labeled with the same capital letters are not significant different $(p<0.05)$.

In contrast, concentrations of the insecticide aldicarb and the herbicide diquat were lower in compound feeds made from manure-fertilized crops, compared with mineral NPK-fertilized cereal, potato, carrot and onion crops, when feeds made from pesticidetreated crops were compared $[58,143]$. Aldicarb is an insecticide applied as granules to soils for soil-borne pests, and nematode control and was only used in potato crops, whereas Diquat is a semi-selective herbicide that was applied in potato and vegetable crops in the NFSC trials [58,143]. Soil-applied herbicides and insecticides are known to be absorbed by soil organic matter, and aldicarb metabolism in topsoil is thought to be mainly by microbial activity [144,145], which is known to be higher in soils receiving regular organic fertilizer inputs [78,146-148]. The lower levels of diquat and aldicarb found in crops from manure-fertilized soils are therefore thought to have been due to higher levels of microbial metabolism and/or absorption to soil organic matter, but this was not confirmed by soil analyses in the NFSC trials [58]. 


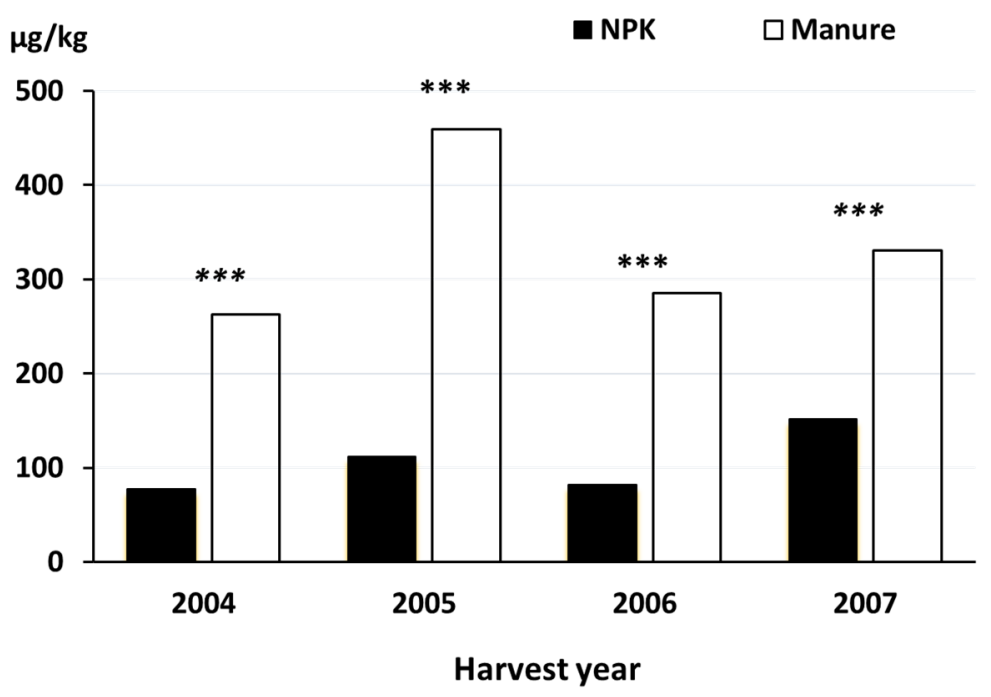

Figure 9. Effect of fertilization regimes (manure versus mineral NPK at the same total N-input level) on chlormequat residues in wheat grain produced in NFSC trial plots managed with conventional, pesticide-based crop protection. Data from [58]. ${ }^{* *}$, significant difference $(p<0.001)$. The maximum residue level (MRL) set by the EU for chlormequat residues in wheat grain is $7 \mathrm{mg} / \mathrm{kg}$.

The use of pesticides and especially herbicides can affect the metabolism and physiology of crop plants in many different ways [149]. For example, herbicides were shown to inhibit photosynthesis and energy metabolism and/or inhibit root growth and nutrient uptake from soil [149-154]. This may lead to an increased susceptibility to crop diseases and lower concentrations of nutritionally desirable phytochemicals involved in photosynthesis (e.g., carotenoids), and mineral micronutrients (e.g., $\mathrm{Ca}, \mathrm{Mg}, \mathrm{Fe}, \mathrm{Zn}$ ) in plants [149-154]. For example, the negative effects of glyphosate-based herbicides (GBHs, the most widely used crop protection products globally) on crop health and nutritional composition were recently reviewed [155] and include:

- "Impairment of the innate physiological defenses by interruption of the shikimic acid pathway";

- "Interference with rhizosphere microbial ecology (in particular, GBHs have the potential to enhance the population and/or virulence of some phytopathogenic microbial species in the crop rhizosphere)";

- $\quad$ "As yet incompletely elucidated reduction in the uptake and utilization of nutrient metals by crops".

\subsection{Crop Breeding and Selection}

The first organic and "low-input" farming-focused breeding/selection programs started in the late 1990s, and for many crop species there are still no organic-farmingspecific breeding programs [8-11,156,157]. As a result, the majority of crop varieties used in organic farming were developed for conventional farming, and are therefore thought to lack important traits required for optimum crop yield, health and/or quality in organic systems [7-11,156-158].

However, organic farmers tend to use (i) different and often older, traditional cultivars and/or (ii) varieties with higher disease resistance and/or competitiveness against weeds [7-11]. Many organic farmers also prefer to use open-pollinating varieties rather than hybrids, because they perceive them as having better sensory quality, or because they want to be able to save seed for the next season $[10,158]$.

The approaches, standards and philosophy of organic plant breeding have recently been reviewed [156-158] and are therefore not described in detail here. However, it is important to note several important characteristics of organic breeding programs: namely that (i) breeding and selection are farmer-participatory, (ii) selection is carried out under low-input and/or organic farming conditions, and (iii) maintenance breeding/seed 
production is carried out in contrasting pedoclimatic environments to optimize local adaptation [156-158].

Most breeding and variety selection programs for organic farming have focused on crop species where modern conventional varieties were found to perform poorly in organic systems, and/or where the combination of traits desired by organic farmers are very different from those delivered by conventional breeding programs (e.g., for wheat, brassicas such as broccoli [Brassica oleracea L. cultivar group italica] and more recently soya [Glycine max (L.) Merr.]) [10,13,152,153]. For example, conventional wheat breeding programs have focused on reducing the straw length to minimize lodging risk and increase grain-yield potential in high mineral NPK and pesticide input systems $[13,153]$. In contrast, organic wheat breeding programs have focused on the delivery of varieties with longer stems/straw, high levels of disease resistance, competitiveness against weeds, and the ability to produce a high protein content under low input and/or organic farming conditions $[13,153]$.

There is increasing evidence for significant differences in the nutritional composition between modern varieties/hybrids developed for the conventional farming sector and (i) varieties developed in breeding programs for the low-input or organic farming sector, and/or (ii) older and/or traditional varieties selected or preferred by organic farmers. Results from studies with wheat, table grapes (Vitis vinifera L.) and butternut squash (Curcurbita L.) are described, as examples, in separate sections below.

\subsubsection{Wheat}

Studies with common wheat (T. aestivum) in the US and spelt wheat (T. spelta) in Crete reported that modern, short-straw varieties have lower mineral micronutrient (e.g., $\mathrm{Cu}, \mathrm{Fe}$, Se and/or $\mathrm{Zn}$ ) concentrations in the grain than traditional, long-straw varieties $[13,40]$. In a UK study with common wheat (T. aestivum), a long-straw variety from a Swiss organic breeding program was also shown to have higher levels of rust resistance, and higher phenolic concentrations than a modern, short-straw variety developed for conventional production [13]. The study identified strong positive associations between foliar phenolic concentrations, and both rust and Septoria disease severity [13].

In contrast, in field experiments with spelt wheat (T. spelta) in Crete, a modern shortstraw spelt variety had significantly higher grain phenolic levels than two, traditional long-straw "Urspelt" varieties and an intermediate straw-length variety developed for the organic farming sector [40].

Overall, the available evidence suggests that longer-straw wheat varieties, favored by organic farmers, have higher levels of mineral micro-nutrients, whereas there is no clear trend for a correlation between straw length and phenolic concentrations.

It is interesting to note that (i) the lower levels of lodging observed with manure, compared with mineral NPK fertilizer inputs, makes it less risky to use longer-straw varieties in organic farming systems, and (ii) the greater competitiveness against weeds and higher grain protein levels in longer straw varieties are a benefit in organic farming systems, which prohibit the use of water-soluble mineral $\mathrm{N}$-fertilizers to increase grain protein levels, and herbicides to reduce weed competition [13,40].

\subsubsection{Grapes}

A group of recent studies comparing the nutritional composition of table grapes (which included a comprehensive literature review/meta-analysis of retail surveys in the UK and farm surveys in Crete) also identified significant interactions between variety choice and the production system. These studies compared the effect of production systems (organic versus conventional), growing environments (South Africa versus the Mediterranean) and different grape types/varieties on antioxidant activity, and the phenolic concentrations in table grapes $[12,19,60]$. They reported grape type (white, red and black) and/or variety as the strongest driver for antioxidant and phenolic levels in grapes and that, overall, organic production was found to result in higher phenolic levels in grapes, compared with 
conventional production. However, when data from all grape varieties assessed in the UK retail survey were compared, only organic white grapes, but not red and black grapes, were shown to have significantly higher antioxidant capacity compared with their conventional comparators [12] (Figure 10a). When the results obtained for individual grape varieties were compared, both the retail and farm survey-based data showed (i) no significant effect of production systems for the majority of varieties, and (ii) higher levels of antioxidants and/or phenolics in organic grapes for some varieties (see Figure 10b for results from the farm survey). It is important to point out that the reasons for the contrasting effects of production systems on different grape types/varieties are currently unknown $[12,19,60]$.

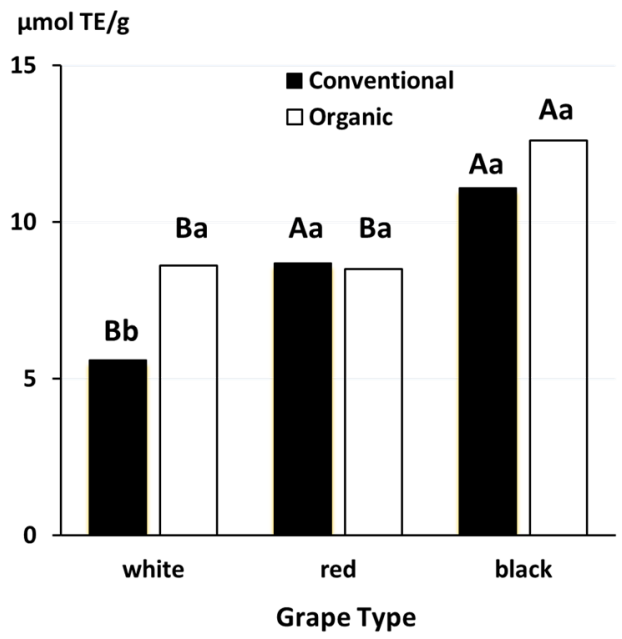

(a)

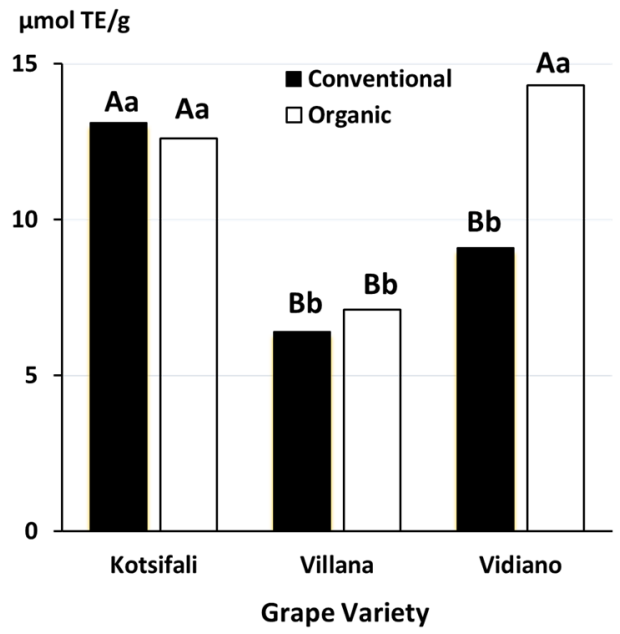

(b)

Figure 10. Effect of organic and conventional production methods on antioxidant activity/capacity (TEAC) in (a) white, red and black table grape analyses, as part of a UK retail survey, data from [12] (2-factor ANOVA detected a significant interaction ( $p=0.025)$ between grape type and production systems) and $(\mathbf{b})$ grapes of three indigenous, traditional grape varieties analyzed as part of a farm survey in Crete, Greece, data from [19] (2-factor ANOVA detected a significant interaction ( $p=0.016)$ between grape variety and production systems). Means with the same capital letter for the same production system and means with the same lower-case letter for the same grape type or variety are not significantly different according to Tukey's contrasts $(p<0.005)$.

\subsubsection{Butternut Squash}

A recent field experiment with butternut squash carried out in Spain [159] reported significant interactions between variety (two modern F1 hybrids developed for conventional production were compared) and production systems (manure versus mineral NPK fertilizer) for a range of nutritionally relevant parameters (Table 2; Figure 11).

When the main effects of production systems were compared, organic management resulted in significantly higher $\mathrm{Zn}, \mathrm{Mn}$ and tocopherol, but lower folate and $\beta$-carotene concentrations and lower antioxidant capacity. When the main effects of variety were compared, Pluto had higher $\mathrm{Fe}, \mathrm{Mn}$, folate and amino acids, but lower concentrations of tocopherol than Ariel (Figure 11; Table 2).

Principle component analyses suggested that the two F1-hybrids had contrasting nutritional profiles when grown with organic production methods, but had very similar nutritional profiles when grown conventionally. It is important to point out that both F1-hybrids were developed for conventional farming systems [159] and the fertilizer inputs used in both the organic and conventional systems were very high (Table 2). 
Table 2. Effect of variety/F1-hybrid (Ariel versus Pluto) and production systems (conventional vs. organic) on antioxidant activity/capacity and concentrations of nutritionally relevant vitamins, total phenolics and amino-acids (values shown are main effect means; results are from a single field experiment in Spain; data from [159].

\begin{tabular}{|c|c|c|c|c|c|c|}
\hline \multirow[b]{2}{*}{ Parameter Assessed } & \multicolumn{2}{|c|}{ Variety } & \multicolumn{2}{|c|}{ Production Systems } & \multicolumn{2}{|c|}{ ANOVA ( $p$-Values) } \\
\hline & Ariel & Pluto & Conventional $^{1}$ & Organic $^{2}$ & Variety & $\begin{array}{l}\text { Production } \\
\text { System }\end{array}$ \\
\hline $\begin{array}{c}\text { Vitamins (Vit) } \\
\text { water soluble }(\mu \mathrm{g} / \mathrm{g} \text { FW) } \\
\text { folate }\left(\text { Vit } \mathrm{B}_{9}\right) \\
\text { fat soluble }(\mu \mathrm{g} / \mathrm{g} \text { FW })\end{array}$ & 0.25 & 0.31 & 0.30 & 0.26 & $<0.001$ & $<0.001$ \\
\hline$\beta$-carotene (provitamin A) & 2.04 & 3.67 & 3.63 & 2.24 & $<0.001$ & $<0.001$ \\
\hline total carotenoids & 39.53 & 34.54 & 38.38 & 35.95 & NS & NS \\
\hline tocopherol (Vit E) & 5.60 & 1.65 & 1.28 & 5.50 & $<0.001$ & $<0.001$ \\
\hline total phenolics ( $\mu \mathrm{g}$ GAE/g) & 199 & 195 & 205 & 191 & NS & NS \\
\hline $\begin{array}{l}\text { antioxidant activity ( } \mu \mathrm{g} \text { TE/g) } \\
\text { amino acids (AA; } \mathrm{mg} / 100 \mathrm{~g})\end{array}$ & 257 & 281 & 286 & 254 & NS & $<0.05$ \\
\hline total essential AA & 204 & 348 & 233 & 324 & $<0.001$ & $<0.05$ \\
\hline total non-essential AA 4 & 430 & 792 & 593 & 659 & $<0.001$ & NS \\
\hline
\end{tabular}

Significantly higher means are shown in bold. NS, not significant; GAE, gallic acid equivalents; TE, ${ }^{1}$ crop protection was according to recommendations for conventional farmers Spain; mineral fertilizer inputs were $750 \mathrm{~kg} / \mathrm{ha}$ of N:P:K (8:15:15) pre-planting, plus $300 \mathrm{~kg} / \mathrm{ha}$ of calcium ammonium nitrate at thinning (3-4 leaf stage); ${ }^{2}$ crop protection was according to organic farming practices in Spain; organic fertilizer inputs were $25 \mathrm{t} /$ ha of cattle manure pre-planting, plus $500 \mathrm{~kg} /$ ha of dehydrated chicken manure at thinning (3-4 leaf stage); ${ }^{3}$ sum of histidine, arginine, threonine, valine, lysine, isoleucine, leucine, phenylalanine; ${ }^{4}$ sum of aspartic acid, serine, glutamic acid, glycine, alanine, proline and tyrosine.

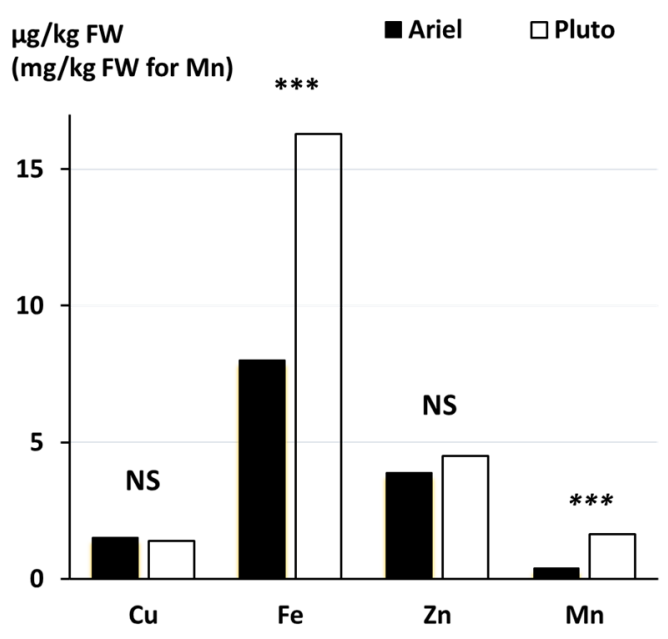

(a)

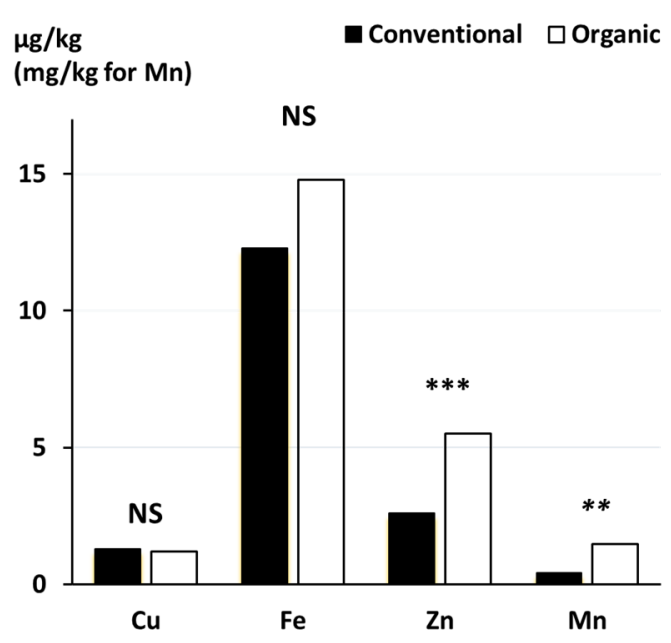

(b)

Figure 11. Effect of different F1-hybrid (Ariel F1 versus Pluto F1) and production systems (conventional vs organic) on mineral micronutrient concentrations $(\mathrm{Cu}, \mathrm{Fe}, \mathrm{Zn}, \mathrm{Mn})$ in butternut squash (values shown are main effect means; results are from a single field experiment in Spain; data from [159]. ${ }^{* * *}$ significant difference $(p<0.001) ;{ }^{* *}$ significant difference $(p<0.01)$; NS, not significant.

\subsection{Confounding Effects of Pedoclimatic Background Conditions}

When comparing the effects of the agronomic protocols used in organic and conventional farming on crop yield and quality parameters, it is important to consider that (i) both productivity and nutritional composition profiles of crops can be affected by a wide range of soil, landscape and climatic factors and (ii) that these environmental factors may interact with, and confound, the effects of specific agronomic parameters, crop genetics and/or production systems [160]. 
Results from the NFSC trials [58] demonstrated that it is not possible to make accurate conclusions regarding the effect of the production system (organic versus conventional) and specific agronomic practices (e.g., fertilization, crop protection and rotational design) on crop quality parameters, unless the environmental variability is considered in the study design. Specifically, this means that field experiments and surveys need to be repeated in at least three production seasons and/or locations with contrasting pedoclimatic conditions, before (i) reliable estimates of the overall effects of agronomic practices or production systems can be made, (ii) interactions between agronomic and environmental parameters can be identified, and (iii) the relative importance of environmental versus agronomic drivers on nutritional quality parameters can be analyzed/modelled appropriately by redundancy analyses (RDA) [58].

Specifically, results from the NFSC trials $[13,20,33,50,58,65]$ demonstrated that seasonal variation in climatic conditions was a significant driver for crop composition and confounded the effects of rotation, variety choice, fertilization and crop protection $[13,58]$. For example, for winter wheat, RDA of data from four growing seasons confirmed that both climatic conditions and agronomic parameters were significant explanatory variables/drivers for leaf phenolic concentrations (Figure 12). Air temperature and organic fertilization regimes were identified as positive drivers for phenolic concentrations, whereas conventional fertilization regimes and high $\mathrm{N}$ and $\mathrm{P}$ availability were identified as significant negative drivers for phenolic concentrations [33] (Figure 12). Interestingly, grass-clover ley pre-crops, which result in higher $\mathrm{N}$-availability, were also identified as a negative driver for phenolics (Figure 3), which is consistent with studies that reported negative correlations between $\mathrm{N}$-availability and phenolic concentrations in crops [13,33,52-54].

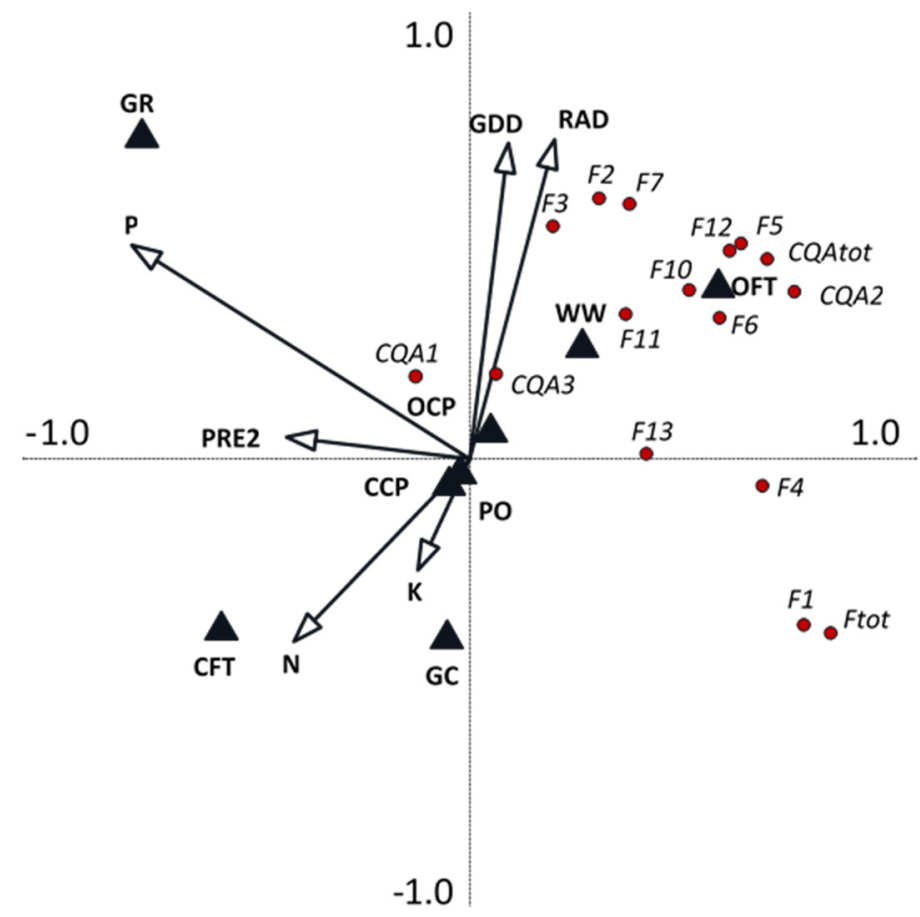

Figure 12. Biplot derived from redundancy analysis showing the relationship between weather conditions (in the 14-15-week period before leaf samples were taken in 2005, 2007, 2008 and 2009), N, P and K availability (estimated from flag leaf N P and K content at growth stage 50 (GS50), and agronomic management explanatory variables/drivers and phenolic compounds in wheat leaves at GS50, data from [33]. Axis 1 explains $60 \%$ and axis 2 a further $18 \%$ of the variation. Continuous explanatory variables: $\mathrm{N}, \mathrm{N}$-availability $(p=0.064) ; \mathrm{P}$, phosphorus availability $(p=0.002) ; \mathrm{K}$, potassion availability $(p=0.278)$; GDD, air temperature $(p=0.0024)$; RAD, radiation $(p=0.002)$; PRE2, precipitation $((p=0.090)$. Fixed explanatory variables: CFT, conventional fertilization $(p=0.002)$; OFT, organic 
fertilization $(p=0.002)$; CCP, conventional crop protection $(p=0.160), \mathrm{OCP}$, organic crop protection $(p=0.160) ; \mathrm{GC}$, pre-crop grass-clover ley $(p=0.004) ; \mathrm{GR}$, pre-crop rye-grass ley $(p=0.920) \mathrm{PO}$, pre-crop potato $(p=0.312), \mathrm{WW}$, pre-crop winter wheat ( $p=$ undefined). Phenolic acid response variables: $\mathrm{c} 1$ to $\mathrm{c} 3$, different individual chlorogenic acid derivatives; $\mathrm{f} 1$ to $\mathrm{f} 13$, different individual flavonoids; $\mathrm{CQA}_{\text {tot }}$, total chlorogenic acid derivatives; $\mathrm{F}_{\text {tot }}$, total flavonoids.

\section{Effects of Organic Crop Consumption on Health Markers and Disease Incidence}

Systematic literature reviews and meta-analyses of comparative crop composition data reported that organic crops have on average:

- Lower concentrations of pesticides and cadmium;

- Higher antioxidant capacity and concentrations of a range of individual phytochemicals with antioxidant activity (e.g., phenolics; other plant defense compounds) [56,57,127,139]

When compared with conventional crops. In addition, recent retail surveys and meta-analyses of published mycotoxin contamination data in cereals suggest that organic whole-grain, and to a lesser extent, refined cereal products have on average:

- Higher concentrations of mineral micronutrients;

- Slightly lower concentrations of certain Fusarium mycotoxins [39,40,59].

There is general agreement that the presence of pesticides, cadmium and mycotoxin residues (which are higher in conventional crops), is nutritionally undesirable and EUregulators have set maximum residue levels (MRL) for pesticides and maximum contamination levels (MCL) for mycotoxins and toxic metals such as cadmium [161,162]. However, since most conventional crop samples contain levels of pesticide residues, cadmium or mycotoxins that are below the MRLs or MCLs set by regulators, there is considerable uncertainty and controversy on whether, and to what extent, the higher concentrations found in conventional foods, compared with organic foods have a significant health impact $[66,128-139]$.

In contrast, the higher dietary intake of phytochemicals with antioxidant activity (e.g., polyphenols, carotenoids) and mineral micronutrients, such as Zn and Se, with plant foods is widely considered to be nutritionally desirable, and thought to be one of the main reasons for the health benefits associated with diets (e.g., traditional Mediterranean diets) higher in whole-grain, fruit and vegetables [163-167]. However, although the benefits of increasing whole-grain, and fruit and vegetable consumption on phytochemical and mineral micronutrient intake and public health are well documented [163-167], there is considerable controversy on whether, and to what extent, changing to organic food consumption can affect phytochemical and mineral micronutrient intake and associated health impacts [168,169].

In this section, we therefore summarize the currently available evidence for: (i) effects of organic crop consumption on health-related physiological parameters detected in dietary intervention studies with animals (Section 4.1); (ii) associations between organic food consumption and disease incidence identified in human cohort studies (Section 4.2); (iii) additive/synergistic health and food security benefits of increased whole-grain, fruit and vegetable intake with organic instead of conventional foods (Section 4.3).

\subsection{Evidence from Animal Dietary Intervention Studies}

A small number of animal dietary intervention studies have compared effects of organic and conventional feed consumption on health-related physiological markers: see Velimirov et al. [170] and Średnicka-Tober et al. [142] for detailed reviews of these studies. All reported some significant differences in growth and/or physiological parameters (e.g., body composition, plasma antioxidant and hormone levels, immunoglobulin concentrations and/or immune system responsiveness) between animals raised on conventional and organically produced feed [142,170]. However, the parameters assessed and the analytical methods, animal species and/or experimental designs differed between studies, mak- 
ing it difficult to identify consistent trends and draw conclusions about potential health impacts [142,170]. The only relatively consistent trend found was for immune system responsiveness. Six out of eight studies (one with rabbits, two with chickens, two with rats and one with mice) reported greater responsiveness with organic feeds, whereas two studies (one with pigs and one with rats) reported no significant effect of feed type, and none of the studies reported greater responsiveness with conventional feeds [142,170].

Two of the published dietary intervention studies with rats had a factorial design, and investigated effects of and interactions between contrasting fertilization (manure versus mineral NPK) and crop protection regimes (with and without synthetic chemical pesticides) used in organic and conventional farming on growth, hormone and immune system parameters (Figure 13) [142,143].
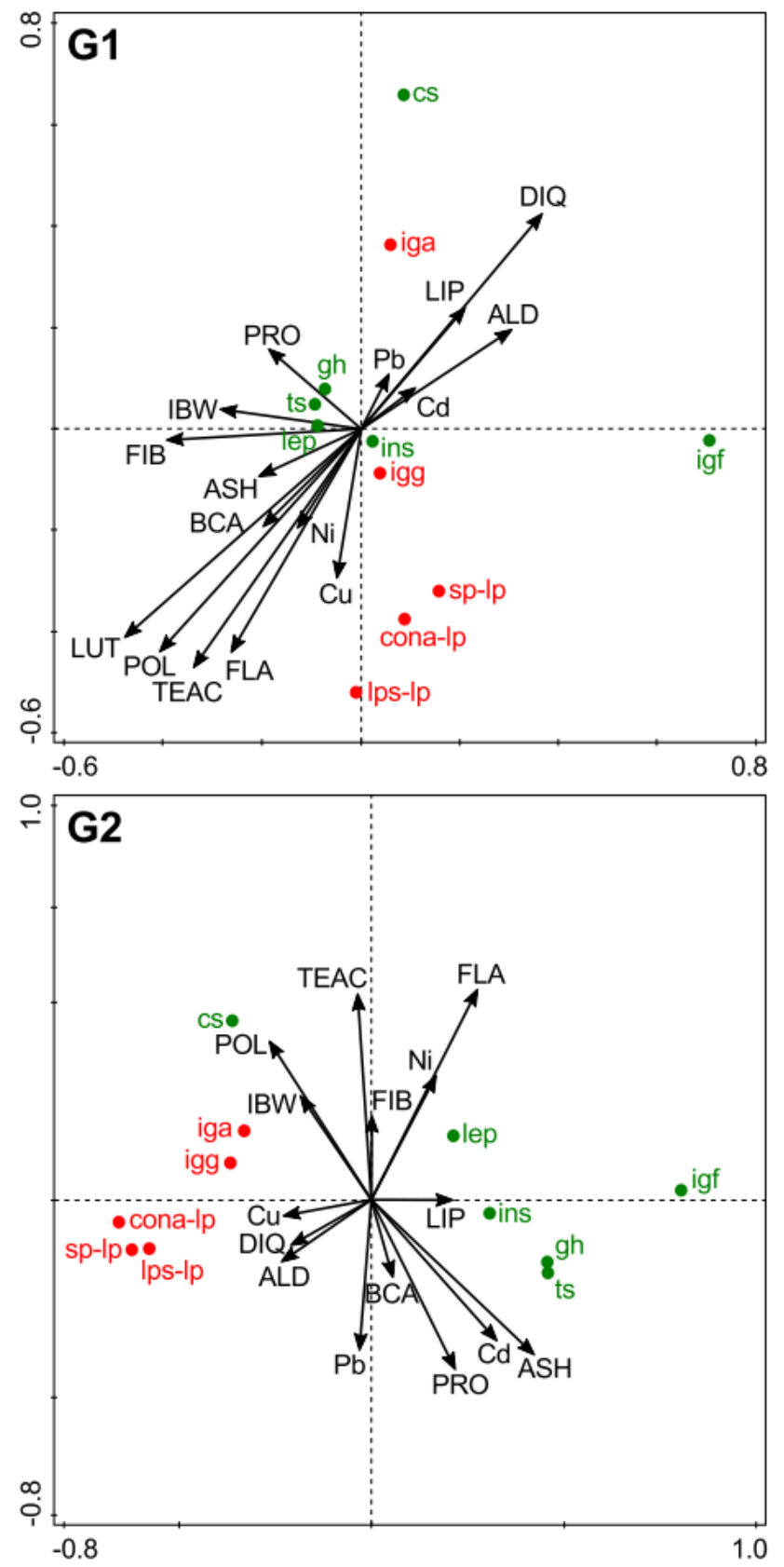

Figure 13. Biplot derived from the redundancy analysis (RDA) showing the relationships between the concentrations of experimental feed components/parameters (continuous explanatory variables) 
and selected hormones and immunological parameters (response variables) in the first (G1) and second (G2) generation of rats, data from [143]. ASH, ash; LIP, lipids; PRO, protein; FIB, fiber; BCA, $\beta$-carotene; FLA, flavonols; LUT, lutein; POL, polyphenols; $\mathrm{Cu}$, copper; ALD, aldicarb and DIQ, diquat; $\mathrm{Cd}$, cadmium; $\mathrm{Ni}$, nickel; $\mathrm{Pb}$, lead; TEAC, feed antioxidant activity; IBW, initial body weight of rats at weaning, cs, corticosterone; gh, growth hormone; igf, insulin-like growth factor 1; lep, leptin; ins, insulin; ts, testosterone; iga, immunoglobulin A; igg, immunoglobulin G; sp-lp, spontaneous lymphocyte proliferation; cona-lp, concanavalin A-stimulated lymphocyte proliferation; lps-lp, lipopolysaccharide-stimulated lymphocyte proliferation.

Results from both studies suggested that the relatively small changes in dietary intakes of (i) polyphenols and other phytochemicals, (ii) endocrine-disrupting pesticides, (iii) toxic metals $(\mathrm{Cd}, \mathrm{Pb})$ and/or (iv) fiber, lipids and protein resulting from pesticide and/or mineral NPK fertilizer use, have complex and often interactive effects on endocrine, immune systems and growth parameters in rats (Figure 13). Moreover, both studies reported that the consumption of organic feed resulted in higher levels of lymphocyte proliferation (a marker for immune system responsiveness) when compared with the consumption of conventional feeds [142,143].

There is mounting evidence that maternal dietary factors (including severe nutrient deficiencies, intakes of endocrine-disrupting chemicals/pesticides, polyphenols and other phytochemicals) may result in the epigenetic programming of endocrine and immune functions, and thereby affect the risk of several diseases, including atopic disease and cancer development in subsequent generations [171-177]. One of the factorial rat dietary intervention studies therefore investigated the effects of contrasting fertilization and crop protection regimes [143] in two successive generations of rats, raised on contrasting feeds. This two-generation study demonstrated that the physiological response of rats to contrasting feed composition profiles (resulting from organic and conventional crop management practices) differed substantially between the first and second generations, which may indicate epigenetic programming and/or the development of "adaptive" phenotypes. Figure 13 shows the contrasting associations between feed composition drivers and endocrine and immune system response variables, identified by redundancy analysis in the two successive generations of rats [143].

Given that polyphenols were identified as the strongest drivers for both endocrine and immunological parameters in this two-generation rat study [143] it is important to consider that polyphenols have been shown to affect the epigenome through several mechanisms $[177,178]$. Specifically, in vitro studies reported that catechins (a group of polyphenols found in green tea) significantly reduced DNA methylation levels of gene promoters involved in DNA repair, and thereby restored their functions [178]. Moreover, the consumption of fruit with a high phenolic content (e.g., black raspberry) was reported to result in DNA demethylation of gene promoters involved in colorectal cancer [179]. Epigenetic regulatory mechanisms are therefore thought to, at least partially, explain cancerpreventing effects linked to the consumption of (poly)phenolic-rich fruits, vegetables and whole-grain cereals $[180,181]$.

It is important to note that the effect of feed composition differences associated with contrasting farming practices has only been investigated in a small number of animal studies, and that there are no studies in which health outcomes have been measured. Before drawing a conclusion about potential health impacts, it is therefore important to carry out additional multi-generation studies with rodents or other animal models to confirm the results of the studies described above. Moreover, it will be important to (i) expand the assessment to other health-related physiological markers (e.g., oxidative stress and inflammation-related markers) and (ii) include obesity, diabetes, cancer and other disease model rodent strains [181-184] in experiments, to allow health outcomes of relevance to the human population to be investigated. 


\subsection{Evidence from Human Dietary Intervention and Cohort Studies}

Several dietary intervention studies with humans and some human cohort studies have assessed the effect of organic versus conventional food consumption on urinary excretion of pesticide residues, but there is limited data on urinary excretion of other health relevant compounds (e.g., phenolics, other phytochemicals, antioxidants and mineral micronutrients). These studies have consistently shown that organic food consumption results in significantly lower exposure to a range of pesticides, but identified no or only very small effects on the urinary excretion of other health relevant compounds [141,168,169,185-190]; this evidence has been described and discussed in detail in a recent systematic review by Vigar et al. [169].

The most controlled (during the 2-week intervention period participants consumed either only certified organic or only conventional foods) and comprehensive (in terms of the range of pesticides monitored) dietary intervention study estimated that changing to organic food consumption can reduce total pesticide exposure by more than $90 \%$ [141]. Interestingly, the same study also found that switching from habitual Western diets (with high meat and low fruit and vegetable consumption) to a healthy, traditional Mediterranean diet with low meat, and high fruit and vegetable consumption, resulted in 3-4 times higher insecticide and organophosphate exposure [141]. These results suggest that the effects of changing to organic food consumption, considering dietary pesticide intake and the associated potential negative health impacts, may be greater with a healthy diet.

The finding that organic food consumption can significantly reduce pesticide exposure is thought to be of relevance for human health, because there is increasing scientific evidence for the negative impacts of chronic dietary pesticide exposure, especially compounds that are suspected or proven to be neurotoxic and/or endocrine-disrupting chemicals (EDCs) [129-136]. Negative health effects of occupational and environmental exposure to pesticides are also well documented and predicted to increase in the future $[129,130,132-136,191]$. For example, a recent market analysis for pharmaceutical products that are used to treat acute carbamate and organophosphate poisoning in farmers and contractors that handle pesticides have predicted a significant increase in demand, especially in developing and underdeveloped countries, due to a predicted increase in pesticide use in these countries [191].

It should be pointed out that the European Commission and other government regulators set maximum residue limits (MRLs) for pesticides in food crops that are orders of magnitude below the concentrations that result in measurable toxicity symptoms in animal studies [128,161]. Regulators therefore consider pesticide residues below the MRLs as safe for consumers $[128,129,161,192-194]$. However, regulatory residue monitoring in Europe continues to find that a significant proportion of crop samples contain pesticide residues above the MRL [128], and there is increasing concern about the efficacy of the current regulatory pesticide approval system and the "safety" of pesticide residues below MRLs set by regulators [134-136].

One of the main concerns is that the current regulatory toxicological safety testing is based on Paracelsus' 15th century assumption that "toxic effects" are greater at higher rather than lower doses ("the dose makes the poison"). Pesticide safety testing is therefore usually based on one-generation animal studies (usually rodents) that assess the effect of high and moderate doses of chemicals. Specifically, these tests determine the frequency and severity of death, disease symptoms, fetus malformations and/or low birth weights. Results are then linearly extrapolated downwards and MRLs set at doses that are assumed to be safe [129,132,193-195].

However, many of the most widely used pesticides are suspected or confirmed endocrine-disrupting chemicals (EDCs), which, like hormones, have (i) activity at very low doses and (ii) U-shaped and/or inverted U-shaped, non-monotonic dose-response curves [132-134,195-197]. This makes it impossible to predict negative health impacts associated with low-level dietary exposure based on the current regulatory, animal model-based toxicity tests. Moreover, ECDs are increasingly recognized to lead to epigenetic alterations 
and programming, which may eventually lead to an increased incidence in a variety of diseases (including obesity, type-2 diabetes, immune abnormalities and cancer) later in life, or in subsequent generations [132,195-198]. Epigenetic effects of ECDs can therefore only be accurately identified via extensive, multigenerational animal studies, but such tests are not usually required as part of standard regulatory pesticide safety evaluation protocols [195-198]. As a result, there is an urgent need to address these deficiencies, given the "health" and "societal" costs that may result from chronic exposure to EDCs both in Europe and globally $[199,200]$.

There is also concern about the relatively high MRLs set by the EU for some widely used pesticides. For example, MRLs for chlormequat $\left(7 \mathrm{mg} \mathrm{kg}^{-1}\right)$ and glyphosate $\left(10 \mathrm{mg} \mathrm{kg}^{-1}\right)$ are more than 10 times higher than those set for most other pesticides $\left(0.01-0.4 \mathrm{mg} \mathrm{kg}^{-1}\right)$ licensed for use in Europe [141,161,201,202]. In this context, it is important to consider that both pesticides are suspected endocrine-disrupting chemicals [203] and glyphosate was recently classified as a probable carcinogen [204].

Another limitation of the current regulatory toxicological evaluations is that they only require testing of individual active compounds, whereas testing of formulated products and combinations of pesticides is not usually required [129,132,193-195]. Moreover, the reliance of regulators on industry-commissioned (rather than independent) toxicological evaluations has recently been criticized $[205,206]$.

A recent systematic review reported that there have been no controlled dietary intervention studies/clinical trials in which the effects of organic versus conventional food production on health outcomes has been studied [169]. However, there is increasing evidence from human cohort/epidemiological studies that organic food consumption is associated with significantly lower risks of a range of diseases including overweight/obesity [207], metabolic syndrome [208], certain cancers [209,210], hypospadias [211,212] pre-eclampsia [213], eczema [214] and middle ear infections (otitis media) [215]. This evidence has been discussed in detail in a recent systematic review by Vigar et al. [169].

Associations between disease incidence and pesticide exposure were only assessed in one of these observational studies, which found that the presence of metabolites of triazine herbicides in urine was positively associated with recurrent middle ear infections in infants $[169,215]$. It is important to note that there are now two European studies from France and the UK, which have reported that organic food consumption results in a lower incidence of non-Hodgkin lymphoma (NHL) $[209,210]$ and that observational evidence for positive associations between NHL and exposure to organophosphates were the main reasons why glyphosate and other organophosphates are now as classified as probable carcinogens [204].

Lower pesticide exposure from fruit and vegetable consumption was recently found to be associated with improved reproductive health parameters in both men and women $[216,217]$. Similarly, a reduced incidence of breast cancer among postmenopausal women in the NutriNetSanté cohort was linked to (i) low dietary exposure to synthetic pesticides such as chlorpyriphos, imazalil, malathion and thiabendazole [218], and (ii) high organic food consumption [210].

However, although both animal dietary intervention studies and observational research suggest that lower pesticide exposure may at least partially explain the health benefits associated with organic food consumption, there is still considerable uncertainty, whether and to what extent dietary pesticide exposure is responsible for the positive health impacts linked to organic food intake [169]. This uncertainty is mainly due to the lack of corroborating evidence from clinical trials, but also the finding that organic and conventional food consumers differ in other lifestyle parameters, which may have confounded results [169]. For example, organic consumers were reported to do more exercise and have healthier diets [219-221]. It is also important to consider that meta-analyses of comparative food composition data and dietary intervention studies with animal models suggest that other composition parameters (e.g., higher phenolic, omega-3 fatty acid, minerals and antioxidants, and lower cadmium intakes with organic foodss) may also have contributed 
to the health impacts associated with organic food consumption in observational studies with humans $[57,142,143,222]$ (see also Section 3.1 above).

There is also uncertainty about the potential health impacts of higher nitrate and iodine intakes associated with conventional food, compared with organic food consumption $[57,168,169,222]$, since these compounds have been linked to both positive and negative effects on human health [223-226].

\subsection{Evidence for Interactions between Diet and Food Type (Organic vs. Conventional)}

\subsubsection{Nutrition and Health}

It is generally accepted that unbalanced habitual Western diets have significantly contributed to the increase in overweight/obesity, type 2 diabetes, metabolic syndrome, coronary heart disease and certain cancers in Europe and North America [164,166,221,227]. The health benefits of increasing fruits, vegetables and whole-grain consumption are also well-documented, and there is increasing evidence that they are, at least partially, due to increased intakes of fibre, phytochemicals and mineral micronutrient intakes associated with these foods [163-166]. European consumers are therefore advised to increase fruits, vegetables and whole-grain intakes, since consumption of all these food groups is currently below the levels recommended by the WHO in most EU countries [164-166].

However, evidence from composition analyses (see Section 2) and dietary intervention studies (see Sections 3.1 and 3.2) recommend increasing the following where conventional food products are used:

- Whole-grain consumption (resulting in a higher dietary intake of pesticides and Fusarium mycotoxins from cereal products);

- Fruit and vegetable consumption (resulting in an increased dietary intake of pesticides, in particular insecticides and organophosphates).

In contrast, results show that increasing whole-grain, fruit and vegetable consumption with organic products will: (i) substantially reduce dietary intake of nutritionally undesirable pesticides and Fusarium mycotoxin; (ii) increase the intake of nutritionally desirable phytochemicals, antioxidants and mineral micronutrients compared with the consumption of conventional products at the same energy intake level (see Section 2, Section 3.1, Section 3.2).

These findings suggest that the health benefits of following current nutritional guidelines may be greater with organic consumption than conventional food consumption. This view is supported by a recent US study, which reported evidence that the benefits of increasing fruit and vegetable consumption for the prevention of coronary heart disease is significantly greater when fruit and vegetables with low pesticide loads are consumed [227].

\subsubsection{Food Security}

The implementation of the current dietary guidelines to increase wholegrain, fruit and vegetable consumption while reducing meat, and especially red meat consumption, may also have a substantial effect on food security. Specifically, this would reduce (i) the pressure to increase yields in crop production, and thereby (ii), the use non-renewable resources (e.g., fossil fuel, for the production of mineral $\mathrm{N}$-fertilizer and pesticides, and mined $\mathrm{P}$ and $\mathrm{K}$ for the production of mineral $\mathrm{P}$ and $\mathrm{K}$ fertilizer).

A reduction in red meat consumption is thought to have the greatest potential for increasing food security because (i) a substantial proportion of cereal and legume crops are used as animal feed; (ii) the conversion of crops into livestock products results in a substantial reduction in energy/protein available for human consumption, and (iii) it may lead to a reduction in the current rate of deforestation/land clearing for feed crop and animal production $[228,229]$. For example, a recent study in the US concluded that "overall, $10 \%$ of feed calories or protein ultimately becomes consumed as meat, milk or egg calories". The study also reported that beef production has the lowest feed to food conversion ratio and estimated that by "reallocating high quality land currently used for feed production for beef into producing the same amount of calories and protein from poultry (and any extra land remaining)" 
being "used to produce the mean American diet" could produce enough food to satisfy the caloric and protein needs of an additional 120 million individuals in the US $(=1 / 3$ of the current US population) [229].

Since cereals and cereal products account for $45 \%$ of the total daily calory intake of humans globally (ranging from $25 \%$ in developed countries to $55 \%$ in developing countries) [59], increasing whole-grain cereal product consumption may also have a significant positive impact on food security. This is mainly because refining (the removal of the outer bran and germ layer of the grain during milling) not only removes a large proportion of the fiber, minerals and phytochemicals with antioxidant activity, but also between 10 and $25 \%$ of the caloric value and protein content of the grain [59,163]. It is interesting to note that organic consumers were reported to, on average, eat less meat, but more wholegrain cereal products $[219,220]$.

Considering these results, the $10-25 \%$ yield gap between organic and conventional crop production may seem irrelevant, because the successful implementation of the healthy eating guideline to reduce meat consumption alone would reduce the need to produce crop calories / protein by more than 25\% in North America and Europe [229].

Based on this evidence, it is also important to consider that the 10-25\% higher yields in intensive conventional farming can only be achieved with large inputs of non-renewable resources, in particular (i) mined minerals such as $\mathrm{P}$ and $\mathrm{K}$ fertilizers, and (ii) fossil fuels needed to produce mineral $\mathrm{N}$-fertilizer and synthetic chemical pesticides [42-46]. These inputs are already unaffordable for many farmers in developing countries, and the cost of many agrochemical inputs has been increasing more rapidly than agricultural commodity prices $[230,231]$. The input-use efficiency (yield per unit input) of mineral fertilizers have also decreased significantly over the last 40 years [42], and this is thought to be one reason why yields of most broad acre arable crops have stagnated in many developed countries in the last two decades $[232,233]$. For example, a recent study in France concluded that the marginal cost for agrochemical inputs has now reached a level where the cost of additional inputs of fertilizer does not pay off at harvest time [233].

In contrast, organic crop production is substantially less dependent on non-renewable mined mineral and/or fossil fuel-based agrochemical inputs, and would therefore be expected to sustain the current yield levels when agrochemical inputs become too expensive and/or unavailable in the future. Moreover, it is reasonable to predict that yields in intensive conventional farming will eventually decline to levels recorded in the 1920s, if just one of the main mineral fertilizers ( $\mathrm{N}, \mathrm{P}$ or $\mathrm{K}$ ) becomes unavailable, unless (i) conventional farming adopts organic farming methods, or (ii) methods that overcome the "law of the minimum" of plant nutrition are discovered [234].

\section{Conclusions}

The underlying philosophy/hypothesis of organic farming-“healthy soils generate healthy crops which lead to healthy livestock and humans" - was first formulated by Sir Albert Howard and other organic farming pioneers more than 80 years ago. This was based on the comparison and observation of different farming systems, including traditional organic matter recycling-based farming systems in India and China [235].

However, substantial scientific research effort into the impacts of organic farming on soil, crop and environmental "health" parameters only started around 30 years ago, when consumer demand and the introduction of legally binding organic farming standards resulted in a substantial expansion of organic production [1-4]. These studies demonstrated a range of benefits of organic farming on soil and crop "health" parameters, including (i) higher soil carbon and organic matter levels, biological activity and biodiversity, suppressiveness against diseases and erosion resistance, and (ii) increased resistance of organic crops against biotrophic soil-borne and foliar fungal diseases [51,63,77-87,95-107,236-240]. Organic farming was also reported to reduce negative environmental impacts of agricultural production, including (i) lower nitrate leaching, (ii) phosphorus run-off and (iii) greenhouse gas emissions per ha of farmland [237-240]. The soil, crop and environmental 
"health" benefits are therefore now widely accepted, and this has resulted in government support for the expansion of organic farming in many countries [1].

\subsection{Organic Crop Production Practices Increase the Nutritional Quality of Food Crops}

Substantial research effort into the effects of organic farming practices on the nutritional composition of crops and livestock products (milk, meat and eggs) only started around 18 years ago, with the EU-funded QualityLowInputFood (2004-2009) [58], and the first comprehensive meta-analysis of organic versus conventional crop composition data was not published until 2014 [57]. The evidence now available (reviewed in part 1) suggests that there are nutritionally relevant composition differences between organic and conventional crops and that, overall, organic plant-foods contain higher concentrations of nutritionally desirable (phenolics, other antioxidants and/or mineral micronutrients) and lower concentrations of nutritionally undesirable chemicals (pesticide residues, cadmium, and/or Fusarium mycotoxins). It is important to note that a recent scientific report for the European parliament came to the same conclusion $[139,241]$.

\subsection{Agricultural Intensification Practices have Reduced Food Quality and Safety}

The scientific evidence now available also allows many of the differences in nutritional quality to be linked to specific agronomic practices, or the combined effect of several agronomic parameters (reviewed in part 1). Most importantly, the available evidence indicates that many "innovations" (monoculture/shorter rotations, mineral $\mathrm{N}$ and $\mathrm{P}$ fertilizers, pesticides, and short-straw cereal varieties) introduced as part of the agricultural intensification (or "green revolution") have had negative effects on both crop health and the nutritional quality and/or safety of crops. Specifically, there is now substantial evidence that the use of:

- Monoculture and short rotations increase crop species-specific weed, pest and disease pressure and may lead to (a) greater dependence on synthetic chemical pesticides, (b) higher pesticide residues being present in crops, and (c) a greater risk of Fusarium infection and mycotoxin contamination of cereal grains;

- Mineral phosphorus fertilizer can (a) reduce mycorrhizal development on roots and thereby negatively affect mineral micronutrient uptake and resistance against soil-borne diseases, and (b) increase cadmium concentrations in crops;

- Mineral nitrogen fertilizer is associated with (a) a reduction in crop resistance, (b) lower concentrations of nutritionally desirable phenolics and other resistancerelated phytochemicals/antioxidants in crops, and (c) increases the risk of Fusarium infection and mycotoxin contamination in cereal grains;

- Synthetic chemical pesticides in agriculture are responsible for chronic dietary pesticide exposure and may reduce concentrations of certain nutritionally desirable phytochemicals/antioxidants and mineral micronutrients in crops;

- Modern short-straw cereal varieties, (a) are less competitive against weeds and more susceptible to certain diseases (e.g., Fusarium, Septoria), (b) have lower grain protein and mineral micronutrient concentrations, and (c) increase the risk of Fusarium mycotoxin contamination in cereal grain.

Moreover, as described in Section 3.3.2, it is likely that current yield levels of intensive conventional crop production are not sustainable, due to the high reliance on non-renewable resources, and are likely to decline in the future when essential input becomes too expensive and/or unavailable. Soil-health management based on organic matter recycling and crop fertilization methods developed by the organic farming sector may therefore become essential in maintaining future security, and allowing sustainable waste management/recycling in the future.

It is important to consider that there is also increasing evidence that the intensification of conventional livestock production had negative effects on the nutritional composition of both milk and meat [222,241-251]. For example, studies which compared low-input and/or organic with intensive conventional livestock production systems have shown 
that the increased use of (i) cereal and grain/legume-based concentrate feeds, (ii) indoor production, (iii) high-yield potential dairy breeds, (iv) selection for high milk yield within breeds, and/or (iv) robotic milking systems in conventional systems may:

- Reduce concentrations of nutritionally desirable omega-3 fatty acids in milk and meat, and conjugated linoleic acid (CLA), carotenoids and vitamin E in milk;

- Increase levels of nutritionally undesirable saturated fatty acids (e.g., myristic and palmitic acid) in meat [222,241-251].

Composition differences between organic and conventional dairy products may therefore also have contributed to the differences in disease incidence between consumer cohorts with high and low organic food consumption described in Section 3.

\subsection{Health Benefits Linked to Organic Food Consumption Need to Be Confirmed in Clinical Trials}

Nearly all dietary intervention and observational studies into the effect of organic food consumption on health markers and/or associations with health outcomes only started around 15 years ago, and most have reported their results only very recently [169,207-215]. Although organic food consumption was linked to positive health impacts in observational studies, one important limitation in the currently available evidence is that controlled clinical trials to confirm and provide a mechanistic understanding of the positive health impacts of organic food consumption reported in observational studies, have not yet been carried out [169]. As a result, there is still controversy about whether and to what extent organic food consumption has health benefits [168,169], and nutritional advice currently focuses primarily on promoting the increased consumption of fruit, vegetables and wholegrain cereal products $[163,164]$.

However, this paradigm may change, if results showing that organic food consumption is associated with a reduction in obesity, cancer and metabolic syndrome are confirmed. Given the high incidence and cost associated with the treatment of these diseases, this would also further increase the likelihood of additional government support for an expansion of organic farming.

The mounting evidence that (i) conventional fruit, vegetable and whole-grain consumption substantially increases pesticide exposure and (ii) consumption of fruit and vegetables with high pesticide loads may have negative effects on reproductive health and reduce the positive effects of fruit and vegetables, with respect to coronary heart disease, may also contribute to changes in nutritional advice, regarding the importance of organic food consumption.

It is interesting to note that some fertility clinics already advise organic food consumption as a precautionary measure to avoid exposure to pesticides [252], and that positive associations between organic food consumption and a higher sperm count and density were first reported in 1996 in the Lancet [253], but largely ignored.

\subsection{Support Required to Increase the Availability and Affordability of Organic Foods}

Demand for organic food is driven by consumer perceptions that organic farming is more sustainable, and delivers environmental, biodiversity, and food quality and safety benefits [1-3]. However, the higher cost of organic food has been shown to be the main barrier for further increases in demand for organic food [254].

According to a recent FAO report, the price difference between organic and conventional foods is due to a range of reasons, including: (i) organic food supply being more limited than demand; (ii) higher production and labor costs; (iii) additional costs of segregating organic and conventional produce during processing, storage and retailing; (iv) less efficient marketing and distribution chains [255]. The report also describes that a range of costs associated with conventional food production are not captured in the price of conventional foods, including (i) government expenditure to mitigate negative environmental impacts of intensive farming, and (ii) medical expenses associated with the inappropriate handling of pesticides by farmers [255]. 
In order to make organic food more widely available and affordable to consumers, a range of support measures have been proposed by the IFOAM Organics Europe. These include: (i) increasing access to support form agri-environment schemes; (ii) implementing existing policy frameworks for investment, procurement and promotion of organic food; (iii) improving the availability and access to advice, training and innovations [256].

Moreover, the European Union has recently published its action plan for the development of organic production which includes a range of support measures to boost both the production and consumption of organic products, and aims to reach $25 \%$ of agricultural land under organic farming by 2030 [257].

The FAO predicts that the price differential between organic and conventional foods is likely to decrease with increasing demand, because "technological innovations and economies of scale should reduce costs of production, processing, distribution and marketing of organic produce [255]. This view is supported by recent reports that conventional food prices have increased more rapidly than those of organic foods in the US, where consumption of organic food has increased rapidly over the last 10 years, although there is limited government support for the organic farming sector [258].

Author Contributions: Conceptualization, L.R., M.B. and C.L.; methodology, C.L.; validation, L.R., M.B., C.J.S. and C.L.; formal analysis, L.R., M.B.; investigation, L.R., M.B., J.W., T.N.A., K.A., J.J.B., C.J.B., B.S.D., T.F., J.D.G., M.G. (Mehmet Gür), E.I., C.L.K., R.K., S.S.K., J.K., J.M., B.N.M., B.S.N., O.B.O., A.K.O., J.O.O., L.P., N.R., S.A.W., L.X., Y.P., E.C., H.D., A.M., E.S., G.H., H.H.H.A.K., A.W. (Adam Willson), M.T., P.D., D.Ś.-T., N.V., A.W. (Anthony Watson), C.J.S., P.K.J., P.O.I., C.L.; resources, C.L.; data curation, L.R. and C.L.; writing —original draft preparation, L.R., M.B., C.L.; writingreview and editing, L.R., M.B., J.W., T.N.A., K.A., J.J.B., C.J.B., B.S.D., T.F., J.D.G., M.G. (Mehmet Gür), E.I., C.L.K., R.K., S.S.K., J.K., J.M., B.N.M., B.S.N., O.B.O., A.K.O., J.O.O., L.P., N.R., S.A.W., L.X., Y.P., E.C., H.D., A.M., E.S., G.H., H.H.H.A.K., A.W. (Adam Willson), M.T., P.D., D.Ś.-T., N.V., A.W. (Anthony Watson), C.J.S., M.G. (Mark Goltz), P.K.J., P.O.I., C.L.; visualization, L.R., P.K.J., C.L.; supervision, L.R., M.B., E.C., H.D., A.M., N.V., P.K.J., C.J.S., C.L.; project administration, C.L. All authors have read and agreed to the published version of the manuscript.

Funding: This research received no external funding.

Institutional Review Board Statement: Not applicable.

Informed Consent Statement: Not applicable.

Data Availability Statement: Data will be made available upon reasonable request by authors Carlo Leifert and Leonidas Rempelos.

Acknowledgments: The authors gratefully acknowledge the support from Jenny Gilroy for the organization of the NEFG 2017 field course and workshop in Crete.

Conflicts of Interest: The authors declare no conflict of interest.

\section{References}

1. Willer, H.; Schlatter, B.; Trávníček, J.; Kemper, L.; Julia Lernoud, J. The World of Organic Agriculture 2020; FiBL/IFOAM: Frick, Switzerland, 2020; Available online: www.fibl.org/fileadmin/documents/shop/5011-organic-world-2020.pdf (accessed on 23 February 2021).

2. Joshi, Y.; Rahman, Z. Factors Affecting Green Purchase Behaviour and Future Research Directions. Int. Strateg. Manag. Rev. 2015, 3, 128-143. [CrossRef]

3. Stolz, H.; Stolze, M.; Hamm, U.; Janssen, M.; Ruto, E. Consumer attitudes towards organic versus conventional food with specific quality attributes. NJAS-Wagen. J. Life Sci. 2011, 58, 67-72. [CrossRef]

4. European Union. Commission Implementation Regulation (EU) 2016/673 of 29 April 2016 Amending Regulation (EC) No 889/2008 Laying Down Detailed Rules for the Implementation of Council Regulation (EC) No 834/2007 on Organic Production and Labelling of Organic Products with Regard to Organic Production, Labelling and Control. 2016. Available online: https: / / eur-lex.europa.eu/eli/reg_impl/2016/673/oj (accessed on 23 February 2021).

5. Baker, B.P.; Benbrook, C.M.; Groth, E.; Benbrook, K. Pesticide residues in conventional, integrated pest management (IPM)-grown and organic foods: Insights from three US data sets. Food Addit. Contam. 2002, 19, 427-446. [CrossRef] [PubMed]

6. Hansen, A.L. The Organic Farming Manual: A Comprehensive Guide to Starting and Running a Certified Organic Farm; Storey Publishing: North Adams, MA, USA, 2010. 
7. Murphy, K.M.; Campbell, K.G.; Lyon, S.R.; Jones, S.S. Evidence of varietal adaptation to organic farming systems. Field Crop. Res. 2007, 102, 172-177. [CrossRef]

8. Speiser, B.; Tamm, L.; Amsler, T.; Lambion, J.; Bertrand, C.; Hermansen, A.; Ruissen, M.A.; Haaland, P.; Zarb, J.; Santos, J.; et al. Field tests of blight control methods for organic farming: Tolerant varieties and copper fungicides. Biol. Agric. Hortic. 2006, 23, 393-412. [CrossRef]

9. Wolfe, M.S.; Baresel, J.P.; Desclaux, D.; Goldringer, I.; Hoad, S. Developments in breeding cereals for organic agriculture. Euphytica 2008, 163, 323. [CrossRef]

10. Lammerts van Bueren, E.T.; Jones, S.S.; Tamm, L.; Murphy, K.M.; Myers, J.R.; Leifert, C.; Messmer, M.M. The need to breed crop varieties suitable for organic farming, using wheat, tomato and broccoli as examples: A review. NJAS-Wagen. J. Life Sci. 2010, 58, 193-205. [CrossRef]

11. Crespo-Herrera, L.A.; Ortiz, R. Plant breeding for organic agriculture: Something new? Agric. Food Secur. 2015, 4, 1-7. [CrossRef]

12. Hasanaliyeva, G.; Chatzidimitrou, E.; Wang, J.; Baranski, M.; Volakakis, N.; Seal, C.; Rosa, E.A.S.; Iversen, P.O.; Vigar, V.; Barkla, B.; et al. Effects of Production Region, Production Systems and Grape Type/Variety on Nutritional Quality Parameters of Table Grapes; Results from a UK Retail Survey. Foods 2020, 16, 1874. [CrossRef] [PubMed]

13. Rempelos, L.; Almuayrifi, M.S.B.; Barański, M.; Tetard-Jones, C.; Barkla, B.; Cakmak, I.; Ozturk, L.; Cooper, J.; Volakakis, N.; Hall, G.; et al. The effect of agronomic factors on crop health and performance of winter wheat varieties bred for the conventional and the low input farming sector. Field Crop. Res. 2020, 254, 107822. Available online: https:/ / authors.elsevier.com/sd/article/S037 8429019315990 (accessed on 4 November 2021). [CrossRef]

14. Seufert, V.; Ramankutty, N.; Foley, J.A. Comparing the yields in organic and conventional agriculture. Nature 2012, 485, 229-234. [CrossRef]

15. De Ponti, T.; Rijk, B.; van Ittersum, M.K. The crop yield gap between organic and conventional agriculture. Agric. Syst. 2012, 108, 1-9. [CrossRef]

16. Wilbois, K.-P.; Schmidt, J.E. Reframing the Debate Surrounding the Yield Gap between Organic and Conventional Farming. Agronomy 2019, 9, 82. [CrossRef]

17. Schram, M.; de Haan, J.J.; Kroonen, M.; Verstegen, H.; Van der Putten, W.H. Crop yield gap and stability in organic and conventional farming systems. Agric. Ecosyst. Environ. 2018, 256, 123-130. [CrossRef]

18. Ponisio, L.C.; M'Gonigle, L.K.; Mace, K.C.; Palomino, J.; de Valpine, P.; Kremen, C. Diversification practices reduce organic to conventional yield gap. Proc. R. Soc. B 2015, 282, 20141396. [CrossRef] [PubMed]

19. Hasanaliyeva, G.; Chatzidimitrou, E.; Wang, J.; Baranski, M.; Volakakis, N.; Pakos, P.; Seal, C.; Rosa, E.A.S.; Markellou, E.; Iversen, P.O.; et al. Effect of organic and conventional Production Methods on Fruit Yield and Nutritional Quality Parameters in Table Grapes and Wine made from three traditional Cretan Grape Varieties; Results from a Farm Survey. Foods 2021, 10, 476. [CrossRef]

20. Palmer, M.W.; Cooper, J.; Tétard-Jones, C.; Średnicka-Tober, D.; Baranski, M.; Eyre, M.; Shotton, P.; Volakakis, N.; Cakmak, I.; Ozturk, L.; et al. The influence of organic and conventional fertilisation and crop protection practices, preceding crop, harvest year and weather conditions on yield and quality of potato (Solanum tuberosum) in a long-term management trial. Eur. J. Agron. 2013, 49, 83-92. [CrossRef]

21. Tétard-Jones, C.; Edwards, M.G.; Rempelos, L.; Gatehouse, A.M.R.; Eyre, M.; Wilcockson, S.J.; Leifert, C. Effects of previous crop management, fertilization regime and water supply on potato tuber proteome and yield. Agronomy 2013, 3, 59-85. [CrossRef]

22. Roser, M.; Ritchie, H. Our World in Data-Fertilizers. Available online: https:/ / ourworldindata.org/fertilizers (accessed on 23 February 2021).

23. FAO. Statistics on Pesticide Use in Agriculture. Available online: http://www.fao.org/economic/ess/environment/data/ pesticides-use/en/ (accessed on 23 February 2021).

24. Leifert, C.; Rembiałkowska, E.; Nielson, J.H.; Cooper, J.M.; Butler, G.; Lueck, L. Effects of organic and 'low input' production methods on food quality and safety. In Improving Sustainability in Organic and Low Input Food Production Systems; Niggli, U., Leifert, C., Alföldi, T., Lueck, L., Willer, H., Eds.; FiBL: Frick, Switzerland, 2007; pp. 15-96.

25. Blake, F. Organic Farming and Growing; The Crowood Press: Marlborough, UK, 2005.

26. Nandwani, D. Organic Farming for Sustainable Agriculture; Springer International Publishing: Basel, Switzerland, 2016.

27. Haghighi, R.S.; Critchley, N.; Leifert, C.; Eyre, M.; Cooper, J. Individual and interactive effects of crop type and management on weed and seed bank composition in an organic rotation. Int. J. Plant Prod. 2013, 7, 243-268.

28. Eyre, M.D.; Critchley, C.N.R.; Leifert, C.; Wilcockson, S.J. Crop sequence, crop protection and fertility management effects on weed cover in an organic/conventional farm management trial. Eur. J. Agron. 2011, 59, 4715-4724. [CrossRef]

29. Hill, O. How grazing livestock can beat blackgrass. Farmers Wkly. 2015. Available online: www.fwi.co.uk/arable/grazinglivestock-can-beat-blackgrass (accessed on 24 February 2021).

30. Råberg, T.; Carlsson, G.; Jensen, E.S. Nitrogen balance in a stockless organic cropping system with different strategies for internal $\mathrm{N}$ cycling via residual biomass. Nutr. Cycl. 2018, 112, 165-178. [CrossRef]

31. Barbieri, P.; Pellerin, S.; Nesme, T. Comparing crop rotations between organic and conventional farming. Sci. Rep. 2017, 7, 13761. [CrossRef]

32. Sandra Wayman, S.; Kissing Kucek, L.; Mirsky, S.B.; Ackroyd, V.; Cordeau, S.; Ryan, M.R. Organic and conventional farmers differ in their perspectives on cover crop use and breeding. Renew. Agric. Food Syst. 2016, 32, 376-385. [CrossRef] 
33. Rempelos, L.; Almuayrifi, A.M.; Baranski, M.; Tetard-Jones, C.; Eyre, M.; Shotton, P.; Cakmak, I.; Ozturk, L.; Cooper, J.; Volakakis, $\mathrm{N}$; ; et al. Effects of agronomic management and climate on leaf phenolic profiles, disease severity and grain yield in organic and conventional wheat production systems. J. Agric. Food Chem. 2018, 66, 10369-10379. [CrossRef]

34. Keiser, A.; Haeberli, M.; Stamp, P. Quality deficiencies on potato (Solanum tuberosum L.) tubers caused by Rhizoctonia solani, wireworms (Agriotes ssp.) and slugs (Deroceras reticulatum, Arion hortensis) in different farming systems. Field Crop. Res. 2012, 128, 147-155. [CrossRef]

35. Benaragama, D.; Leeson, J.L.; Shirtliffe, S.J. Understanding the long term weed community dynamics in organic and conventional crop rotations using the principal response curve method. Weed Sci. 2018, 67, 195-204. [CrossRef]

36. Robson, M.C.; Fowler, S.M.; Lampkin, N.H.; Leifert, C.; Leitch, M.; Robinson, D.; Watson, C.A.; Litterick, A.M. The agronomic and economic potential of break crops for ley/arable rotations in temperate organic agriculture. Adv. Agron. 2002, 77, 370-427.

37. Paulsen, H.M.; Weißmann, F. Relevance of mycotoxins to product quality and animal health in organic farming. In Proceedings of the 14th IFOAM Organic World Congress, Victoria, Canada, 21-24 August 2002; Available online: https:/ / orgprints.org/2023 /1/2023-paulsen-weissmann-2002-14th-ifoam-ca-p212.pdf (accessed on 24 February 2021).

38. Bernhoft, A.; Clasen, P.-E.; Kristoffersen, A.B.; Torp, M. Less Fusarium infestation and mycotoxin contamination in organic than in conventional cereals. Food Addit. Contam. 2010, 27, 842-852. [CrossRef]

39. Wang, J.; Hasanalieva, G.; Wood, L.; Markellou, E.; Iversen, P.O.; Bernhoft, A.; Seal, C.; Baranski, M.; Vigar, V.; Ernst, L.; et al. Effect of wheat species (Triticum aestivum vs. T. spelta), farming system (organic vs. conventional) and flour type (wholegrain vs. white) on composition of wheat flour; results of a retail survey in the UK and Germany-1. mycotoxin content. Food Chem. 2020, 327, 127011. [CrossRef]

40. Wang, J. Effect of Organic and Conventional Agronomic Practices and Variety Choice on Nutritional Quality, the Contents of Undesirable Compounds and Yield of Cereals. Ph.D. Thesis, Newcastle University, Newcastle Upon Tyne, UK, 2019.

41. Thavarajah, D.; Siva, N.; Johnson, N.; McGee, R.; Thavarajah, P. Effect of cover crops on the yield and nutrient concentration of organic kale (Brassica oleracea L. var. acephala). Sci. Rep. 2019, 9, 10374. [CrossRef]

42. Tilman, D.; Cassman, K.G.; Matson, P.A.; Naylor, R.; Polasky, S. Agricultural sustainability and intensive production practices. Nature 2002, 418, 671-677. [CrossRef] [PubMed]

43. Cordell, D.; Drangert, J.-O.; White, S. The story of phosphorus: Global food security and food for thought. Glob. Environ. Chang. 2009, 19, 292-305. [CrossRef]

44. Chowdhury, R.B.; Moore, G.A.; Weatherley, A.J.; Arora, M. Key sustainability challenges for the global phosphorus resource, their implications for global food security, and options for mitigation. J. Clean. Prod. 2017, 140, 945-963. [CrossRef]

45. Cordell, D.; Jackson, M.; White, S. Phosphorus flows through the Australian food system: Identifying intervention points as a roadmap to phosphorus security. Environ. Sci. Policy 2013, 29, 87-102. [CrossRef]

46. Farm Carbon Toolkit. Fertiliser Production. 2021. Available online: www.farmcarbontoolkit.org.uk/toolkit/fertiliser-production (accessed on 25 February 2021).

47. Niggli, U. History and concepts of food quality and safety in organic food production and processing. In Handbook of Organic Food Safety and Quality; Cooper, J., Niggli, U., Leifert, C., Eds.; Woodhead Publishing Ltd.: Cambridge, UK, 2007 ; pp. 9-24.

48. Alburquerque, J.A.; de la Fuente, C.; Campoy, M.; Carrasco, L.; Nájera, I.; Baixauli, C.; Caravaca, F.; Roldán, A.; Cegarra, J.; Bernal, M.P. Agricultural use of digestate for horticultural crop production and improvement of soil properties. Eur. J. Agron. 2012, 119-128. [CrossRef]

49. Gerlach, F.; Grieb, B.; Zerger, U. Sustainable Biogas Production; A Handbook for Organic Farmers; FiBL Projecte GmbH: Frankfurt, Germany, 2013; Available online: https:/ / aa.ecn.cz/img_upload/8d8825f1d3b154e160e6e5c97cf9b8b3/sustaingas_handbook_en. pdf (accessed on 4 December 2021).

50. Magistrali, A.; Vavera, R.; Janovska, D.; Rempelos, L.; Cakmak, I.; Leifert, C.; Grausgruber, H.; Butler, G.; Wilkinson, A.; Bilsborrow, P. Evaluating the effect of agronomic management practices on the performance of differing spelt (Triticum spelta) cultivars in contrasting environments. Field Crop. Res. 2020, 255, 107869. [CrossRef]

51. Margaritopoulou, T.; Toufexi, E.; Kizis, D.; Balayiannis, G.; Anagnostopoulos, C.; Theocharis, A.; Rempelos, L.; Troyanos, Y.; Leifert, C.; Markellou, E. Reynoutria sachalinensis extract elicits SA-dependent defence responses in courgette genotypes against powdery mildew caused by Podosphaera xanthii. Sci. Rep. 2020, 10, 3354. [CrossRef]

52. Sander, J.F.; Heitefuss, R. Susceptibility to Erysiphe graminis f. sp. tritici and phenolic acid content of wheat as influenced by different levels of nitrogen fertilization. J. Phytopathol. 1988, 146, 495-507. [CrossRef]

53. Leser, C.; Treutter, D. Effects of nitrogen supply on growth, contents of phenolic compounds and pathogen (scab) resistance of apple trees. Physiol. Plant. 2004, 123, 49-56. [CrossRef]

54. Sun, Y.; Guo, J.; Li, Y.; Luo, G.; Li, L.; Yuan, H.; Mur, L.A.J.; Guo, S. Negative effects of the simulated nitrogen deposition plant phenolic metabolism: A meta-analysis. Sci. Total Environ. 2020, 719, 137442. [CrossRef]

55. Lin, D.; Xiao, M.; Zhao, J.; Li, Z.; Xing, B.; Li, X.; Kong, M.; Li, L.; Zhang, Q.; Liu, Y.; et al. An Overview of Plant Phenolic Compounds and Their Importance in Human Nutrition and Management of Type 2 Diabetes. Molecules 2016, 21, 1374. [CrossRef]

56. Brandt, K.; Leifert, C.; Sanderson, R.; Seal, C.J. Agroecosystem management and nutritional quality of plant foods: The case of organic fruits and vegetables. CRC Crit. Rev. Plant Sci. 2011, 30, 177-197. [CrossRef] 
57. Baranski, M.; Średnicka-Tober, D.; Volakakis, N.; Seal, C.; Sanderson, R.; Stewart, G.B.; Benbrook, C.; Biavati, B.; Markellou, E.; Giotis, H.; et al. Higher antioxidant and lower cadmium concentrations and lower incidence of pesticide residues in organically grown crops: A systematic literature review and meta-analysis. Br. J. Nutr. 2014, 112, 794-811. [CrossRef]

58. European Commission. Final Report Summary-QUALITYLOWINPUTFOOD (Improving Quality and Safety and Reduction of Cost in the European Organic and 'Low Input' Supply Chains. 2009. Available online: https://cordis.europa.eu/project/id/5063 58/reporting (accessed on 24 February 2021).

59. Wang, J.; Chatzidimitriou, E.; Wood, L.; Hasanalieva, G.; Markellou, E.; Iversen, P.O.; Seal, C.; Baranski, M.; Vigar, V.; Ernst, L.; et al. Effect of wheat species (Triticum aestivum vs T. spelta), farming system (organic vs conventional) and flour type (wholegrain vs white) on composition of wheat flour-Results of a retail survey in the UK and Germany-2. Antioxidant activity, and phenolic and mineral content. Food Chem. X 2020, 6, 100091. [CrossRef]

60. Hasanaliyeva, G. Effect of Organic Production Methods on Antioxidant Activity and Concentrations in Grapes, Grape Juice and Wine; Results from Meta-Analyses, and Farm and Retail Surveys. Ph.D. Thesis, Newcastle University, Newcastle Upon Tyne, UK, 2017.

61. Gosling, P.; Hodge, A.; Goodlass, G.; Bending, G.D. Arbuscular mycorrhizal fungi and organic farming. Agric. Ecosyst. Environ. 2006, 113, 17-35. [CrossRef]

62. Lee, S.-W.; Lee, E.-H.; Eom, A.-H. Effects of Organic Farming on Communities of Arbuscular Mycorrhizal Fungi. Mycobiology 2008, 36, 19-23. [CrossRef] [PubMed]

63. Säle, V.; Aguilera, P.; Laczko, E.; Mäder, P.; Berner, A.; Zihlmann, U.; van der Heijden, M.G.A.; Oehl, F. Impact of conservation tillage and organic farming on the diversity of arbuscular mycorrhizal fungi. Soil Biol. Biochem. 2015, 84, 38-52. [CrossRef]

64. Grant, C.A.; Sheppard, S.C. Fertilizer impacts on cadmium availability in agricultural soils and Crops. Hum. Ecol. Risk Assess. 2008, 14, 210-228. [CrossRef]

65. Cooper, J.; Sanderson, R.; Cakmak, I.; Ozturk, L.; Shotton, P.; Carmichael, A.; Sadrabadi Haghighi, R.; Tetard-Jones, C.; Volakakis, N.; Eyre, M.; et al. Effect of organic and conventional crop rotation, fertilization and crop protection practices on metal contents in wheat (Triticum aestivum). J. Agric. Food Chem. 2011, 59, 4715-4724. [CrossRef] [PubMed]

66. Dharma-wardana, M.W.C. Fertilizer usage and cadmium in soils, crops and food. Environ. Geochem. Health 2018, 40, 2739-2759. [CrossRef]

67. Abou-Shanab, R.A.I.; Wongphatcharachai, M.; Sheaffer, C.C.; Sadowsky, M.J. Response of dry bean (Phaseolus vulgaris L.) to inoculation with indigenous and commercial Rhizobium strains under organic farming systems in Minnesota. Symbiosis 2019, 78, 125-134. [CrossRef]

68. Ardakani, M.R.; Pietsch, G.; Moghaddam, A.; Raza, A.; Friedel, J.K. Response of Root Properties to Tripartite Symbiosis between Lucerne (Medicago sativa L.), Rhizobia and Mycorrhiza. Am. J. Agric. Biol. Sci. 2009, 4, $266-277$.

69. Wilkinson, A. Improving the Agronomic Management and Utilization of Breadmaking Wheat. Ph.D. Thesis, Newcastle University, Newcastle upon Tyne, UK, 2020.

70. Aryal, U.K.; Shah, S.K.; Xu, H.L.; Fujita, M. Growth, Nodulation and Mycorrhizal Colonization in Bean Plants Improved by Rhizobial Inoculation with Organic and Chemical Fertilization. J. Sustain. Agric. 2007, 29, 71-83. [CrossRef]

71. Faye, A.; Stewart, Z.P.; Ndung'u-Magiroi, K.; Diouf, M.; Ndoye, I.; Diop, T.; Dalpé, Y.; Prasad, P.V.V.; Lesueur, D. Testing of Commercial Inoculants to Enhance P Uptake and Grain Yield of Promiscuous Soybean in Kenya. Sustainability 2020, $12,3803$. [CrossRef]

72. Mukherjee, A.; Omondi, E.C.; Hepperly, P.R.; Seidel, R.; Heller, W.P. Impacts of Organic and Conventional Management on the Nutritional Level of Vegetables. Sustainability 2020, 12, 8965. [CrossRef]

73. Gianinazzi, S.; Schüepp, H.; Barea, J.M.; Haselwandter, K. Mycorrhizal Technology in Agriculture; From Genes to Bioproducts; Springer: Basel, Switzerland, 2002.

74. Oliveira, R.S.; Rocha, I.; Ma, Y.; Vosátka, M.; Freitas, H. Seed coating with arbuscular mycorrhizal fungi as an ecotechnologicalapproach for sustainable agricultural production of common wheat (Triticum aestivum L.). J. Toxicol. Environ. Health Part A 2016, 79, 329-337. [CrossRef] [PubMed]

75. Berruti, A.; Lumini, E.; Balestrini, R.; Bianciotto, V. Arbuscular Mycorrhizal Fungi as Natural Biofertilizers: Let's Benefit from Past Successes. Front. Microbiol. 2016, 6, 1559. [CrossRef]

76. Elliott, A.J.; Daniell, T.J.; Cameron, D.D.; Field, K.J. A commercial arbuscular mycorrhizal inoculum increases root colonization across wheat cultivars but does not increase assimilation of mycorrhiza-acquired nutrients. Plants People Planet 2020, 3, 588-599. [CrossRef]

77. Reganold, J.P.; Elliott, L.F.; Unger, Y.L. Long-term effects of organic and conventional farming on soil erosion. Nature 1987, 330, 370-372. [CrossRef]

78. Mäder, P.; Fliessbach, A.; Dubois, D.; Gunst, L.; Fried, P.; Niggli, U. Soil fertility and biodiversity in organic farming. Science 2002, 296, 1694-1697. [CrossRef]

79. Gattinger, A.; Muller, A.; Haeni, M.; Skinner, C.; Fliessbach, A.; Buchmann, N.; Mader, P.; Stolze, M.; Smith, P.; Scialabba Nel, H.; et al. Enhanced top soil carbon stocks under organic farming. Proc. Natl. Acad. Sci. USA 2012, 109, 18226-18231. [CrossRef] [PubMed] 
80. Eyre, M.D.; Sanderson, R.A.; Shotton, P.N.; Leifert, C. Investigating the effects of crop type, fertility management and crop protection on the activity of beneficial invertebrates in an extensive farm management comparison trial. Ann. Appl. Biol. 2009, 155, 267-276. [CrossRef]

81. Hadar, Y.; Papadopoulou, K.K. Suppressive composts: Microbial ecology links between abiotic environments and healthy plants. Ann. Rev. Phytopathol. 2012, 50, 133-153. [CrossRef] [PubMed]

82. Yogev, A.; Laor, Y.; Katan, J.; Hadar, Y.; Cohen, R.; Medina, S.; Raviv, M. Does organic farming increase soil suppression against Fusarium wilt of melon? Org. Agric. 2011, 1, 203-216. [CrossRef]

83. Giotis, C.; Markelou, E.; Theodoropoulou, A.; Toufexi, E.; Hodson, R.; Shotton, P.; Shiel, R.; Cooper, J.; Leifert, C. Effect of soil amendments and biological control agents (BCAs) on soil-borne root diseases caused by Pyrenochaeta lycopersici and Verticillium alboatrum in organic greenhouse tomato production systems. Eur. J. Plant Pathol. 2009, 123, 387-400. [CrossRef]

84. Giotis, C.; Theodoropoulou, A.; Cooper, J.; Hodgson, R.; Shotton, P.; Shiel, R.; Eyre, M.; Wilcockson, S.; Markellou, E.; LiopaTsakalidis, A.; et al. Effect of variety choice, resistant rootstocks and chitin soil amendments on soil-borne diseases in soil-based, protected tomato production systems. Eur. J. Plant Pathol. 2012, 134, 605-617. [CrossRef]

85. Tamm, L.; Thürig, B.; Bruns, C.; Fuchs, J.G.; Köpke, U.; Leifert, C.; Mahlberg, N.; Nietlispach, B.; Laustela, M.; Schmidt, C.; et al . Soil type, management history, and soil amendments influence the development of soilborne (Rhizoctonia solani, Pythium ultimum) and airborne (Phytophthora infestans, Hyaloperonospora parasitica) diseases. Eur. J. Plant Pathol. 2010, 127, 465-481. [CrossRef]

86. Willson, A.; Goltz, M.; Markellou, E.; Volakakis, N.; Leifert, C. Integrating the use of resistant rootstocks/cultivars, suppressive composts and elicitors to improve yields and quality in protected organic cultivation systems. Acta Hortic. 2020, 1268, 155-164. [CrossRef]

87. Bonanomi, G.; Antignani, V.; Capodilupo, M.; Scala, F. Identifying the characteristics of organic soil amendments that suppress soilborne plant diseases. Soil Biol. Biochem. 2010, 42, 136-144. [CrossRef]

88. Litterick, A.M.; Harrier, L.; Wallace, P.; Watson, C.A.; Wood, M. The role of uncomposted materials, composts, manures, and compost extracts in reducing pest and disease incidence and severity in sustainable temperate agricultural and horticultural production-A review. CRC Crit. Rev. Plant Sci. 2004, 23, 453-479. [CrossRef]

89. Noble, R.; Coventry, E. Suppression of soil-borne plant diseases with composts: A review. Biocontrol Sci. Technol. 2005, 15, 3-20. [CrossRef]

90. Brennan, R.J.B.; Glaze-Corcoran, S.; Wick, R.; Hashemi, M. Biofumigation: An alternative strategy for the control of plant parasitic nematodes. J. Integr. Agric. 2020, 19, 1680-1690. [CrossRef]

91. Ren, H.; Endo, H.; Hayashi, T. Antioxidative and antimutagenic activities and polyphenol content of pesticide-free and organically cultivated green vegetables using water-soluble chitosan as a soil modifier and leaf surface spray. J. Sci. Food Agric. 2001, 81, 1426-1432. [CrossRef]

92. Ghasemi Pirbalouti, A.; Malekpoor, F.; Salimi, A.; Golparvar, A. Exogenous application of chitosan on biochemical and physiological characteristics, phenolic content and antioxidant activity of two species of basil (Ocimum ciliatum and Ocimum basilicum) under reduced irrigation. Sci. Hortic. 2017, 217, 114-122. [CrossRef]

93. Rahman, M.; Mukta, J.A.; Sabir, A.A.; Gupta, D.R.; Mohi-Ud-Din, M.; Hasanuzzaman, M.; Miah, M.G.; Rahman, M.; Islam, M.T. Chitosan biopolymer promotes yield and stimulates accumulation of antioxidants in strawberry fruit. PLoS ONE 2018, 13, 0203769. [CrossRef]

94. Ben-Issa, R.; Gomez, L.; Gautier, H. Companion Plants for Aphid Pest Management. Insects 2017, 8, 112. [CrossRef]

95. Eyre, M.D.; Leifert, C. Crop and field boundry influences on the activity of a wide range of beneficial invertebrate groups on a split conventional/organic farm in northern England. Bull. Entomol. Res. 2011, 101, 135-144. [CrossRef] [PubMed]

96. Eyre, M.D.; Labanowska-Bury, D.; White, R.; Leifert, C. Relationship between beneficial invertebrates, field margin vegetation, and thrip damage in organic leek fields in eastern England. Org. Agric. 2011, 1, 45-54. [CrossRef]

97. Eyre, M.D.; Luff, M.L.; Leifert, C. Crop, field boundary, productivity and disturbance influences on ground beetles (Coleoptera, Carabidae) in the agroecosystem. Agric. Ecosyst. Environ. 2013, 165, 60-67. [CrossRef]

98. MacLeod, A.; Wratten, S.D.; Sotherton, N.W.; Thomas, M.B. 'Beetle banks' as refuges for beneficial arthropods in farmland: Long-term changes in predator communities and habitat. Agric. For. Entomol. 2004, 6, 147-154. [CrossRef]

99. Bengtsson, J.; Ahnström, J.; Weibull, A.-C. The Effects of Organic Agriculture on Biodiversity and Abundance: A Meta-Analysis. J. Appl. Ecol. 2005, 42, 261-269. [CrossRef]

100. Gabriel, D.; Tscharntke, T. Insect pollinated plants benefit from organic farming. Agric. Ecosyst. Environ. 2007, 118, 43-48. [CrossRef]

101. Muneret, L.; Auriol, A.; Bonnard, O.; Richart-Cervera, S.; Thiéry, D.; Rusch, A. Organic farming expansion drives natural enemy abundance but not diversity in vineyard-dominated landscapes. Ecol. Evol. 2019, 9, 13532-13542. [CrossRef] [PubMed]

102. Birkhofer, K.; Arvidsson, F.; Ehlers, D.; Mader, V.L.; Bengtsson, J.; Smith, H.G. Organic farming affects the biological control of hemipteran pests and yields in spring barley independent of landscape complexity. Landsc. Ecol. 2016, 31, 567-579. [CrossRef]

103. Kasselaki, A.M.; Malathrakis, N.E.; Goumas, D.E.; Leifert, C. Effect of alternative treatments on seed borne Didymella lycopersici in tomato. J. Appl. Microbiol. 2008, 105, 36-41. [CrossRef]

104. Kasselaki, A.-M.; Goumas, D.; Tamm, L.; Fuchs, J.; Cooper, C.; Leifert, C. Effect of alternative strategies for the disinfection of tomato seed infected with bacterial canker (Clavibacter michiganensis subsp. michiganensis). NJAS-Wagen. J. Life Sci. 2011, 58, 145-147. [CrossRef] 
105. Giotis, C.; Markellou, E.; Theodoropoulou, A.; Kostoulas, G.; Wilcockson, S.; Leifert, C. The effects of different biological control agents (BCAs) and plant defence elicitors on cucumber powdery mildew (Podosphera xanthii). Org. Agric. 2012, 2, 89-101. [CrossRef]

106. Dafermos, N.G.; Kasselaki, A.M.; Goumas, D.E.; Eyre, M.D.; Spandidakis, K.; Leifert, C. Integration of Elicitors and Less Susceptible Hybrids for the Control of Powdery Mildew in Organic Tomato Crops. Plant Dis. 2012, 96, 1506-1512. [CrossRef]

107. Margaritopoulou, T.; Kizis, D.; Kotopoulis, D.; Papadakis, I.E.; Anagnostopoulos, C.; Baira, E.; Termentzi, A.; VichouLeifert, C.; Markellou, E. Enriched HeK4me3 marks at Pm-0 resistance-related genes prime courgette against Podosphaera xanthii. Plant Physiol. 2021, kiab453. [CrossRef] [PubMed]

108. Barratt, B.I.P.; Moran, V.C.; Bigler, F.; van Lenteren, J.C. The status of biological control and recommendations for improving uptake for the future. Biocontrol 2018, 63, 155-167. [CrossRef]

109. Thambugala, K.M.; Daranagama, D.A.; Phillips, A.J.L.; Kannangara, S.D.; Itthayakor, P. Fungi vs. Fungi in Biocontrol: An Overview of Fungal Antagonists Applied Against Fungal Plant Pathogens. Front. Cell. Infect. Microbiol. 2020, $10,604923$. [CrossRef] [PubMed]

110. Köhl, J.; Kolnaar, R.; Ravensberg, W.J. Mode of Action of Microbial Biological Control Agents Against Plant Diseases: Relevance Beyond Efficacy. Front. Plant Sci. 2019, 10, 00845. [CrossRef]

111. Pesticide Action Network. Is Organic Better? 2017. Available online: www.pan-uk.org/organic/ (accessed on 1 June 2021).

112. Kuesel, R.; Scott Hicks, D.; Archer, K.; Sciligo, A.; Bessin, R.; Gonthier, D. Effects of Fine-Mesh Exclusion Netting on Pests of Blackberry. Insects 2019, 10, 249. [CrossRef]

113. Gogo, E.O.; Saidi, M.; Itulya, F.M.; Martin, T.; Mathieu Ngouajio, M. Eco-Friendly Nets and Floating Row Covers Reduce Pest Infestation and Improve Tomato (Solanum lycopersicum L.) Yields for Smallholder Farmers in Kenya. Agronomy 2014, 4, 1-12. [CrossRef]

114. Mahmood, A.; Hu, Y.; Tanny, J.; Asante, E.A. Effects of shading and insect-proof screens on crop microclimate and production: A review of recent advances. Sci. Hortic. 2018, 241, 241-251. [CrossRef]

115. Savoldelli, S.; Trematerra, P. Mass-trapping, mating-disruption and attracticide methods for managing stored-product insects: Success stories and research needs. Stewart Postharvest Rev. 2011, 7, 1-8. [CrossRef]

116. Volakakis, N.; Kabourakis, E.; Leifert, C. Conventional and organic cultivation and their effect on the functional composition of olive oil. In Olives and Olive Oil as Functional Foods; Kiritsakis, A., Shahidi, F., Eds.; Wiley: Oxford, UK, 2017; pp. 35-44.

117. Volakakis, N. Development of Strategies to Improve the Quality and Productivity of Organic and 'Low Input' Olive Production Systems in Semi-Arid Mediterranean Regions. Ph.D. Thesis, Newcastle University, Newcastle Upon Tyne, UK, 2010.

118. Nikolouli, K.; Sassù, F.; Mouton, L.; Stauffer, C.; Bourtzis, K. Combining sterile and incompatible insect techniques for the population suppression of Drosophila suzukii. J. Pest Sci. 2020, 93, 647-661. [CrossRef]

119. Baker, T.C.; Zhu, J.J.; Millar, J.G. Delivering on the promise of pheromones. J. Chem. Ecol. 2016, 42, 553-556. [CrossRef]

120. Marliac, G.; Penvern, S.; Barbier, J.M.; Lescourret, F.; Capowiez, Y. Impact of crop protection strategies on natural enemies in organic apple production. Agron. Sustain. Dev. 2015, 35, 803-813. [CrossRef]

121. van Loenen, M.C.A.; Turbett, Y.; Mullins, C.E.; Feilden, N.E.H.; Wilson, M.J.; Leifert, C.; Seel, W. Low temperature-short duration steaming of soils kills soil-borne pathogens, nematodes and weeds. Eur. J. Plant Pathol. 2003, 109, 993-1002. [CrossRef]

122. Williams, J.S.; Cooper, R.M. The oldest fungicide and newest phytoalexin-A reappraisal of the fungitoxicity of elemental sulphur. Plant Pathol. 2004, 53, 263-279. [CrossRef]

123. Komárek, M.; Čadková, E.; Chrastný, V.; Bordas, F.; Bollinger, J.-C. Contamination of vineyard soils with fungicides: A review of environmental and toxicological aspects. Environ. Int. 2010, 36, 138-151. [CrossRef] [PubMed]

124. Ndakidemi, B.; Mtei, K.; Ndakidemi, P.A. Impacts of Synthetic and Botanical Pesticides on Beneficial Insects. Agric. Sci. 2016, 7, 364-372. [CrossRef]

125. Zanuncio, J.C.; Abreu Mourão, S.; Martínez, L.C.; Wilcken, C.F.; Ramalho, F.S.; Plata-Rueda, A.; Alvarenga Soares, M.; Serrão, J.E. Toxic effects of the neem oil (Azadirachta indica) formulation on the stink bug predator, Podisus nigrispinus (Heteroptera: Pentatomidae). Sci. Rep. 2016, 6, 30261. [CrossRef] [PubMed]

126. EFSA. Peer review of the pesticide risk assessment of the active substance spinosad. EFSA J. 2018, 16, 5252.

127. Chrustek, A.; Hołyńska-Iwan, I.; Dziembowska, I.; Bogusiewicz, J.; Wróblewski, M.; Cwynar, A.; Olszewska-Słonina, D. Current research on the safety of pyrethroids used as insecticides. Medicina 2018, 54, 61. [CrossRef]

128. EFSA. The 2018 European Union Report on Pesticide Residues in Food. EFSA J. 2020, 18, 6057. Available online: https: / / efsa.onlinelibrary.wiley.com/doi/10.2903/j.efsa.2020.6057 (accessed on 4 February 2021).

129. Markantonis, M.; van der Velde-Koerts, T.; Graven, C.; te Biesebeek, J.D.; Zeilmaker, M.; Rietveld, A.G.; Ossendorp, B.C. Assessment of occupational and dietary exposure to pesticide residues. EFSA J. 2018, 16, 16087.

130. Bjørling-Poulsen, M.; Andersen, H.R.; Grandjean, P. Potential developmental neurotoxicity of pesticides used in Europe. Environ. Health 2008, 7, 50. [CrossRef]

131. EFSA. Evaluation of the data on clothianidin, imidacloprid and thiamethoxam for the updated risk assessment to bees for seed treatments and granules in the EU. EFSA Support. Publ. 2018, 15, 1378.

132. Schug, T.T.; Janesick, A.; Blumberg, B.; Heindel, J.J. Endocrine disrupting chemicals and disease susceptibility. J. Steroid Biochem. Mol. Biol. 2011, 12, 204-215. [CrossRef] [PubMed] 
133. Costas, L.; Infante-Rivard, C.; Zock, J.P.; Van Tongeren, M.; Boffetta, P.; Cusson, A.; Robles, C.; Casabonne, D.; Benavente, Y.; Becker, N.; et al. Occupational exposure to endocrine disruptors and lymphoma risk in a multi-centric European study. Br. J. Cancer 2015, 112, 1251-1256. [CrossRef]

134. Bonde, J.P.; Meulengracht Flachs, E.; Rimborg, S.; Glaser, C.H.; Giwercman, A.; Ramlau-Hansen, C.H.; Sørig Hougaard, K.; Høyer, B.B.; Keglberg Hærvig, K.; Bondo Petersen, S.; et al. The epidemiologic evidence linking prenatal and postnatal exposure to endocrine disrupting chemicals with male reproductive disorders: A systematic review and meta-analysis. Hum. Reprod. Update 2017, 23, 104-125. [CrossRef] [PubMed]

135. Nicolopoulou-Stamati, P.; Maipas, S.; Kotampasi, C.; Stamatis, P.; Hens, L. Chemical pesticides and human health: The urgent need for a new concept in agriculture. Front Public Health 2016, 4, 148. [CrossRef]

136. Burns, C.J.; McIntosh, L.J.; Mink, P.J.; Jurek, A.M.; Li, A.A. Pesticide exposure and neurodevelopmental outcomes: Review of the epidemiologic and animal studies. J. Toxicol. Environ. Health B Crit. Rev. 2013, 16, 127-283. [CrossRef]

137. Smith-Spangler, C.; Brandeau, M.L.; Hunter, G.E.; Clay Bavinger, J.; Pearson, M.; Eschbach, P.J.; Sundaram, V.; Liu, H.; Schirmer, P.; Stave, C.; et al. Are organic foods safer or healthier than conventional alternatives? A systematic review. Ann. Intern. Med. 2012, 157, 348-366. [CrossRef]

138. Hoefkens, C.; Vandekinderen, I.; De Meulenaer, B.; Devlieghere, F.; Baert, K.; Sioen, I.; De Henauw, S.; Verbeke, W.; Van Camp, J. A literature-based comparison of nutrient and contaminat contents between organic and conventional vegetables and potatoes. Brit. Food J. 2009, 1078-1097. [CrossRef]

139. Mie, A.; Andersen, H.R.; Gunnarsson, S.; Kahl, J.; Kesse-Guyot, E.; Rembiałkowska, E.; Quaglio, G.; Grandjean, P. Human health implications of organic food and organic agriculture: A comprehensive review. Environ. Health 2017, 16, 111. [CrossRef]

140. Wang, J.; Hasanalieva, G.; Wood, L.; Anagnostopoulos, C.; Ampadogiannis, G.; Bempelou, E.; Kiousi, M.; Markellou, E.; Iversen, P.O.; Seal, C.; et al. Effect of wheat species (Triticum aestivum vs T. spelta), farming system (organic vs conventional) and flour type (wholegrain vs white) on composition of wheat flour-Results of a retail survey in the UK and Germany-3. Pesticide residue content. Food Chem. X 2020, 6, 100089. [CrossRef]

141. Rempelos, L.; Wang, J.; Baranski, M.; Watson, A.; Volakakis, N.; Hoppe, H.-W.; Kühn-Velten, W.N.; Hadall, C.; Hasanaliyeva, G.; Chatzidimitriou, E.; et al. Diet and food type affect urinary pesticide residue excretion profiles in healthy individuals: Results of a randomized controlled dietary intervention trial. Am. J. Clin. Nutr. 2021, nqab308. [CrossRef] [PubMed]

142. Średnicka-Tober, D.; Baranski, M.; Gromadzka-Ostrowska, J.; Skwarło-Sońta, K.; Rembiałkowska, E.; Hajslova, J.; Schulzova, V.; Cakmak, I.; Ozturk, L.; Krolikowski, T.; et al. Effect of crop protection and fertilization regimes used in organic and conventional production systems on feed composition and selected physiological parameters in rats. J. Agric. Food Chem. 2013, 61, 1017-1029. [CrossRef] [PubMed]

143. Baranski, M.; Średnicka-Tober, D.; Rempelos, L.; Hasanaliyeva, G.; Gromadzka-Ostrowska, J.; Skwarło-Sońta, K.; Królikowski, T.; Rembiałkowska, E.; Hajslova, J.; Schulzova, V.; et al. Feed Composition Differences Resulting from Organic and Conventional Farming Practices Affect Physiological Parameters in Wistar Rats-Results from a Factorial, Two-Generation Dietary Intervention Trial. Nutrients 2021, 13, 377. [CrossRef]

144. Rahman, A. Effect of soil organic matter on the phytotoxicity of soil applied herbicides-Glasshouse studies. N. Z. J. Exp. Agric. 1976, 4, 85-88. [CrossRef]

145. Jones, R.L.; Norris, F.A. Factors affecting degradation of aldicarb and ethoprop. J. Nematol. 1998, 30, 45-55. [PubMed]

146. Kirchmann, H.; Haberhauer, G.; Kandeler, E.; Sessitsch, A.; Gerzabek, M.H. Effects of level and quality of organic matter input on carbon storage and biological activity in soil: Synthesis of a long-term experiment. Global Biogeochem. Cycles 2004, 18, GB4011. [CrossRef]

147. Lori, M.; Symnaczik, S.; Mader, P.; De Deyn, G.; Gattinger, A. Organic farming enhances soil microbial abundance and activity-A meta-analysis and meta-regression. PLoS ONE 2017, 12, 0180442. [CrossRef]

148. Harkes, P.; Suleiman, A.K.A.; van den Elsen, S.J.J.; de Haan, J.J.; Holterman, M.; Kuramae, E.; Helder, J. Conventional and organic soil management as divergent drivers of resident and active fractions of major soil food web constituents. Sci. Rep. 2019, 9, 13521. [CrossRef] [PubMed]

149. Saladin, G.; Clément, C. Physiological side effects of pesticides on non-target plants. In Agriculture and Soil Pollution; Livingston, J.V., Ed.; Nova Science Publishers Inc.: Hauppauge, NY, USA, 2005; pp. 53-86.

150. McCurdy, J.D.; McElroy, J.S.; Kopsell, D.A.; Sams, C.E.; Sorochan, J.C. Effects of Mesotrione on Perennial Ryegrass (Lolium perenne L.) Carotenoid Concentrations under Varying Environmental Conditions. J. Agric. Food Chem. 2008, 56, 9133-9139. [CrossRef]

151. Marcelo, P.; Gomes, E.; Smedbol, A.; Chalifour, L.; Hénault-Ethier, M.; Labrecque, L.; Lepage, M.; Lucotte, P.J. Alteration of plant physiology by glyphosate and its by-product aminomethylphosphonic acid: An overview. J. Exp. Bot. 2014, 65, 4691-4703. [CrossRef]

152. Kanissery, R.; Gairhe, B.; Kadyampakeni, D.; Batuman, O.; Alferez, F. Glyphosate: Its Environmental Persistence and Impact on Crop Health and Nutrition. Plants 2019, 8, 499. [CrossRef]

153. Cakmak, I.; Yazici, A.; Tutus, Y.; Ozturk, L. Glyphosate reduced seed and leaf concentrations of calcium, manganese, magnesium, and iron in non-glyphosate resistant soybean. Eur. J. Agron. 2009, 31, 114-119. [CrossRef]

154. Bott, S.; Tesfamariam, T.; Candan, H.; Cakmak, I.; Römheld, V.; Neumann, G. Glyphosate-induced impairment of plant growth and micronutrient status in glyphosate-resistant soybean (Glycine max L.). Plant Soil 2008, 312, 185-194. [CrossRef] 
155. Martinez, D.A.; Loening, U.E.; Graham, M.C. Impacts of glyphosate-based herbicides on disease resistance and health of crops: A review. Environ. Sci. Eur. 2018, 30, 2. [CrossRef] [PubMed]

156. Lammerts van Bueren, E.T.; Thorup-Kristensen, K.; Leifert, C.; Cooper, J.M.; Becker, H.C. Breeding for nitrogen efficiency; concepts, methods, and case studies. Euphytica 2014, 199, 1-2. [CrossRef]

157. Nuijten, E.; Messmer, M.M.; Lammerts van Bueren, E.T. Concepts and Strategies of Organic Plant Breeding in Light of Novel Breeding Techniques. Sustainability 2017, 9, 18. [CrossRef]

158. Lammerts van Bueren, E.T.; Myers, J.R. Organic Crop Breeding; Wiley-Blackwell: Hoboken, NY, USA, 2012.

159. Armesto, J.; Rocchetti, G.; Senizza, B.; Pateiro, M.; Rubén Domínguez, F.J.B.; Lucini, L.; Lorenzo, J.L. Nutritional characterization of Butternut squash (Cucurbita moschata D.): Effect of variety (Ariel vs. Pluto) and farming type (conventional vs. organic). Food Res. Int. 2020, 132, 109052. [CrossRef] [PubMed]

160. Hornick, S.B. Factors affecting the nutritional quality of crops. Am. J. Altern. Agric. 1992, 7, 63-68. [CrossRef]

161. EU. Commission Regulation (EC) No 396/2005 of the European Parliament and of the Council of 23 February 2005 on Maximum Residue Levels of Pesticides in or on Food and Feed of Plant and Animal Origin and Amending Council Directive 91/414/EEC. 2005. Available online: https:/ / eur-lex.europa.eu/legal-content/EN/TXT/PDF/?uri=CELEX:32005R0396\&from=EN (accessed on 4 December 2021).

162. EU. Commission Regulation (EC) No 1881/2006 of 19 December 2006 setting maximum levels for certain contaminants in foodstuffs. Off. J. Eur. Legis. 2006, 364, 5-24.

163. Jones, J.M.; Engleson, J. Whole Grains: Benefits and Challenges. Annu. Rev. Food Sci. Technol. 2010, 1, 19-40. [CrossRef] [PubMed]

164. Tennent, D.R.; Davidson, J.; Day, A.J. Phytonutrient intakes in relation to European fruit and vegetable consumption patterns observed in different food surveys. Brit. J. Nutr. 2014, 112, 1214-1225. [CrossRef]

165. Martinez, M.A.; Martin-Calvo, N. Mediterranean diet and life expectancy; beyond olive oil, fruits and vegetables. Curr. Opin. Clin. Nutr. Metab. Care 2016, 19, 401-407. [CrossRef] [PubMed]

166. European Commission. European Commission Health Promotion and Disease Prevention Knowledge Gateway 2021. Available online: https: / / ec.europa.eu/jrc/en/health-knowledge-gateway (accessed on 1 March 2021).

167. Castro-Quezada, I.; Román-Viňas, B.; Serra-Majem, L. The Mediterranean diet and nutritional adequacy: A review. Nutrients 2014, 6, 231-248. [CrossRef]

168. Baranski, M.; Rempelos, L.; Iversen, P.O.; Leifert, C. Effects of organic food consumption on human health; The jury is still out. Food Nutr. Res. 2017, 61, 1287333. [CrossRef]

169. Vigar, V.; Myers, S.; Oliver, C.; Arellano, J.; Robinson, S.; Leifert, C. A Systematic Review of Organic Versus Conventional Food Consumption: Is There a Measurable Benefit on Human Health? Nutrients 2020, 12, 7. [CrossRef]

170. Velimirov, A.; Huber, M.; Lauridsen, C.; Rembialkowska, E.; Seidel, K.; Bugel, S. Feeding trials in organic food quality and health research. J. Sci. Food Agric. 2010, 90, 175-182. [CrossRef]

171. Koletzko, B.; Godfrey, K.M.; Poston, L.; Szajewska, H.; van Goudoever, J.B.; de Waard, M.; Brands, B.; Grivell, R.M.; Deussen, A.R.; Dodd, J.M.; et al. Nutrition During Pregnancy, Lactation and Early Childhood and its Implications for Maternal and Long-Term Child Health: The Early Nutrition Project Recommendations. Ann. Nutr. Metab. 2019, 74, 93-106. [CrossRef]

172. Yong, S.-B.; Wu, C.C.; Wang, L.; Yang, K. Influence and mechanisms of maternal and infant diets on the development of childhood asthma. Pediatr. Neonatol. 2013, 54, 5-11. [CrossRef] [PubMed]

173. Bishop, K.S.; Ferguson, L.R. The interaction between epigenetics, nutrition and the development of cancer. Nutrients 2015, 7, 922-948. [CrossRef] [PubMed]

174. Topart, C.; Werner, E.; Arimondo, P.B. Wandering along the epigenetic timeline. Clin. Epigenetics 2020, 12, 97. [CrossRef]

175. Choi, S.-W.; Friso, S. Epigenetics: A new bridge between nutrition and health. Adv. Nutr. 2010, 1, 8-16. [CrossRef]

176. Tryndyak, V.P.; Ross, S.A.; Beland, F.A.; Pogribny, I.P. Down-regulation of the microRNAs miR-34a, miR-127, and miR-200b in rat liver during hepatocarcinogenesis induced by a methyl-deficient diet. Mol. Carcinog. 2009, 48, 479-487. [CrossRef] [PubMed]

177. Gerhauser, C. Impact of dietary gut microbial metabolites on the epigenome. Philos. Trans. R. Soc. Lond. B Biol. Sci. 2018, 373, 20170359. [CrossRef] [PubMed]

178. Fang, M.; Chen, D.; Yang, C.S. Dietary polyphenols may affect DNA methylation. J. Nutr. 2007, 137, 223-228. [CrossRef]

179. Wang, L.-S.; Arnold, M.; Huang, Y.-W.; Sardo, C.; Seguin, C.; Martin, E.; Huang, T.H.-M.; Riedl, K.; Schwartz, S.; Frankel, W.; et al. Modulation of genetic and epigenetic biomarkers of colorectal cancer in humans by black raspberries: A phase I pilot study. Clin. Cancer Res. 2011, 17, 598-610. [CrossRef] [PubMed]

180. Pudenz, M.; Roth, K.; Gerhauser, C. Impact of soy isoflavones on the epigenome in cancer prevention. Nutrients 2014, 6, 4218-4272. [CrossRef]

181. Lascano, S.; Lopez, M.; Arimondo, P.B. Natural products and chemical biology tools: Alternatives to target epigenetic mechanisms in cancers. Chem. Rec. 2018, 18, 1854-1876. [CrossRef]

182. King, A.J.F. The use of animal models in diabetes research. Br. J. Pharmacol. 2012, 166, 877-894. [CrossRef]

183. Buettner, R.; Schölmerich, D.; Bollheimer, L.C. High-fat diets: Modelling the metabolic disorders of human obesity in rodents. Obesity 2007, 15, 798-808. [CrossRef]

184. Lutz, T.A.; Woods, S.C. Overview of animal models for obesity. Curr. Protoc. Pharmacol. 2012, 58, 5. [CrossRef]

185. Brantsæter, A.L.; Ydersbond, T.A.; Hoppin, J.A.; Haugen, M.; Meltzer, H.M. Organic Food in the Diet: Exposure and Health Implications. Annu. Rev. Public Health 2017, 38, 295-313. [CrossRef] [PubMed] 
186. Bradman, A.; Quirós-Alcalá, L.; Castorina, R.; Schall, E.A.; Camacho, J.; Holland, N.T.; Boyd Barr, D.; Eskenazi, B. Effect of organic diet intervention on pesticide exposures in young children living in low-income urban and agricultural communities. Environ. Health Perspect. 2015, 123, 1086-1093. [CrossRef]

187. Baudry, J.; Debrauwer, L.; Durand, G.; Limon, G.; Delcambre, A.; Vidal, R.; Taupier-Letage Hercberg, B.; Lairon, D.; Cravedi, J.-P.; Kesse-Guyot, E. Urinary pesticide concentrations in French adults with low and high organic food consumption: Results from the general population-based NutriNet-Santé study. J. Expo Sci. Environ. Epidemiol. 2019, 29, 366-378. [CrossRef]

188. Curl, C.L.; Porter, J.; Penwell, I.; Phinney, R.; Ospina, M.; Calafat, A.M. Effect of a 24-week randomized trial of an organic produce intervention on pyrethroid and organophosphate pesticide exposure among pregnant women. Environ. Int. 2019, $132,104957$. [CrossRef]

189. Fagan, J.; Bohlen, L.; Patton, S.; Klein, K. Organic diet intervention significantly reduces urinary glyphosate levels in U.S. Children and adults. Environ. Res. 2020, 189, 109898. [CrossRef]

190. Hyland, C.; Bradman, A.; Gerona, R.; Patton, S.; Zakharevich, I.; Guniera, R.B.; Klein, K. Organic diet intervention significantly reduces urinary pesticide levels in U.S. Children and adults. Environ. Res. 2019, 171, 568-575. [CrossRef]

191. Transparency Market Research. Organophosphate and Carbamate Poisoning Market_Global Industry Analysis, Size, Share, Growth, Trends and Forecast 2016-2024; Transparency Market Research: Albany, NY, USA, 2016; Available online: www. transparencymarketresearch.com/organophosphate-carbamate-poisoning-market.html (accessed on 12 June 2021).

192. Alavanja, M.C.R.; Hoppin, J.A.; Kamel, F. Health Effects of Chronic Pesticide Exposure: Cancer and Neurotoxicity. Annu. Rev. Public Health 2004, 25, 155-197. [CrossRef] [PubMed]

193. Hamilton, D.; Ambrus, A.; Dieterle, R.; Felsot, A.; Harris, C.; Petersen, B.; Racke, K.; Wong, S.-S.; Gonzalez, R.; Tanaka, K.; et al. Pesticide residues in food-Acute dietary exposure. Pest Manag. Sci. 2004, 60, 311-339. [CrossRef]

194. Winter, C.K. Chronic dietary exposure to pesticide residues in the United States. Int. J. Food Contam. 2015, 2, 11. [CrossRef]

195. Heindel, J.J.; von Saal, F.S. Role of nutrition and environmental endocrine disrupting chemicals during the prerinatal period on the aetiology of obesity. Mol. Cell. Endocrinol. 2009, 304, 90-96. [CrossRef]

196. Yang, O.; Kim, H.L.; Weon, J.I.; Seo, Y.R. Endocrine-disrupting chemicals: Review of toxicological mechanisms using molecular pathway analysis. J. Cancer Prev. 2015, 20, 12-24. [CrossRef] [PubMed]

197. Petrakis, D.; Vassilopoulou, L.; Mamoulakis, C.; Psycharakis, C.; Anifantaki, A.; Sifakis, S.; Docea, A.O.; Tsiaoussis, J.; Makrigiannakis, A.; Tsatsakis, A.M. Endocrine Disruptors Leading to Obesity and Related Diseases. Int. J. Environ. Res. Public Health 2017, 14, 1282. [CrossRef]

198. Xin, F.; Susiarjo, M.; Bartolomei, M.S. Multigenerational and transgenerational effects of endocrine disrupting chemicals: A role for altered epigenetic regulation? Semin. Cell Dev. Biol. 2015, 43, 66-75. [CrossRef] [PubMed]

199. Trasande, L.; Zoeller, R.T.; Hass, U.; Kortenkamp, A.; Grandjean, P.; Myers, J.P.; DiGangi, J.; Bellanger, M.; Hauser, R.; Legler, J.; et al. Estimating burden and disease costs of exposure to endocrine-disrupting chemicals in the European union. J. Clin. Endocrinol. Metab. 2015, 100, 1245-1255. [CrossRef] [PubMed]

200. Rijk, I.; Duursen, M.; van der Berg, M. Health Cost That May Be Associated with Endocrine Disrupting Chemicals; Institute for Risk Assessment Sciences, 2016; Available online: www.uu.nl/sites/default/files/rijk_et_al_2016_-_report_iras_-_health_cost_ associated_with_edcs_3.pdf (accessed on 4 December 2021).

201. Cuhra, M.; Bøhn, T.; Cuhra, P. Glyphosate: Too much of a good thing? Front. Environ. Sci. 2016, 4, 28. [CrossRef]

202. EU Pesticide Database. Available online: https://ec.europa.eu/food/plant/pesticides/eu-pesticides-database/public/?event= activesubstance.selection\&language $=\mathrm{EN}$ (accessed on 1 March 2021).

203. Mnif, W.; Ibn Hadj Hassine, A.; Bouaziz, A.; Bartegi, A.; Thomas, O.; Roig, B. Effect of Endocrine Disruptor Pesticides: A Review. Int. J. Environ. Res. Public Health 2011, 8, 2265-2303. [CrossRef]

204. Guyton, K.Z.; Loomis, D.; Grosse, Y.; El Ghissassi, F.; Benbrahim-Tallaa, L.; Guha, N.; Scoccianti, C.; Mattock, H.; Straif, K. Carcinogenicity of tetrachlorvinphos, parathion, malathion, diazinon, and glyphosate. Lancet Oncol. 2017, 16, 490-491. [CrossRef]

205. Antoniou, M.; Habib, M.E.M.; Howard, C.V.; Jennings, R.C.; Leifert, C.; Nodari, R.O.; Robinson, C.J.; Fagan, J. Teratogenic Effects of Glyphosate-Based Herbicides: Divergence of Regulatory Decisions from Scientific Evidence. J. Environ. Anal. Toxicol. 2013, S4, 006. [CrossRef]

206. Benbrook, C.M. How Did the US EPA and IARC reach diametrically opposed conclusions on the genotoxicity of glyphosate-based herbicides? Environ. Sci. Eur. 2019, 31, 2. [CrossRef]

207. Kesse-Guyot, E.; Baudry, J.; Assmann, K.E.; Galan, P.; Hercberg, S.; Lairon, D. Prospective association between consumption frequency of organic food and body weight change, risk of overweight or obesity: Results from the NutriNet-Santé Study. Br. J. Nutr. 2017, 117, 325-334. [CrossRef]

208. Baudry, J.; Lelong, H.; Adriouch, S.; Julia, C.; Allès, B.; Hercberg, S.; Touvier, M.; Lairon, D.; Galan, P.; Kesse-Guyot, E. Association between organic food consumption and metabolic syndrome: Cross-sectional results from the NutriNet-Santé study. Eur. J. Nutr. 2018, 57, 2477-2488. [CrossRef]

209. Bradbury, K.E.; Balkwill, A.; Spencer, E.A.; Roddam, A.W.; Reeves, G.K.; Green, J.; Key, T.J.; Beral, V.; Pirie, K. Organic food consumption and the incidence of cancer in a large prospective study of women in the United Kingdom. Br. J. Cancer 2014, 110, 2321-2326. [CrossRef] 
210. Baudry, J.; Assmann, K.E.; Touvier, M.; Allès, B.; Seconda, L.; Latino-Martel, P.; Ezzedine, K.; Galan, P.; Hercberg, S.; Lairon, D.; et al. Association of frequency of organic food consumption with cancer risk: Findings from the nutrinet-santé prospective cohort study. JAMA Intern. Med. 2018, 178, 1597-1606. [CrossRef] [PubMed]

211. Brantsæter, A.L.; Torjusen, H.; Meltzer, H.M.; Papadopoulou, E.; Hoppin, J.A.; Alexander, J.; Lieblein, G.; Roos, G.; Holten, J.M.; Swartz, J.; et al. Organic food consumption during pregnancy and hypospadias and cryptorchidism at birth: The Norwegian Mother and Child Cohort Study (MoBa). Environ. Health Perspect. 2016, 124, 357-364. [CrossRef] [PubMed]

212. Christensen, J.S.; Asklund, C.; Skakkebaek, N.E.; Jorgensen, N.; Andersen, H.R.; Jorgensen, T.M.; Olsen, L.H.; Hoyer, A.P.; Moesgaard, J.; Thorup, J.; et al. Association between organic dietary choice during pregnancy and hypospadias in offspring: A study of mothers of 306 boys operated on for hypospadias. J. Urol. 2013, 189, 1077-1082. [CrossRef]

213. Torjusen, H.; Brantsæter, A.L.; Haugen, M.; Alexander, J.; Bakketeig, L.S.; Lieblein, G.; Stigum, H.; Næs, T.; Swartz, J.; HolmboeOttesen, G.; et al. Reduced risk of pre-eclampsia with organic vegetable consumption: Results from the prospective Norwegian Mother and Child Cohort Study. BMJ Open 2014, 4, 6143. [CrossRef] [PubMed]

214. Kummeling, I.; Thijs, C.; Huber, M.; van de Vijver, L.P.L.; Snijders, B.E.P.; Penders, J.; Stelma, F.; van Ree, R.; van den Brandt, P.A.; Dagnelie, P.C. Consumption of organic foods and risk of atopic disease during the first 2 years of life in the Netherlands. $\mathrm{Br}$. J. Nutr. 2008, 99, 598-605. [CrossRef]

215. Buscail, C.; Chevrier, C.; Serrano, T.; Pele, F.; Monfort, C.; Cordier, S.; Viel, J.F. Prenatal pesticide exposure and otitis media during early childhood in the PELAGIE mother-child cohort. Occup. Environ. Med. 2015, 72, 837-844. [CrossRef]

216. Chiu, Y.H.; Afeiche, M.C.; Gaskins, A.J.; Williams, P.L.; Petrozza, J.C.; Tanrikut, C.; Hauser, R.; Chavarro, J.E. Fruit and vegetable intake and their pesticide residues in relation to semen quality among men from a fertility clinic. Hum. Reprod. 2015, 30, 1342-1351. [CrossRef] [PubMed]

217. Chiu, Y.H.; Williams, P.L.; Gillman, M.W.; Gaskins, A.J.; Minguez-Alarcon, L.; Souter, I.; Toth, T.L.; Ford, J.B.; Hauser, R.; Chavarro, J.E.; et al. Association between pesticide residue intake from consumption of fruits and vegetables and pregnancy outcomes among women undergoing infertility treatment with assisted reproductive technology. JAMA Intern. Med. 2018, 178, 17-26. [CrossRef]

218. Rebouillat, P.; Vidal, R.; Cravedi, J.-P.; Taupier-Letage, B.; Debrauwer, L.; Gamet-Payrastre, L.; Touvier, M.; Deschasaux-Tanguy, M.; Latino-Martel, P.; Hercberg, S.; et al. Prospective association between dietary pesticide exposure profiles and postmenopausal breast-cancer risk in the NutriNet-Santé cohort. Int. J. Epidemiol. 2021, dyab015. [CrossRef]

219. Baudry, J.; Méjean, C.; Péneau, S.; Galan, P.; Hercberg, S.; Lairon, D.; Kesse-Guyot, E. Health and dietary traits of organic food consumers: Results from the NutriNet-Santé study. Br. J. Nutr. 2015, 114, 2064-2073. [CrossRef]

220. Eisinger-Watzl, M.; Wittig, F.; Heuer, T.; Hoffmann, I. Customers Purchasing Organic Food-Do They Live Healthier? Results of the German National Nutrition Survey II. Eur. J. Nutr. Food Saf. 2015, 5, 59-71. [CrossRef]

221. Cordain, L.; Eaton, S.B.; Sebastian, A.; Mann, N.; Lindeberg, S.; Watkins, B.A.; O’Keefe, J.H.; Brand-Miller, J. Origins and evolution of the Western diet: Health implications for the 21st century. Am. J. Clin. Nutr. 2005, 81, 341-354. [CrossRef] [PubMed]

222. Średnicka-Tober, D.; Baranski, M.; Seal, C.J.; Sanderson, R.; Benbrook, C.; Steinshamn, H.; Gromadzka-Ostrowska, J.; Rembiałkowska, E.; Skwarło-Sońta, K.; Eyre, M.; et al. Higher PUFA and omega-3 PUFA, CLA, $\alpha$-tocopherol and iron, but lower iodine and selenium concentrations in organic milk: A Systematic Literature Review and Meta- and Redundancy Analyses. Br. J. Nutr. 2016, 115, 1043-1060. [CrossRef] [PubMed]

223. McKnight, G.M.; Duncan, C.W.; Leifert, C.; Golden, M.H.N. Dietary Nitrate in Man—Friend or foe? Brit. J. Nutr. 1999, 81, 349-358. [CrossRef]

224. Duncan, C.; Li, H.; Dykhuizen, R.; Frazer, R.; Johnston, P.; MacKnight, G.; Smith, L.; Lamza, K.; McKenzie, H.; Batt, L.; et al. Protection against oral and gastrointestinal diseases: The importance of dietary nitrate intake, oral nitrate reduction and enterosalivary nitrate circulation. Comp. Biochem. Physiol. Part A Mol. Integr. Physiol. 1997, 118, 939-948. [CrossRef]

225. Dykhuizen, R.; Frazer, A.; MacKenzie, H.; Golden, M.; Leifert, C.; Benjamin, N. Helicobacter pylori is killed by nitrite under acidic conditions. Gut 1998, 42, 334-337. [CrossRef]

226. Weitzberg, E.; Lundberg, J.O. Novel aspects of dietary nitrate and human health. Annu. Rev. Nutr. 2013, 33, 129-159. [CrossRef] [PubMed]

227. Chiu, Y.-H.; Sandoval-Insausti, H.; Ley, S.H.; Bhupathiraju, S.N.; Hauser, R.; Rimm, E.B.; Manson, J.E.; Sun, Q.; Chavarroa, J.E. Association between intake of fruits and vegetables by pesticide residue status and coronary heart disease risk. Environ. Int. 2019, 132, 105113. [CrossRef]

228. Herrero, M.; Wirsenius, S.; Henderson, B.; Rigolot, C.; Thornton, P.; Havlík, P.; de Boer, I.; Gerber, P. Livestock and the environment: What have we learned in the past decade? Annu. Rev. Environ. Resour. 2015, 40, 177-202. [CrossRef]

229. Shepon, A.; Eshel, G.; Noor, E.; Milo, R. Energy and protein feed-to-food conversion efficiencies in the US and potential food security gains from dietary changes. Environ. Res. Lett. 2016, 11, 105002. [CrossRef]

230. OECD. OECD-FAO Agricultural Outlook 2013. Available online: www.oecd-ilibrary.org/agriculture-and-food/oecd-faoagricultural-outlook-2013_agr_outlook-2013-en (accessed on 4 December 2021).

231. FAO. Handbook of Agricultural Cost of Production Statistics; Food and Agriculture Organisation of the United Nations: Rome, Italy, 2016; Available online: http:/ / www.fao.org/3/ca6411en/ca6411en.pdf (accessed on 3 June 2021).

232. Agnolucci, P.; De Lipsis, V. Long-run trend in agricultural yield and climatic factors in Europe. Clim. Chang. 2020, 159, 385-405. [CrossRef] 
233. Schauberger, B.; Ben-Ari, T.; Makowski, D.; Kato, T.; Kato, H.; Ciais, P. Yield trends, variability and stagnation analysis of major crops in France over more than a century. Sci. Rep. 2018, 8, 16865. [CrossRef] [PubMed]

234. van der Ploeg, R.R.; Böhm, W.; Kirkham, M.B. On the origin of the theory of mineral nutrition of plants and the "Law of the Minimum". Soil Sci. Soc. Am. J. 1999, 63, 1055-1062. [CrossRef]

235. Heckman, J. A history of organic farming: Transitions from Sir Albert Howard's War in the Soil to USDA National Organic Program. Renew. Agric. Food Syst. 2006, 21, 143-150. [CrossRef]

236. Verbruggen, E.; Röling, W.F.M.; Gamper, H.A.; Kowalchuk, G.A.; Verhoef, H.A.; van der Heijden, M.G.A. Positive effects of organic farming on below-ground mutualists: Large-scale comparison of mycorrhizal fungal communities in agricultural soil. New Phytol. 2010, 186, 968-979. [CrossRef] [PubMed]

237. Tuomisto, H.L.; Hodge, I.D.; Riordan, P.; Macdonald, D.W. Does organic farming reduce environmental impacts?-A metaanalysis of European research. J. Environ. Manag. 2012, 112, 309-320. [CrossRef] [PubMed]

238. Gabriel, D.; Sait, S.M.; Hodgson, J.A.; Schmutz, U.; Kumin, W.E.; Benton, T.G. Scale matters: The impact of organic farming on biodiversityat different spatial scales. Ecol. Let. 2010, 13, 858-869. [CrossRef]

239. Lee, K.S.; Choe, Y.C.; Park, S.H. Measuring the environmental effects of organic farming: A meta-analysis of structural variables in empirical research. J. Environ. Manag. 2015, 162, 263-274. [CrossRef] [PubMed]

240. Mondelaers, K.; Aertsens, J.; Van Huylenbroeck, G. A meta-analysis of the differences in environmental impacts between organic and conventional farming. Br. Food J. 2009, 111, 1098-1119. [CrossRef]

241. Mie, A.; Kesse-Guyot, E.; Kahl, J.; Rembiałkowska, E.; Andersen, H.R.; Grandjean, P.; Gunnarsson, S. Human Health Implications of Organic Food and Organic Agriculture; European Parliamentary Research Services, Scientific Foresight Unit (STOA): Brussels, Belgium, 2016; Available online: www.europarl.europa.eu/RegData/etudes/STUD/2016/581922/EPRS_STU(2016)581922_EN. pdf (accessed on 3 June 2021).

242. Voutzourakis, N.; Stefanakis, A.; Stergiadis, S.; Rempelos, L.; Tzanidakis, N.; Eyre, M.; Butler, G.; Leifert, C.; Sotiraki, S. Effect of intensification practices, lambing period and environmental parameters on animal health, and milk yield and quality in dairy sheep production systems on Crete. Sustainability 2021, 13, 9706. [CrossRef]

243. Voutzourakis, N.; Tzanidakis, N.; Stergiadis, S.; Rempelos, L.; Eyre, M.; Atsali, I.; Franceschin, E.; Leifert, C.; Stefanakis, A.; Sotiraki, S.; et al. Sustainable Intensification? Increased Production Diminishes Omega-3 Content of Sheep Milk. Sustainability 2020, 12, 1228. [CrossRef]

244. Davis, H.; Chatzidimitriou, E.; Leifert, C.; Butler, G. Evidence that forage-fed cows can enhance milk quality. Sustainability 2020, 12, 3688. [CrossRef]

245. Benbrook, C.M.; Davis, D.R.; Heins, B.J.; Latif, M.A.; Leifert, C.; Peterman, L.; Butler, G.; Faergerman, O.; Abel-Caines, S.; Baranski, M. Enhancing the fatty acid profile of milk through forage-based rations, with nutrition modeling of diet outcomes. Food Sci. Nutr. 2018, 6, 681-700. [CrossRef] [PubMed]

246. Średnicka-Tober, D.; Marcin Barański, M.; Seal, C.J.; Sanderson, R.; Benbrook, C.; Steinshamn, H.; Gromadzka-Ostrowska, J.; Rembiałkowska, E.; Skwarło-Sońta, K.; Eyre, M.; et al. Composition differences between organic and conventional meat; A systematic literature review and meta-analysis. Br. J. Nutr. 2016, 115, 994-1011. [CrossRef] [PubMed]

247. Stergiades, S.; Leifert, C.; Seal, C.J.; Eyre, M.D.; Larsen, M.K.; Slots, T.; Nielsen, J.H.; Butler, G. A 2-year study on milk quality from three pasture-based dairy systems of contrasting production intensities in Wales. J. Agric. Sci. 2015, 153, 708-731. [CrossRef]

248. Stergiadis, S.; Leifert, C.; Seal, C.J.; Eyre, M.D.; Nielsen, J.H.; Larsen, M.K.; Slots, T.; Steinshamn, H.; Butler, G. Effect of feeding intensity and milking systems on nutritionally relevant milk components in dairy farming systems in the north east of England. $J$. Agric. Food Chem. 2012, 60, 7270-7281. [CrossRef]

249. Butler, G.; Nielsen, J.H.; Larsen, M.L.; Rehberger, B.; Stergiadis, S.; Canever, A.; Leifert, C. The effects of dairy management and processing on quality characteristics of milk and dairy products. NJAS-Wagen. J. Life Sci. 2011, 58, 97-102. [CrossRef]

250. Butler, G.; Collomb, M.; Rehberger, B.; Sanderson, R.; Eyre, M.; Leifert, C. CLA isomer concentrations in milk from high and low-input management dairy systems. J. Sci. Food Agric. 2009, 89, 697-705. [CrossRef]

251. Butler, G.; Nielsen, J.H.; Slots, T.; Seal, C.; Eyre, M.D.; Sanderson, R.; Leifert, C. Fatty acid and fat soluble antioxidant concentrations in milk from high and low input conventional and organic systems; seasonal variation. J. Sci. Food Agric. 2008, 88, $1431-1441$. [CrossRef]

252. Gilling-Ulph, M. Can you Boost Your Fertility by Eating Organic Food; The Augora Clinic: Brighton \& Hove, UK, 2019; Available online: https: / / agoraclinic.co.uk/ fertility-organic-food (accessed on 10 November 2021).

253. Jensen, T.K.; Giwercman, A.; Carlsen, E.; Scheike, T.; Skakkebaek, N.E. Semen quality among members of organic food associations in Zealand, Denmark. Lancet 1996, 347, 1844. [CrossRef]

254. Gundala, R.R.; Singh, A. What motivates consumers to buy organic foods? Results of an empirical study in the United States. PLoS ONE 2021, 16, e0257288. [CrossRef] [PubMed]

255. FAO. Why is Organic Food More Expensive Than Conventional Food. Available online: www.fao.org/organicag/oa-faq/oa-faq5 / en / (accessed on 10 November 2021).

256. IFOAM. Organic in Europe. Prospects \& Developments for Organic in National CAP Strategic Plans. 2021. Available online: https: //www.organicseurope.bio/content/uploads/2021/06/ifoameu_advocacy_CAP_StrategicPlansAnd25Target_202106.pdf?dd (accessed on 10 November 2021). 
257. EC. Communication from the commission to the European Parliament, the council, the European Economic and Social Committee and the Committee of the Regions on an Action Plan for the Development of Organic Farming, SWD(2021) 65 Final. 2021. Available online: https:/ / ec.europa.eu/info/sites/default/files/food-farming-fisheries/farming/documents/com2021_141_ act_organic-action-plan_en.pdf (accessed on 4 December 2021).

258. McNair, K. Organic Food is More Expensive, but Conventional Prices are Catching Up. Magnify. Money. 2021. Available online: www.magnifymoney.com/blog/news/organic-vs-conventional-food-study (accessed on 10 November 2021). 